$$
\text { UNIVERSIDADE DE SÃO PAULO }
$$

FACULDADE DE FILOSOFIA, LETRAS E CIÊNCIAS HUMANAS DEPARTAMENTO DE LETRAS MODERNAS

PROGRAMA DE PÓS-GRADUAÇÃO EM ESTUDOS LINGUÍSTICOS,

LITERÁRIOS E TRADUTOLÓGICOS EM FRANCÊS

Flávio Luís Soares de Barros

\title{
Labirinto de espelhos
}

Dispositivos e configurações do impasse

em Bouvard e Pécuchet, de Gustave Flaubert 


\author{
UNIVERSIDADE DE SÃO PAULO \\ FACULDADE DE FILOSOFIA, LETRAS E CIÊNCIAS HUMANAS \\ DEPARTAMENTO DE LETRAS MODERNAS \\ PROGRAMA DE PÓS-GRADUAÇÃO EM ESTUDOS LINGUÍSTICOS, \\ LITERÁRIOS E TRADUTOLÓGICOS EM FRANCÊS
}

\title{
Labirinto de espelhos \\ Dispositivos e configurações do impasse \\ em Bouvard e Pécuchet, de Gustave Flaubert
}

Flávio Luís Soares de Barros

\begin{abstract}
Dissertação apresentada ao Departamento de Letras Modernas da Faculdade de Filosofia, Letras e Ciências Humanas da Universidade de São Paulo para obtenção do título de Mestre em Letras

Área de concentração: Literatura Francesa
\end{abstract}

Orientadora: Prof. ${ }^{\text {a }}$ Dra Verónica Galíndez-Jorge

São Paulo

2011 


\section{AUTORIZADA A REPRODUÇÃO E DIVULGAÇÃO TOTAL OU PARCIAL DESTE TRABALHO, POR QUALQUER MEIO CONVENCIONAL OU ELETRÔNICO, PARA FINS DE ESTUDO E PESQUISA, DESDE QUE CITADA A FONTE.}

Catalogação da Publicação

Faculdade de Filosofia, Letras e Ciências Humanas

Universidade de São Paulo

BARROS, Flávio L. S. de

Labirinto de espelhos: dispositivos e configurações do impasse em Bouvard e Pécuchet, de Gustave Flaubert/ Flávio Luís Soares de Barros; orientadora: Verónica Galíndez-Jorge - São Paulo, 2011.

Dissertação (Mestrado - Programa de Estudos Linguísticos, Literários e Tradutológicos em Francês) Faculdade de Filosofia, Letras e Ciências Humanas - Universidade de São Paulo

1. Gustave Flaubert. 2. Romance Francês. 3. Labirinto. 4. Impasse. 5. Modernidade. 
BARROS, Flávio L. S. de

Título: Labirinto de espelhos: dispositivos e configurações do impasse em Bouvard e Pécuchet, de Gustave Flaubert

Dissertação apresentada ao Departamento de Letras Modernas da Faculdade de Filosofia, Letras e Ciências Humanas da Universidade de São Paulo para obtenção do grau de mestre em Letras

Aprovado em:

BANCA EXAMINADORA

Prof. Dr.

Instituição

Julgamento:

Assinatura

Prof. Dr.

Instituição

Julgamento:

Assinatura

Prof. Dr.

Instituição

Julgamento:

Assinatura 


\section{Sumário}

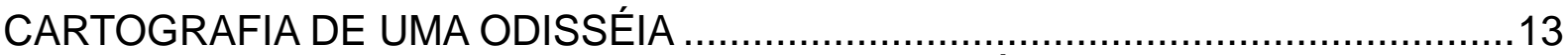

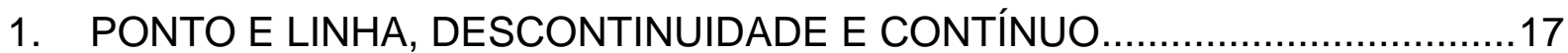

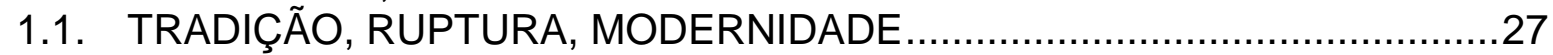

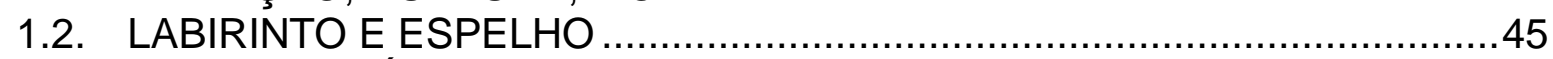

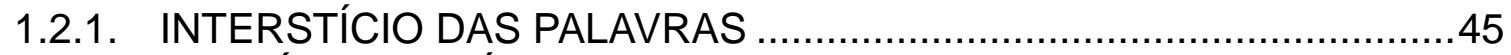

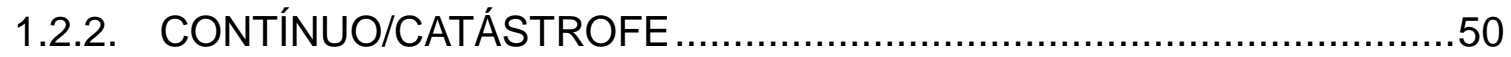

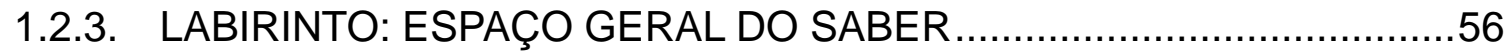

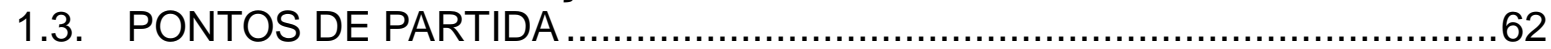

1.3.1. OS HOMENS E SEUS DUPLOS - LABIRINTO NA NARRATIVA ..........62

2. DISPOSITIVOS E CONFIGURAÇÕES DO IMPASSE .................................68

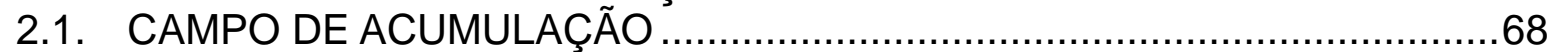

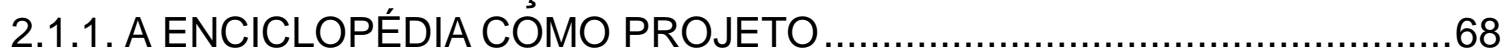

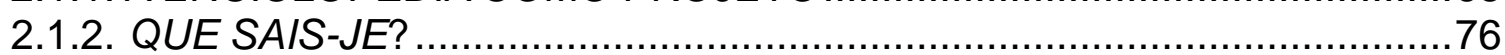

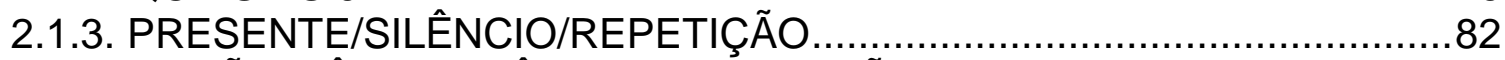

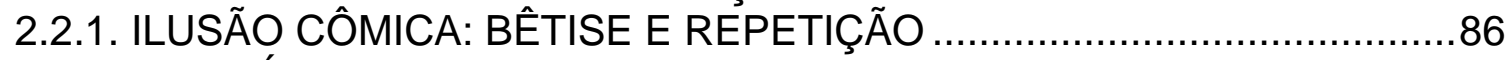

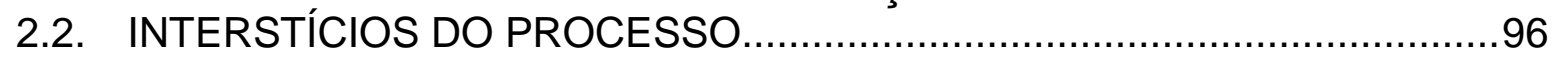

2.3. MODERNIDADE COMO LABIRINTO ………..............................104

2.4.1. IMPASSE E LABIRINTO …................................................... 104

2.4.2. BERMAN, FOUCAULT, PERRY ANDERSON: SINTOMAS DA

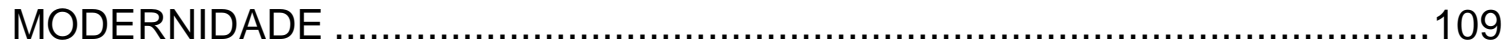

3. LINHA E PLANO: DESCONTINUIDADE E SABER …...............................115

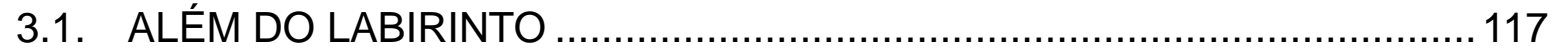

3.1.1. QUESTÕES DE POÉTICA E ESTÉTICA …......................................... 117

3.1.2 IL N'Y A PERSONNE ET IL Y A QUELQU'UN ....................................125

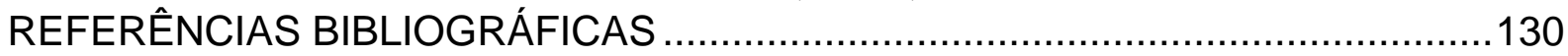


Dedico este trabalho às mulheres de minha vida. 


\section{AGRADECIMENTOS}

Agradeço o apoio terno, doce e constante de Lahyrde. That's my girl right here!

Agradeço a Antônio Carlos (in memoriam), por ter indicado o caminho da discordância.

Agradeço a Kitty, Lala e Bebé, pelo apoio, mesmo quando silencioso, e pela compreensão, ao longo de tanto tempo e de tanta ausência. Jeg elsker jer! (incondicionalmente!)

Agradeço à Prof. ${ }^{a}$ Dr ${ }^{a}$ Verónica Galindez-Jorge, éblouissante (au figuré), como dois mil fogos de artifício, pelo carinho e pela aceitação das idiossincrasias de um promeneur que se quis solitário ao longo da maior parte do percurso.

Agradeço aos colegas do Grupo de Estudos de Literatura, Loucura e Escritura-GELLE, pelos comentários e discussões, além, é claro, da paciência com que suportaram, bravamente, meu palavrório fragmentado. Agradeço de forma especial a Lúcia Ribeiro, pela suavidade inspiradora.

Agradeço a CAPES, pela bolsa concedida na fase final de elaboração do trabalho.

Agradeço ao pessoal da secretaria do Departamento de Línguas Modernas, pela orientação sempre eficaz no trato com o emaranhado da burocracia acadêmica.

Finalmente, agradeço a todos aqueles que, de alguma forma, contribuíram para que este trabalho chegasse ao seu termo, sem que isso signifique que a saída do labirinto tenha sido encontrada. Indulgentiam quaeso. 
Littérature: Occupation des oisifs 


\section{RESUMO}

BARROS, Flávio Luís Soares de. Labirinto de Espelhos: dispositivos e configurações do impasse em Bouvard e Pécuchet, de Gustave Flaubert. 2011. 136 p. Dissertação (Mestrado) - Faculdade de Filosofia, Letras e Ciências Humanas, Universidade de São Paulo, São Paulo, 2011.

A impossibilidade de decidir é apresentada ao leitor em Bouvard e Pécuchet, de Gustave Flaubert, sob diversos aspectos, evidenciando a reiteração da ideia de impasse, entendido como situação que atinge pontos de solução difícil ou aparentemente impossível. Associados à narrativa, à leitura, enquanto ato, e à escrita, enquanto processo, os impasses sucessivos aproximam-se do conceito de labirinto, colocando em movimento permanências e rupturas de vertente literária fecunda, descrita por Hugh Kenner em The Stoic Comedians. Abrindo espaço para a presença de opiniões contraditórias e, mais que isso, para a dificuldade de sua reconciliação, é sugerida uma quebra da lógica causal, numa narrativa não mais fundada em eventos, mas no tratamento do material linguístico. Abordam-se aqui reflexões teóricas sobre o funcionamento e os efeitos do texto estudado, levando em conta os questionamentos recentes sobre os paradoxos da fiç̧ão e os limites da narrativa, tomando por base um enfoque múltiplo. A bêtise, o aspecto enciclopédico do texto, a cópia e a comicidade servem como pontos de partida, com base na ótica da mobilização de saberes. Finalmente, são traçados paralelos entre procedimentos do texto flaubertiano e alguns procedimentos adotados desde o final do século $19 \mathrm{e}$ ao longo do século 20 por artistas de várias formas de expressão, buscando estabelecer possíveis diálogos.

PALAVRAS-CHAVE: GUSTAVE FLAUBERT, ROMANCE FRANCÊS, LABIRINTO, IMPASSE, MODERNIDADE. 


\begin{abstract}
BARROS, Flávio Luís Soares de. Mirror Labyrinth - devices and configurations of the impasse in Bouvard and Pécuchet, by Gustave Flaubert. 2011. 136 p. Master's dissertation - Faculty of Philosophy, Literature and Human Sciences, University of São Paulo, São Paulo, 2011.
\end{abstract}

The impossibility of deciding (undecidability) is presented to the reader in Bouvard and Pécuchet, by Gustave Flaubert, from different perspectives, evidencing the repetition of the idea of impasse, understood as a situation that has a difficult or seemingly impossible solution. Associated to the narrative, the reading act, and the writing process, the successive impasses relate to the concept of labyrinth, setting in motion continuities and ruptures of a rich literary lineage, described by Hugh Kenner in The Stoic Comedians. While allowing conflicting opinions to coexist and, more than that, allowing for the difficulty of their reconciliation, disruption of causal logic is suggested, resulting in a narrative no longer based on events, but in the treatment of linguistic material. Theoretical considerations on the functioning and the effects of the text studied are addressed, taking into account the recent reflections about the paradoxes of fiction and the limits of narrative, from a manifold perspective. The starting points are the bêtise, the encyclopedic character, Copy and the comic aspect of the novel, always having the use of knowledge as focal point. Finally, parallels between flaubertian procedures and some procedures adopted since the late 19th century and throughout the 20th century by artists of various forms of expression are drawn, seeking to establish possible dialogues.

KEYWORDS: GUSTAVE FLAUBERT, FRENCH NOVEL, LABYRINTH, IMPASSE, MODERNITY. 


\section{RESUMÉ}

BARROS, Flávio Luís Soares de. Labyrinthe des miroirs - configurations et dispositifs de l'impasse. 2011. 136 p. Mémoire de maîtrise. Faculté de Philosophie, Lettres et Sciences Humaines, Université de São Paulo, São Paulo, 2011.

L'impossibilité de décider est présentée au lecteur en Bouvard et Pécuchet, de Gustave Flaubert, sous plusieurs aspects, en mettant l'accent sur la répétition de l'idée d'impasse, ici comprise comme une situation de solution difficile ou apparemment impossible. Associés à la narrative, à lecture, comme processus, et à l'écriture, les impasses successives établissent un contact avec la notion de labyrinthe, ce qui met en mouvement ruptures et permanences d'un courant littéraire fructueux, décrit par Hugh Kenner en The stoic comedians. En permettant la coexistence de points de vue divergents et, plus que cela, à la difficulté de leur réconciliation, il est suggérée la désarticulation de la logique causale et l'avènement d'un récit qui n'est plus fondé sur les événements, mais sur le traitement du matériel linguistique. Réflexions théoriques sont faites sur le fonctionnement et les effets du texte étudié, prenant en compte les questions récentes sur les paradoxes de la fiction et les limites de la narration, basés sur une approche multiple. La bêtise, l'aspect encyclopédique du texte, la copie et le comique sont les points de départ, avec la mobilisation des connaissances comme point focal. Finalement, sont établis des parallèles entre les procédures flaubertiennes et quelques procédures adoptées depuis la fin du XIXe siècle et tout au long du XXe siècle par des artistes de formes d'expression distinctes, pour entamer des dialogues possibles.

MOTS-CLÉS: GUSTAVE FLAUBERT, ROMAN FRANÇAIS, LABYRINTHE, IMPASSE, MODERNITÉ. 


\section{ABREVIATURAS E FONTES}

As referências encontram-se no corpo do texto, no sistema autor-data, com os detalhes completos da publicação na bibliografia. Quando aspectos específicos são abordados, o leitor encontrará referências secundárias em notas de rodapé. Ao longo do texto, as abreviaturas abaixo são empregadas para referir-se aos textos de Flaubert e às traduções empregadas. As referências de outras traduções são apresentadas em notas de rodapé:

BP - Bouvard et Pécuchet. Paris: GF Flammarion, 1999 (1881). Bouvard e Pécuchet. São Paulo: Estação Liberdade, 2007 (trad. Marina Apenzeller).

CS - "Un cœur Simple", in Trois Contes. Paris: Livre de Poche, 1983 (1877).

DIR - Le Dictionnaire des idées reçues. Paris: Livre de Poche, 1997.

ES - L'Éducation Sentimentale. Paris: Pocket, 1998 (1869).

HER - "Hérodias", in Trois Contes. Paris: Livre de Poche, 1983 (1877).

LSJH - "La Légende de Saint Julien l'Hospitalier", in Trois Contes. Paris: Livre de Poche, 1983 (1877).

MB - Madame Bovary. Paris: Gallimard/Folio Classique, 1994 (1857).

SAL - Salammbô. Paris: GF Flammarion, 1992 (1862).

TC - Trois Contes. Paris: Le Livre de Poche, 1983 (1877).

TSA - La Tentation de Saint Antoine. Paris: Gallimard/Folio Classique, 2006 (1874).

A correspondência é citada pelo destinatário e pela data. 


\section{CARTOGRAFIA DE UMA ODISSÉIA}

Pode-se dizer, entre muitas outras coisas, que Bouvard e Pécuchet, de Gustave Flaubert, publicado postumamente em 1881, é um livro sobre "saber", verbo transitivo e intransitivo e substantivo, coloquem-se ou não questões sobre sua relação com um (im)possível sujeito. Seu tom profundamente irônico, com as ambiguidades inerentes à natureza do projeto, estabelece a dúvida em torno daquilo que se sabe - ou daquilo que acreditamos saber - e da própria capacidade de raciocinar, ou seja, de empregar a razão ("vouloir conclure", como afirma Flaubert em sua correspondência). A impossibilidade de decidir é apresentada ao leitor sob diversos aspectos, evidenciando a reiteração da ideia do impasse, entendido aqui como uma situação que atinge pontos de solução difícil ou aparentemente impossível. Citando aqui Beckett, mesma citação de l'Innomable que Foucault emprega no início da Ordem do Discurso:

É preciso continuar, eu não posso continuar, é preciso continuar, é preciso pronunciar palavras enquanto as há $(. . .)^{1}$

Mais além do trecho citado por Foucault, temos (em Beckett), a reiteração da necessidade da palavra para que se prossiga:

No silêncio, não se sabe, é preciso continuar, não posso continuar, vou continuar².

O impasse a que me refiro, e que pode ser associado tanto à narrativa quanto à leitura, enquanto ato, e à escrita, enquanto processo, parece-me caracterizado nas citações acima. Aparentemente circular, pois parece sugerir um retorno constante à situação inicial, a impossibilidade do avanço conjuga-se à necessidade de persistir nesse avanço; no entanto, fracassos sucessivos não são necessariamente os mesmos. "Falhar, falhar novamente, falhar melhor", escreveria o mesmo Beckett, sugerindo um impasse caracterizado pela repetição e pela diferença.

\footnotetext{
1 "Il faut continuer, je ne peux pas continuer, il faut continuer, je vais donc continuer, il faut dire des mots, tant qu'il y en a (...)." (Beckett, 1949, p. 213, tradução nossa)

2 "(...) dans le silence on ne sait pas, il faut continuer, je ne peux pas continuer, je vais continuer". (idem, ibidem)
} 
O objetivo deste estudo consiste em examinar os dispositivos e configurações do impasse em Bouvard e Pécuchet, de Gustave Flaubert, sugerindo sua aproximação à ideia do labirinto, colocando em movimento permanências e rupturas de uma vertente fecunda da tradição literária, descrita por Hugh Kenner, que abre espaço para a argumentação, para a presença de opiniões contraditórias e, mais que isso, para a dificuldade de sua reconciliação. Parece surgir aí uma narrativa que, por um lado, não é mais fundada em eventos, mas no tratamento do material linguístico e, por outro, situa o leitor como elemento intrínseco da geração de sentidos do texto.

A análise, que pretende empregar uma abordagem múltipla, parte da ideia de percurso narrativo levando a pontos "cegos" - o impasse -, que se repete em diferentes níveis de expressão. Não se busca aqui proceder ao "fechamento" do texto, atribuir-lhe um sentido delimitado e único, mas explorar a forma pela qual este texto em particular produz significância, abrindo-se para leituras múltiplas.

Ao estudar as instâncias do impasse, compreendido inicialmente como os momentos em que a narrativa parece chegar a um ponto de ruptura, que impede seu avanço, os incontáveis fracassos e a sensação de impotência que se espalham ao longo de Bouvard e Pécuchet sugerem uma quebra da lógica causal. Nosso interesse aqui é tentar entender a forma pela qual a sequência "fragmentada" de trechos pode ser apreendida como texto, em termos narrativos e epistemológicos e qual a relação desse projeto com a posição do leitor.

Como dito acima, o impasse aparece também no processo de criação, encontrando sua expressão na correspondência de Flaubert e na análise da gênese do incipit do romance póstumo.

Um dos primeiros problemas que se colocam refere-se exatamente à dificuldade em se lidar com quadros teóricos em relação a um texto cujo cerne é a impossibilidade do conhecimento por meio da razão, dificuldade, relacionada à especificidade ou "diferença" do texto em questão, desafio que Flaubert impõe ao leitor:

II faudrait que, dans tout le cours du livre, il n'y eût pas un seul mot de mon cru, et qu'une fois qu'on l'aurait lu on n'osât plus parler, de peur de dire naturellement une des phrases qui s'y trouvent. (Para Louise Colet, 16 dezembro 1852). 
Esse desafio lembra aquele exposto por Roland Barthes em uma entrevista. Ao ser questionado sobre o fato de não ter escrito obra de fôlego a respeito de Flaubert, afirma que o Urso de Croiset seria um desafio para o qual não se sentia preparado ${ }^{3}$.

O ponto de partida, exatamente por isso, são os questionamentos teóricos; o meio sugerido para que se tente ir além é a insegurança, o embate entre textos e posições divergentes.

Ao longo da pesquisa, adotamos um enfoque múltiplo, heterodoxo, na análise propriamente dita, que visa evidenciar uma poética da percepção da narrativa como momento de leitura possível, em que o texto como um todo parece exercer, a nosso ver, um efeito de epifania, no sentido joyceano ${ }^{4}$; chega-se a um estado de "percepção latente", em que os elementos de ruptura e permanência (aquilo que se mantém da tradição, do ponto de vista do sistema literário, e aquilo em que se inova) fazem com que o leitor tenha que se confrontar consigo mesmo, como se se deparasse com espelhos que o refletissem. Neste ponto, as questões de contexto, sejam chamadas formações discursivas, sejam espaço de possíveis, ganham relevância e podem ser exploradas.

$\mathrm{Na}$ análise, procuramos confrontar, sempre de forma polêmica, alguns textos, como a questão de uma estrutura "circular" ou "em espiral" em BP e as questões de representação. As listas, o hipertexto, a biblioteca e a enciclopédia são, no âmbito da pesquisa, passos intermediários na elaboração da análise, que permitirão consolidar as ideias do impasse e do labirinto, que com eles dialoga.

Finalmente, pretendemos levantar algumas outras discussões, como a hipótese de coerência de um suposto projeto e a integração da desarticulação nesse projeto, traçando, na medida do possível, alguns poucos paralelos com procedimentos adotados desde o final do século 19 e ao longo do século 20 por artistas de várias formas de expressão, como a música minimalista, a colagem, o happening etc. Logicamente, tais questões são marginais ao eixo principal do trabalho e surgem como possibilidades de desdobramentos posteriores. Apresentaremos no corpo do trabalho uma série de imagens e composições

\footnotetext{
${ }^{3}$ Embora possa ser argumentado que o Grau Zero seja, em grande parte, uma reflexão desencadeada pela escrita de Flaubert, ou pelo menos relacionada com ela.

${ }^{4} \mathrm{~A}$ epifania joyceana, termo secular, diz respeito a momentos inesperados, que produzem forte impressão, cujo significado parece desdobrar-se e expandir-se. Sobre esse emprego do termo, v. Bowen, Z. (1981-2) 'Joyce and the epiphany concept: a new approach,' Journal of Modern Literature, 9.
} 
musicais que dialogam com passagens de nossa argumentação; entretanto, visando não se afastar demasiado do objeto, não serão elaboradas considerações mais aprofundadas sobre esse material. Sua presença é justificada pela interferência que causam nas observações feitas e vice-versa.

As principais questões que se colocam referem-se à relação com o projeto flaubertiano de uma enciclopédia da bêtise humana: por que os contemporâneos de Flaubert teriam passado ao largo de suas inovações, como afirma Ezra Pound, haja vista que Bouvard e Pécuchet não teve o mesmo sucesso de, por exemplo, Madame Bovary e, levando-se em conta as próprias observações de Taine e Turgêniev a respeito de $\mathrm{BP}$, que, na correspondência, mostravam-se céticos sobre o projeto, que resultaria, no máximo, em um conto?

Além disso, por que escritores distantes no tempo e no espaço "absorvem" ou "interagem" com as realizações de Flaubert? De que forma essa apropriação reflete as necessidades de contextos tão diversos?

Surge daí a necessidade de se recolher expressões dessa centralidade de Flaubert no desenvolvimento do romance não apenas em sua tradição natal. Leituras oriundas de outras tradições, ao extrair o fato literário de seu sistema inicial e inserindo-o num sistema mais amplo, poderiam dialogar com nossas leituras, num sistema literário mundial, que reverbera ideias e realizações, fazendo com que os "mil fogos de artifício" tornem-se, em sua especificidade, ainda mais coloridos, abrindo-se a um diálogo criativo e a novas reflexões.

Cabe notar, além disso, que a realização da pesquisa foi bastante fértil em termos de questões teóricas que vão bem além dos Estudos Literários, abrangendo entre outros saberes, a Filosofia e a História. Embora nos consideremos ainda menos preparados para essa Odisseia que Roland Barthes, só nos resta seguir na empreitada. 


\section{PONTO E LINHA, DESCONTINUIDADE E CONTÍNUO}

(...) comme on contemple un voyageur qui a passé par des pays extraordinaires ${ }^{5}$

Não tentaremos iniciar por um possível começo: nosso ponto de partida será o impasse. Toda e qualquer forma de situar nosso objeto seria apenas a negação de sua própria existência.

Inacabado, póstumo, descontínuo, heterogêneo. Espécie de Fausto em duas pessoas, "um Fausto da negação proclamando a estupidez eterna de tudo, do mundo, de si-mesmo, de tudo que é inteligível em torno dele"6, a respeito do qual muito se fala, mas relativamente pouco se escreve ${ }^{7}$, constitui, a um só tempo, desafio longevo ao próprio conceito do que se entende por literatura e provocação ao crítico que intenta afrontá-lo.

Sugere a abertura para a possibilidade do fracasso, ou seja, para a busca de caminhos que eventualmente se mostrem infrutíferos, naquela que pode ser a forma possível para que se dê conta desse "não-objeto". Persegui-lo, observá-lo sobre diferentes ângulos, até que seja necessário calar-se, para então prosseguir.

Já voltando sobre nossos passos, somos obrigados a conceder. Apesar da negatividade dos parágrafos anteriores, temos, efetivamente, um objeto, um texto publicado, atribuído a Gustave Flaubert e que, com o auxílio dos pesquisadores de manuscritos - e ao seu olhar - constitui elemento passível de ser estudado, graças, dessa vez, a um novo olhar, de grau " $n$ ", do crítico, olhar mediado, que lida com pontos e linhas dispersos num plano, buscando seja a estruturação móvel desse texto, seja abraçar esse objeto recorrendo-se às condições de existência de um projeto que se afirma como "enciclopédico".

\footnotetext{
${ }^{5}$ Como Emma Bovary, Bouvard e Pécuchet abordam cada novo início como uma nova e extraordinária paisagem.

${ }^{6}$ Céard, Henry. "Portraits littéraires: Gustave Flaubert". In L'Express, 9/04/1881, apud Balansard et al., 1999. Trad. nossa

${ }^{7}$ Além de artigos, capítulos de livros e obras coletivas, poucos autores dedicaram-se a estudos de fôlego sobre Bouvard e Pécuchet. Cabe citar Descharmes, René. Autour de Bouvard et Pécuchet, Paris: Librairie de France, 1921 e Spica, Ingrid. Le statut romanesque de Bouvard et Pécuchet de Flaubert. Bruxelas: Spica édition, 1982, Leclerc, Yvan. La spirale et le monument. Paris : Sedes, 1988 e Kempf, Roger. Bouvard, Flaubert et Pécuchet. Paris: Grasset, 1990, como exceções a essa regra, todas obras relativamente difíceis de serem encontradas no Brasil.
} 
Mais ainda: tentar entender como a descontinuidade e o contínuo desse texto específico são convocados por escritores e artistas dispersos pelo mundo e separados por nacionalidades, línguas e tempos diversos para dar conta de urgências específicas. Seria possível falar em uma "tradição", mesmo tendo em vista a caracterização da descontinuidade como inerente à História, pois a noção de tradição não pressupõe, a nosso ver, apenas continuidade, e sim um complexo das infinitas combinações entre continuidades e descontinuidades.

Captar, em pensamentos heterogêneos, um possível pensamento "moderno", definido "à peu près" na linha de Marshall Berman (v. seção 2.4.2), equivaleria a ver, no ponto, na linha, no plano, "do ponto de vista de seu efeito interior sobre a subjetividade viva do espectador que os observa e os deixa agir sobre sua sensibilidade" 8 , não um significado fechado, restrito, mas possibilidades de leitura que se relacionam com diferentes discursos e condições de enunciação.

Tentar abordar Bouvard e Pécuchet, projeto inacabado de escrita também inacabada, mostra-se temeroso desde seu início. Além de se tratar de texto de escritor consagrado, no qual um mar de críticos já navegou, fazê-lo do outro lado do oceano, sem que se tenha sido embebido desde sempre nos meandros da chamada civilização francesa - o que tampouco garantiria melhor sorte na tarefa-, é o que os anglófonos chamam de catch-22 situation, ou, apoiando-se no inevitável lugar comum, "se correr, o bicho pega, se ficar, o bicho come"9; impossível escapar-se às críticas, seja quanto à abordagem, seja quanto ao eventual desconhecimento desta ou daquela tese ou artigo que trata exatamente da questão "primordial", inocentemente abordada como a descoberta de uma pedra filosofal crítica, de forma muito mais brilhante e perspicaz. Assim mesmo, é necessário enfrentar o perigo, a odisseia mais ingrata, buscando uma Ítaca indefinida.

Além desses primeiros aspectos, dedicar-se a texto e obra, aqui entendida como o conjunto de textos atribuídos a Gustave Flaubert, já amplamente estudados e dissecados, e de fazê-lo da distância que representam língua e tradição - o que leva a determinado enfoque crítico, ou seja, a priorizar o texto enquanto entidade autônoma, de certa forma destacada da situação histórica e literária -, há de se levar em conta também o fato de se tratar de texto publicado postumamente, sem que o

\footnotetext{
${ }^{8}$ Kandinsky, Wassily. Du spirituel dans l'art, Paris: éd. Denoël, 1989, p. 45.

${ }^{9}$ Duas definições interessantes de impasse.
} 
autor, considerado, por enquanto, "vivo"10, pudesse apor-lhe a marca de sua unidade, o fecho do círculo, o que tampouco garantiria reduzir-lhe as complexidades.

É claro, o paratexto que os editores disponibilizam na maioria das edições, os planos e brouillons editados nos dão a impressão de conclusão que assegura a nós, leitores, estarmos diante daquilo que chamaríamos "obra". Traçando-se um paralelo, pode-se pensar numa escultura ou concerto inacabados: teríamos um objeto, no sentido de artefato, com o qual nos relacionaríamos esteticamente. Pelo menos dois caminhos são possíveis. Para facilitar, e a despeito da diferença de material, podemos partir da escultura inacabada de Michelangelo, "Atlas", que se encontra na Galleria dell'Academia, de Florença.

Ao observarmos este trabalho, notamos, em potência, a maestria de Michelangelo no trato com o mármore. Nele temos um objeto estético, de pleno direito. Um esboço, eventuais cartas trocadas entre Michelangelo e um mecenas talvez nos dessem uma intuição daquilo que seria o resultado final, a escultura pronta. No entanto, não seria possível afirmar com segurança qual seria esse resultado final. Todo material de pesquisa, a análise de outras obras de Michelangelo, de seu processo de criação e de seu pensamento seriam extremamente úteis, ao desencadear possibilidades críticas e um possível vislumbre de nosso vigoroso Atlas.

Por outro lado, poderíamos buscar essa potência no próprio material que temos à disposição, no próprio composto de mármore e trabalho humano, extraindo da rocha um conteúdo estético possível.

De volta a nossa "enciclopédia crítica em farsa", como Flaubert descreve Bouvard e Pécuchet em sua correspondência, temos mais um problema: o próprio texto publicado, em suas diferentes edições, foi estabelecido tomando como base manuscritos também "inacabados", ou seja, o texto que temos em mãos é uma construção, sujeita a escolhas e intervenções que não são do "autor". Embora tal fato possa nos levar a questionar a legitimidade de uma análise do texto baseada num objeto "híbrido", optamos por esse segundo enfoque: considerar o texto publicado como base de nossa análise. Eventualmente, recorreremos ao material

\footnotetext{
${ }^{10}$ Se nos for permitida a pequena ironia em relação às discussões sobre a "morte" do autor.
} 
que a crítica genética coloca à nossa disposição, mas nosso ponto de partida aqui será o texto publicado ${ }^{11}$.

No contato com a produção flaubertiana, a percepção de um pensamento dito moderno emerge do relacionamento, instintivo, com a arte moderna e contemporânea $^{12}$, com que o leitor pode se defrontar ao ler textos de Gustave Flaubert. Na rubrica que abre a Tentação de Santo Antão, por exemplo, encontra-se um desafio à encenação que, a um só tempo, instaura um tempo mítico e uma provocação dignos de montagens recentes de clássicos gregos: “(...) et dans l'espace flotte une poudre d'or tellement menue qu'elle se confond avec la vibration de la lumière." (TSA, p. 51-52). O estranhamento que essa rubrica agencia parece relacionado ao jogo de expectativa projetado pelas convenções do texto dramático e à aparente impossibilidade poética da realização cênica, com seus espaços descritos com precisão peculiar, suas multidões, fantasmagorias e longos monólogos e solilóquios. O desafio de um hipotético encenador desse texto ${ }^{13}$ seria exatamente ir além de sua impossibilidade, sem descartar seu tom poético e densidade.

$\mathrm{Na}$ "Legenda de São Julião Hospitaleiro", a acurada riqueza de conteúdo poético das descrições alia-se à indeterminação do espaço descrito, relacionada à subjetividade da personagem, num jogo entre o real e o onírico que apaga certezas:

II était en chasse dans un pays quelconque, depuis un temps indéterminé, par le fait seul de sa propre existence, tout s'accomplissant avec la facilité que l'on éprouve dans les rêves. (LSJH, p. 68).

A indeterminação reiterada pode aqui ser lida tanto como o estabelecimento de um tempo e de um espaço míticos, característicos do gênero legenda, como marca de artificialidade, no sentido de objeto construído - fruto do trabalho intenso da escrita intransitiva flaubertiana.

\footnotetext{
${ }^{11}$ Levando-se em conta, inclusive, que o texto publicado foi estabelecido graças ao esforço da pesquisa genética.

${ }^{12}$ Aqui nos referimos a diversas manifestações artísticas do final do século 19 e início do século 20 e à produção posterior, que serão exemplificadas ao longo do texto.

${ }_{13}$ Em 1995, a companhia norte-americana "The Wooster Group" apresentou, no Teatro Sesc Anchieta, o espetáculo "Frank Dell's The Temptation of St. Antony", uma "reinvenção" (como consta do programa do espetáculo) d'A Tentação de Santo Antão, com Willem Dafoe. Talvez seja essa a "chave" para a encenação do texto em questão, reinventá-lo. O monólogo "A Metafísica do Amor", encenado em 2008 no teatro Ágora, alardeava em seu material de divulgação uma dramaturgia "baseada no texto de 'A tentação de Santo Antão'. A personagem principal, interpretada por Paulo Marcello, "é uma figura da contemporaneidade, que não se ajusta a determinados padrões, assim como o discurso da peça, que não tem uma lógica formal, mas sim uma justaposição de textos". (grifo nosso).
} 
Mais adiante, no final da Legenda, encontra-se um efeito de distanciamento quase brechtiano, ironicamente desestabilizando não as expectativas, mas as premissas do texto já lido, ao negar a verossimilhança genérica contida no título do conto: "Et voilà l'histoire de Saint Julien l'Hospitalier, telle à peu près qu'on la trouve sur un vitrail d'église dans mon pays." (LSJH, p. 97, grifo nosso).

Já "Um coração simples" evoca de certa forma, talvez devido à leitura de Blikstein ${ }^{14}$ e à associação (irônica) à visão do Espírito Santo, "La grande famille" (1963), de René Magritte (1898-1967), mistura de alucinação e expressão surreal, em que a silhueta de um pombo é recortada contra o céu carregado:

\begin{abstract}
Une vapeur d'azur monta dans la chambre de Félicité. Elle avança les narines, en la humant avec une sensualité mystique; puis ferma les paupières. Ses lèvres souriaient. Les mouvements de son cœur se ralentirent un à un, plus vagues chaque fois, plus doux, comme une fontaine s'épuise, comme un écho disparait; et, quand elle exhala son dernier souffle, elle crut voir, dans les cieux entrouverts, un perroquet gigantesque, planant au-dessus de sa tête. (UCS, p. 54, grifo nosso)
\end{abstract}

Nos exemplos citados, a aproximação com o teatro e a pintura foi ressaltada; pintura que move Flaubert em alguns momentos, como a "Tentação de Santo Antão", inspirada pelo quadro do mesmo nome do Brueghel Ancião ${ }^{15}$, e teatro que ocupa o solitário de Croisset entre o início da elaboração de BP e sua retomada.

Já a célebre cena das "comices agricoles", de Madame Bovary, obra que conta com pelo menos dezoito adaptações cinematográficas ${ }^{16}$, graças à simultaneidade de acontecimentos em planos distintos, dá à passagem um aspecto proto-cinematográfico, presente em outros textos escritos por Flaubert, como alguns citados acima, com passagens que dão a impressão de terem sido decupadas para sua efetiva realização enquanto cinema.

Em todas essas leituras, mais que uma racionalização ou análise, surgia a sensação de um caráter inexprimível, que, de forma semelhante, também aparecia em leituras de textos de outros escritores de períodos mais recentes e no confronto,

\footnotetext{
${ }^{14}$ Falando sobre o filme Kaspar Hauser, de Werner Herzog, cujo personagem principal passara boa parte da vida confinado, sem manter qualquer tipo de relacionamento verbal com outras pessoas, Blikstein afirma: "Qual o pássaro de Magritte, em La grande famille, uma galinha aparece-Ihe descomunal e pavorosa". Blikstein, Izidoro. Kaspar Hauser ou a fabricação da realidade. São Paulo: Cultrix, 2003, p. 15. É interessante notar que o título alemão do filme, traduzido literalmente, era "Cada um por si e Deus contra todos". Ao se perder a capacidade de julgar, seja qual for a razão, a realidade adquire face assustadora e incontrolável.

${ }^{15} \mathrm{E}$ não do mais jovem, como afirma, incorretamente, Foucault em "La bibliothèque fantastique".

16 Donaldson-Evans, Mary, "À l'écoute des adaptations de Madame Bovary", Flaubert, Traductions/Adaptations, 2009, <http://flaubert.revues.org/index579.html>. Acessado em 30 nov 2009.
} 
enquanto espectador, com outras formas de expressão, como na escultura de Giacometti (1901-1966), por exemplo, cujo tratamento ressalta a materialidade do objeto de uma forma que parece espelhar o trabalho de escrita de Flaubert, ao introduzir uma cisão marcada entre realidade e criação artística ${ }^{17}$, como a oposição entre o horizontal e a verticalidade das esculturas do primeiro e o real excessivamente construído do segundo.

Criadores dispersos no tempo, no espaço e em sua relação com a arte e com o fazer artístico, mas que sugeriam uma voz ou intento que, embora não pudesse ser reduzido a uma ideia ou conceito comum, aproximavam Flaubert de criações posteriores. É importante ressaltar que, embora se fale aqui em arte nas suas diversas formas, neste trabalho o objeto é, especificamente, a literatura.

Inúmeros estudos falam da relação de escritores com aquilo que se poderia denominar corpus flaubertianus, ou seja, de escritores que tomam para si uma suposta herança da escrita de Flaubert ou com ela dialogam, como, por exemplo, Nathalie Sarraute (1900-1999), Raymond Queneau (1903-1976), Jean Paul Sartre (1905-1980), Alain Robbe-Grillet (1922-2008) e Georges Perec (1936-1982), para ficarmos nos contemporâneos. Essa tradição vai além das fronteiras nacionais e linguísticas, incluindo figuras como Joseph Conrad (1857-1924), James Joyce (1882-1941), Jorge Luis Borges (1899-1986), Samuel Beckett (1906-1989) e John Maxwell Coetzee (1940-). Lusófonos, como Eça de Queirós (1845-1900) e Milton Hatoum (1952-), que traduziu os Três Contos com Samuel Titan Jr., engrossam essa lista, que conta ainda com intelectuais que escreveram, no âmbito de outras disciplinas, em torno de textos de Flaubert, como Michel Foucault (1926-1984) e Pierre Bourdieu (1930-2002).

Além dos autores citados, quando Jean-Paul Sartre "(s')explique (par) Flaubert"18, na obra imensa que é L'idiot de la famille, afirma que Flaubert, "créateur du roman 'moderne', est au carrefour de tous nos problèmes littéraires d'aujourd'hui." (Sartre, 1971, p. 8). Isso embora, para o mesmo autor, BP seja "(...) énorme et monotone Bouvard et Pécuchet." (Sartre, 1971, p. 640)

\footnotetext{
${ }^{17}$ Sub-repticiamente, insinua-se aqui a questão do projeto dito realista e sua relação com o real prélacaniano, que surgirá de forma reiterada ao longo do texto e que será discutida mais adiante.

18 "Quand Sartre (s')explique (par) Flaubert", Resenha de livro: Recherches \& Travaux, numéro 71, L'Idiot de la famille de Jean-Paul Sartre, Université Stendhal-Grenoble, 2007, 187 p. <http://www.fabula.org/revue/document4451.php>, Acesso em 10 nov. 2010 8:34
} 
Pois bem. A partir daí, foi preciso buscar identificar características nessa nebulosa de significados que atraiu tanta gente, para tentar discuti-la, isso caso ela realmente existisse. Surgia, promissora, a busca desses elementos nos aspectos da ruptura e da permanência. Essa "sensação" de similaridade poderia ser gerada pelo efeito simultâneo da ruptura em relação à tradição, ruptura que, por sua vez, constituiria permanências para a tradição posterior. Em outras palavras, mesmo supondo-se a história como descontinuidade, parece ser possível afirmar que essa descontinuidade carrega em si aspectos de continuidade expressa ou implícita, que pudesse responder às necessidades de momentos e contextos diferentes.

É preciso, no entanto, formular melhor essas ideias. "Tradição", "ruptura", "permanência", embora constituíssem um avanço em relação às primeiras considerações, são termos movediços e de sentido difícil de ser delimitado.

Seria, talvez, necessário buscar as condições do estabelecimento de uma linhagem do desenvolvimento do romance enquanto gênero, como afirmado pelo crítico canadense, pesquisador do modernismo que recuperou o prestígio de Ezra Pound nos anos 70, Hugh Kenner (1923-2003) ${ }^{19}$ :

Flaubert and his major successors, Joyce and Beckett, each scorching in turn the earth where his successor would sow his crop, carried forward the novel as Knowing Machine, lifelike, logical, for a hundred years (Kenner, 2005, p. xix).

Obviamente, o Urso de Croiset apropria-se de realizações de seus predecessores. Segundo Finch, algumas delas, como, por exemplo, o uso de plurais e substantivos abstratos ${ }^{20}$, provavelmente teriam sua fonte em Racine. De Biasi oferece uma visão geral do projeto flaubertiano:

Flaubert a été l'un des premiers écrivains occidentaux à donner au verbe "écrire" un usage intransitif (au sens absolu de créer une oeuvre littéraire, être écrivain ) et à définir l'écriture littéraire comme une exigence synthétique, impliquant à la fois une éthique du métier d'écrivain (la littérature d'abord, le bonheur accessoirement), une conception organique du style (unité contenu/forme : l'énoncé est indissociable du mode d'énonciation) et une série de préceptes formant système : l'évacuation de la question du "sujet" ("il n'y en a aucun, le style étant à lui tout seul une manière absolue de voir les choses"), l'axiome de Goethe ("tout dépend de la

\footnotetext{
${ }^{19}$ Nas citações buscamos fontes que englobassem leituras que não se restringissem ao sistema literário francês, pois nos parece que o sentido "moderno" de Flaubert ultrapassa fronteiras linguísticas e culturais. Tal fato não pressupõe juízo de valor, mas busca uma possível formação de leitura brasileira, que dialoga com outros sistemas literários, inclusive o francês. Além disso, as fontes citadas constituem autoridades notórias e dialogam, por sua vez, com a tradição crítica francesa, que também está presente em nosso trabalho. Finalmente, sempre que possível buscamos comentários de criadores que, nem sempre de forma objetiva, relacionam-se com o tema estudado.

${ }^{20}$ Proust analisa o uso idiossincrático flaubertiano das categorias gramaticais e dos tempos verbais.
} 
conception,... du plan"), l'impératif d'un "idéal de la prose" ("une bonne phrase de prose doit être comme un bon vers, inchangeable"), une problématisation générale des significations et l'élaboration d'une forme non-conclusive du récit ("l'ineptie consiste à vouloir conclure"), l'exigence d'impersonnalité ("il ne faut pas s'écrire. ") et ses corollaires, la relativité généralisée des points de vue et l'immatérialité de l'écriture ("les oeuvres les plus belles sont celles où il y a le moins de matière "). Pour l'essentiel, ces caractéristiques de l'écriture flaubertienne sont restées inaperçues des contemporains qui, selon les cas, ont vu dans l'œuvre une sorte de préfiguration du naturalisme ou, au contraire, une application résolue des maximes de l'art pour l'art au genre romanesque. Ce sont les écrivains du XXe siècle (notamment Proust, Joyce, les grands romanciers latino-américains, etc.) qui ont remarqué l'originalité de ce dispositif et ses singularités : des dialogues sans guillemets, réduits souvent au strict minimum et dérivant vers le style indirect, avec une propension de cet indirect à se rendre autonome sous forme d'indirect " libre "; un nouvel empire de la description qui utilise la ressource des points de vue variants, tient souvent lieu d'analyse psychologique, multiplie les visions macroscopiques de détails et donne au monde des objets une présence étrangement indépendante; un usage inédit des pronoms (les indéfinis), des temps (l'imparfait), du style indirect (l'indirect libre, souvent à attribution incertaine), de la ponctuation (tirets, pauses de souffle), des italiques et des blancs typographiques, une élaboration musicale de la phrase (rythme oral du "gueuloir", chasse aux répétitions et aux assonances), un travail d'intégration des stéréotypies verbales et une constante dissémination des clichés, syntagmes figés et idées reçues, un jeu systématique sur l'intertexte littéraire et scientifique, l'intégration constante de représentations visuelles, etc. (BIASI, 1996).

Entretanto, a mobilização dessas técnicas atenderia a diferentes programas: "in Flaubert, they tend more to create a sense of the emotion overflowing the carrier of that emotion" (Finch, 2004, p. 146). Parece ser sugerido que o concurso e a atualização de diferentes formas de uso linguístico fazem parte de uma base possível do projeto de escrita. O texto seria, assim, constituído por um acúmulo sincrônico de elementos formais diacronicamente dispersos, que ganhariam expressividade particular. Estaríamos diante de um aspecto de tradição calcado no uso da língua.

A tradição sugerida por Kenner, no entanto, é de outro tipo; pode ser definida em termos de projetos independentes, mas que apresentam um caráter de retomada em relação a seu fundamento, o reconhecimento da delimitação do material à disposição do escritor para o processo criativo.

Numa longa coletânea de escritos que tenta estabelecer um pretenso programa, Ellmann (1965, p. vi), por sua vez, sugere a existência de uma linha hereditária, que chama de tradição moderna, de artistas e pensadores situados entre o final do século 19 e o século seguinte, os quais teriam pressentido esta linhagem, "even if it is often an underground stream". (idem). Flaubert faria parte desse rio, que concorreria para a configuração da literatura posterior, de forma subterrânea.

No domínio da crítica francesa, Roland Barthes e Michel Foucault atribuem a Flaubert papel inaugural numa tradição moderna, este ao afirmar, falando da 
Tentação de Santo Antão, que Le Livre, de Stéphane Mallarmé (1842-1898), a seguir James Joyce (1882-1941), Raymond Roussel (1877-1933), Joseph Kafka (18831924), Ezra Pound (1885-197) e Jorge Luis Borges (1899-1986) tornaram-se possíveis após o livro de Gustave Flaubert (Foucault, 1983), aquele ao atribuir a fundação de uma escrita artesanal, oposta à escrita dita clássica, ao sábio de Croisset (Barthes, 1972, p. 50-51).

Dentre os autores citados por Foucault, Ezra Pound forneceu uma primeira pista, numa afirmação seca, característica do estilo corrosivo da prosa do poeta americano:

Para começar com assuntos acima de discussão, eu diria que Joyce tomou a arte de escrever onde Flaubert a havia deixado. Em Dubliners e The Portrait, ele não fora além dos Trois Contes ou de L'Education; em Ulisses, levou adiante um processo iniciado em Bouvard et Pécuchet; levou-o a maior grau de eficiência, de densidade ("compactness", no original) (...). Ulisses possui mais forma que qualquer romance de Flaubert. (Pound, 1988, p. 131).

Borges, por sua vez, afirma que:

A la imitación de la técnica de Flaubert debemos The Old Wives' Tale y O Primo Basílio; su destino se ha repetido, con misteriosas magnificaciones y variaciones, en el Mallarmé (cuyo epigrama El propósito del mundo es un libro fija una convicción de Flaubert), en el de Moore, en el de Henry James y en el del intricado y casi infinito irlandés que tejió el Ulises. (Borges, 1974, p. 266).

Robbe-Grillet, falando da narrativa "moderna" coloca desta forma o "sucesso" na tarefa empreendida pelo escritor:

Ce qui fait la force du romancier, c'est justement qu'il invente, qu'il invente en toute liberté, sans modèle. Le récit moderne a ceci de remarquable: il affirme de propos délibéré ce caractère, à tel point même que l'invention, l'imagination, deviennent à la limite le sujet du livre. (Robbe-Grillet, 1959, p. 30).

O "material" do ficcionista passa a ser a própria invenção. Partindo-se da exposição feita acima, o tratamento do complexo de tradições e rupturas disponíveis e possíveis torna-se a base do processo criativo. A narrativa "tradicional", preocupada com o relato de um evento tornara-se impossível (Robbe-Grillet, 1959, p. 31). Pode-se confrontar a afirmação acima com as duas linhagens de romancistas estabelecida por Kenner, para quem Flaubert, Joyce e Beckett caracterizam-se por empregar a "sentença" - entendida aqui na acepção de "frase", ou seja, enquanto manifestação de um sentido completo -, como unidade, enquanto Dostoievski (1821- 
1881), Tolstoi (1828-1910) e George Eliot (1819-1880) substituem-na pelo "evento" ou "acontecimento".

Narra-se pela invenção, por meio de sentenças ou de acontecimentos?

O autor de La Jalousie parece responder, em parte, à pergunta. Não haveria uma negação absoluta do evento, mas sua desestabilização, que poderia, inclusive, chegar a sua negação:

Chez Beckett lui-même, il ne manque pas d'événements, mais qui sont sans cesse en train de se contester, de se mettre en doute, de se détruire, si bien que la même phrase peut contenir une constatation et sa négation immédiate ${ }^{21}$. (Robbe-Grillet, 1959, p. 32).

Considerando-se a possibilidade da autonegação interna entre eventos, supõe-se que a base da narrativa, compreendida como alicerce do discurso romanesco, deva estar em outro elemento.

As operações realizadas com o material à disposição surgem como o procedimento básico da construção textual para um autor de uma modernidade que, como vimos, toma a oração como elemento fundamental da estrutura.

Neste ponto, surge uma primeira indagação: se a contribuição de Flaubert baseia-se na inovação formal ${ }^{22}$, como afirmado por Pound, é possível explicar a proliferação de formas do fazer literário e da literatura exemplificada pelos escritores que se relacionam com a herança do autor de Madame Bovary? Estaria, realmente, no nível da forma ou do avanço da técnica seu "sucesso" ${ }^{23}$ E seria possível explicar outras artes tomando como base esse aspecto?

\footnotetext{
${ }^{21}$ A relação com Beckett será feita na conclusão.

${ }^{22}$ O que não supõe a possibilidade de dissociação entre forma e conteúdo.

${ }^{23}$ É necessário explicitar que não é pressuposta uma dicotomia entre forma e técnica; o objetivo neste passo é tentar esmiuçar as afirmações citadas, buscando alcançar seus pressupostos e reduzir, na medida do possível, sua ambiguidade.
} 


\subsection{TRADIÇÃO, RUPTURA, MODERNIDADE}

Mais que representar um modelo contra o qual os escritores modernos tiveram que se rebelar, a obra de Flaubert incorpora uma filosofia da literatura (no mesmo sentido que a estética é uma filosofia da arte para Hegel), que, em larga escala, serve de fundo para um diálogo profícuo empreendido por escritores, do nouveau roman à literatura russa, passando pelos escritores de língua inglesa. Neste quadro, BP "continue la pensée et l'art flaubertien, mais ne continue pas cette tradition du roman ou du conte" (Read, 1967, p. 201), criando "(...) une forme qui n'avait pas son précédent" (idem). Temos, aqui, a ideia da inovação da forma; entretanto, outros elementos surgem; em primeiro lugar, é sugerida uma continuidade de um pensamento e de uma arte flaubertiana (um "estilo"?). Read afirma, tacitamente, haver uma unidade de projeto e uma ruptura com a tradição de dois gêneros. Essas relações de ruptura, permanência e unidade sugerem caminhos para o desenrolar do estudo. O romance póstumo constituiria, portanto, momento privilegiado para a análise aprofundada.

Tomando por base essas considerações preliminares, parece válido considerar a busca da explicitação de um projeto na confluência dos elementos citados: tradição, usos da língua, ruptura, incerteza... Seria preciso entender este projeto, aquele que estabelece marco no final do século 19 e que parece - no contexto de uma possível tradição - lançar nova luz também sobre a produção posterior, talvez, inclusive para além do âmbito da literatura, para as discussões sobre a arte do momento presente ${ }^{24}$. De outra maneira, pode-se também falar naquilo que diferencia BP de projetos como o expresso pelos irmãos Goncourt no prefácio de Germinie Lacerteux, com seu desígnio "realista":

Vivant au dix-neuvième siècle, dans un temps de suffrage universel, de démocratie, de
libéralisme, nous nous sommes demandé si ce qu'on appelle "les basses classes" n'avait pas
droit au Roman; si ce monde sous un monde, le peuple, devait rester sous le coup de l'interdit
littéraire et des dédains d'auteurs qui ont fait jusqu'ici le silence sur l'âme et le cœur qu'il peut
avoir. Nous nous sommes demandé s'il y avait encore, pour l'écrivain et pour le lecteur, en ces
années d'égalité où nous sommes, des classes indignes, des malheurs trop bas, des drames
trop mal embouchés, des catastrophes d'une terreur trop peu noble. II nous est venu la curiosité
de savoir si cette forme conventionnelle d'une littérature oubliée et d'une société disparue, la

${ }^{24}$ Aqui, naturalmente, nosso foco será a literatura. Mais que isso, as considerações feitas relacionamse apenas a Bouvard e Pécuchet. 
Tragédie, était définitivement morte; si, dans un pays sans caste et sans aristocratie légale, les misères des petits et des pauvres parleraient à l'intérêt, l'émotion, à la pitié, aussi haut que les misères des grands et des riches; si, en un mot, les larmes qu'on pleure en bas pourraient faire pleurer comme celles qu'on pleure en haut.

(...)

Maintenant, que ce livre soit calomnié: peu lui importe. Aujourd'hui que le Roman s'élargit et grandit, qu'il commence à être la grande forme sérieuse, passionnée, vivante, de l'étude littéraire et de l'enquête sociale, qu'il devient, par l'analyse et par la recherche psychologique, l'Histoire morale contemporaine, aujourd'hui que le Roman s'est imposé les études et les devoirs de la science, il peut en revendiquer les libertés et les franchises. Et qu'il cherche l'Art et la Vérité; qu'il montre des misères bonnes à ne pas laisser oublier aux heureux de Paris; qu'il fasse voir aux gens du monde ce que les dames de charité ont le courage de voir, ce que les reines autrefois faisaient toucher de l'œil à leurs enfants dans les hospices: la souffrance humaine, présente et toute vive, qui apprend la charité; que le Roman ait cette religion que le siècle passé appelait de ce large et vaste nom: "Humanité";--il lui suffit de cette conscience: son droit est là. (Goncourt e Goncourt, 2008, p. 7-8).

O objetivo dos irmãos Goncourt parece bastante claro, assegurar às classes baixas, no momento em que as conquistas das revoluções burguesas parecem oferecer a perspectiva de um futuro brilhante, espaço para expressão, de forma artística, de seus infortúnios, na forma que atingiu sua plenitude, o romance, buscando, acima de qualquer coisa, arte e verdade. Em suma, ocupar na arte o espaço que as classes que hoje chamaríamos de "menos favorecidas" já ocupavam no mundo.

Numa outra seara, pode-se também buscar a relação entre o projeto expresso nas "aventuras" dos dois "cloportes" e um texto que, apesar de ter obtido razoável sucesso na época de sua publicação, caiu no esquecimento:

Monnier se promenait, un soir, la canne à la main, sur le boulevard Bourdon.

Tout à coup il avise devant lui, marchant à pas comptés sur l'asphalte, un brave bourgeois du Marais, dont le chef est couvert d'un tromblon magnifique.

— Diable ! diable ! voilà un chapeau qui me contrarie, grommelle Monnier entre ses dents. II s'approche et considère attentivement ce feutre bizarre.

- Quel chapeau! quel absurde chapeau ! Le préfet de police a le plus grand tort de ne pas proscrire de semblables coiffures. Cela donne aux étrangers mauvaise opinion des modes françaises.

Tout en se parlant ainsi à lui-même, il arrive sur les talons du bourgeois.

- Corbleu ! se dit-il, j'ai une tentation. Y céderai-je ou n'y céderai-je pas? J'y cède !

Et, d'un grand coup de canne, il enfonce le couvre-chef sur les yeux du paisible promeneur.

Celui-ci se dégage avec beaucoup de peine et se retourne abruti.

Monnier, grave, immobile, se tenait à trois pas, sa canne derrière le dos.

- Ça vient de là ! dit-il en montrant les fenêtres du grenier d'abondance.

Passant ensuite avec une démarche digne et mi visage imperturbable devant l'honnête habitant du Marais, il le salue d'un air de politesse exquise et poursuit sa route. (Mirecourt, 1857, p. 77-79)

O tom irônico do trecho e as coincidências (o mesmo bulevar Bourdon, os mesmos chapéus de BP), além do desígnio expresso de apresentar uma situação 
objetiva no prefácio dos irmãos Goncourt, não impedem que nos dois textos citados seja percebido um afastamento básico em relação ao texto do solitário de Croisset, que tentaremos explicitar na sequência.

O DIR, um dos "velhos projetos" de Flaubert, surge na correspondência bastante cedo, já em 1850. Numa carta para o amigo Louis Bouilhet, é relatado o projeto de um livro

(...) complètement fait et précédé d'une bonne préface où l'on indiquerait comme quoi l'ouvrage a été fait dans le but de rattacher le public à la tradition, à l'ordre, à la convention générale, et arrangée de telle manière que le lecteur ne sache pas si on se fout de lui, oui ou non, ce serait peut-être une œuvre étrange, et capable de réussir, car elle serait toute d'actualité. (Para Louis Bouilhet, 4/09/1850)

A semelhança entre os projetos, ou melhor, entre a concepção inicial de BP e do DIR, é notável. Em primeiro lugar, o aspecto de crítica institucional, mas uma crítica voltada contra a convenção. Em segundo lugar, temos instabilidades fundamentais, entre crítica e farsa, em BP, e entre a posição do leitor e a dúvida a ser proposta, no DIR. É entendimento corrente que o prefácio ao qual Flaubert refere-se seria a própria história dos copistas. Assim, sua função seria, pode-se dizer, situar o leitor e, além disso, obter sua adesão, que sofreria um abalo pela impossibilidade de escolha de um lado. Como uma armadilha ao leitor, que se deixaria, na concepção de Flaubert, penetrar no terreno de sua ficção, até o momento em que seria impossível saber se o riso provocado pelo cômico seria um efeito de uma situação externa ao leitor ou se, efetivamente, esse riso não poderia ser direcionado ao próprio leitor, enredado de forma insolúvel.

Ao leitor, sobraria a alternativa de colocar-se em posição exterior ao texto. Mas, ao proceder dessa maneira, ele mesmo estaria engendrando o próprio desnorteamento, pois a primeira parte (BP) seria a indicação de como a segunda parte (DIR) foi elaborada. Na sequência em que seriam colocados - e formando uma unidade - os textos visavam a instabilidade entre expectativa e realização. Impossível, assim, evitar o mesmo desnorteamento daquele leitor que nega o espelhamento entre narrativa (e personagens) e leitura (e leitor) proposto. 
Guy de Maupassant, com quem Flaubert manteve uma relação bastante próxima, apresenta uma paráfrase de BP bastante curiosa:

Deux copistes employés à Paris se rencontrent par hasard et se lient d'une étroite amitié. L'un d'eux fait un héritage, l'autre apporte ses économies; ils achètent une ferme en Normandie, rêve de toute leur existence, et quittent la capitale.

Alors, ils commencent une série d'études et d'expériences embrassant toutes les connaissances de l'humanité: et, là, se développe la donnée philosophique de l'ouvrage.

Ils se livrent d'abord au jardinage, puis à l'agriculture, à la chimie, à la médecine, à l'astronomie, à l'archéologie, à l'histoire, à la littérature, à la politique, à l'hygiène, au magnétisme, à la sorcellerie; ils arrivent à la philosophie, se perdent dans les abstractions, tombent dans la religion, s'en dégoûtent, tentent l'éducation de deux orphelins, échouent encore et, désabusés, désespérés, se remettent à copier comme autrefois. (Flaubert, 1999, p. 445, grifos nossos).

Temos, assim, uma leitura do texto, que ressalta seus termos filosóficos, calcada no desejo de saber tudo, colocado no moto-perpétuo, no reinício permanente. Cabe ressaltar, no entanto, que, apesar do caráter hiperbólico da paráfrase acima, a afirmação de que as peripécias de Bouvard e Pécuchet abarcam todos os conhecimentos da humanidade parece evocar a ânsia documental de Flaubert, que, a acreditar-se em sua correspondência e anotações, teria lido para a elaboração do texto em questão mais de mil e quinhentos volumes. Os diversos capítulos efetivamente abordam diferentes saberes - e um mesmo capítulo pode abranger mais de um saber, como pode ser verificado no plano elaborado a partir da edição Flammarion de Bouvard e Pécuchet: o primeiro capítulo é a apresentação, momento em que Bouvard e Pécuchet encontram-se em Paris, indo até a primeira noite passada na propriedade de Chavignoles. O capítulo dois passa em revista a jardinagem, a agricultura, a arboricultura e a horticultura, atividades práticas, que refletem a possibilidade do emprego prático dos saberes. Se a jardinagem serve para embelezar o entorno, agricultura e horticultura têm no resultado prático (e comercial) seu suporte.

No capítulo seguinte, temos saberes que falam de forma mais próxima sobre a descrição: a Química, com suas reações que podem ser observadas e reproduzidas, a Medicina, que se baseia na descrição (pelo paciente) ou observação de sintomas, para uma possível cura, a Higiene, que descreve a forma de prevenir doenças, chegando a três campos do saber que se caracterizam exatamente pela descrição e classificação de fenômenos naturais, a Astronomia, a Zoologia e a Geologia. Os três introduzem também a questão do tempo, que se desenvolverá nos saberes abordados no capítulo quatro, a Arqueologia e a História. Aqui, volta-se à 
atividade humana, não mais com a finalidade prática do segundo capítulo, mas como busca de uma racionalidade das ações do homem.

No quinto capítulo, passa-se à Literatura, como atividade (leitura) e como fazer, caracterizado pelas representações teatrais às quais os dois copistas dedicam-se. Nos capítulos seguintes, são sugeridos saberes, como o afirma Maupassant, mais abstratos, a Política (capítulo 6), compreendida como "arte" ou "ciência" e o Amor (capítulo 7). No capítulo 8, temos de volta as questões práticas, com a Ginástica, embora ao longo do capítulo a abstração da Metafísica seja precedida pelo Esoterismo, que poderíamos compreender como uma interpenetração de práticas e do sensível com fenômenos que não podem ser descritos, pois apenas seus efeitos o são. Seguem-se a Religião (capítulo 9) e aquela que seria o ápice da atividade classificatória e crítica, a Educação (capítulo 10), que deságua numa prática.

É evidente que saberes importantes não se encontram contemplados nessa lista, como os diversos ramos da Matemática, a Música e assim por diante. Tampouco saberes ligados às técnicas industriais, como a metalurgia, respeitáveis ao longo da segunda Revolução Industrial. No entanto, a multiplicidade de saberes citados já causa estranheza. Note-se que o tratamento dos saberes e de sua especificidade, como expresso no plano do texto publicado, indica a busca de uma variedade em seu tratamento, um deslocamento entre conhecimento (saber) e prática que é desigual, pela própria natureza dos saberes, de onde se poderia concluir que não é aventada a possibilidade de uma ação única - de um método único - no embate com o real.

Se os saberes não são homogêneos, tampouco o pode ser a ação diante deles. Cada saber organiza a realidade, seja ela compreendida em termos de atividades, como a horticultura, ou de categorias, como o tempo ou os elementos, de acordo com uma provável lógica específica, mas que não é passível de apreensão apenas pela informação fornecida pelos livros, nem pelos sentidos, nem pelo raciocínio lógico. Bouvard e Pécuchet são vítimas dessa aporia. Por isso, embora partam sempre do início, como se não aprendessem com seus insucessos, parecem enfrentar cada passo como se fosse inaugural, ou seja, respeitam a especificidade de cada ação, de cada gesto, de cada saber. Mas, e esse é o elemento trágico dessa epistemologia inerte, fracassam. 
O bom senso sugere que se aprenda com as experiências anteriores, mas esse aprendizado não garante o sucesso das experiências posteriores, assim como, no caso dos copistas, o desprezo pelo bom senso e pelas experiências anteriores, sejam elas próprias ou de terceiros, também não funciona. $O$ leitor, baseado no próprio bom-senso, aceita a comicidade de duas personagens indefinidas, que variam ao longo do texto, sem perceber que ele próprio poderia estar refletido nesse empreendimento recursivo.

Voltando à estrutura do romance, Ton-That (1999, p. 32-34) desenvolve uma análise em que compara um plano publicado na edição crítica de A. Cento e o texto publicado, demonstrando que a ordem e o conteúdo mudaram pouco entre plano mais antigo e o texto publicado postumamente, notando também uma menor coerência nos capítulos finais, que, no plano, tratariam de Religião (cap. 8), Socialismo (cap. 9), e o "décimo capítulo", que não é numerado no plano e consiste na palavra "Cópia", seguida de um ponto de exclamação. Além disso, é evidenciado que a transição entre um capítulo e outro perdem a coesão encontrada no início do texto. Finalmente, as subdivisões de cada capitulo, os "ramos" do saber, são menores nos capítulos finais, o que o autor citado entende como uma tentativa de não mais se dispersar "nos meandros de um saber fragmentário e estéril" (ThonThat, op. cit., p. 34, tradução nossa).

Cabe lembrar que a leitura do romance em questão, por seu inacabamento, ao levar em conta o plano dos capítulos 11, que incluiria um grande repertório da burrice humana, "citações constituindo um vasto bestiário", e 12, que concluiria a narrativa, baseia-se em hipóteses de leitura. Uma dessas hipóteses acaba por instaurar uma resolução arbitrária, um retorno ao início, à cópia "como antigamente", como afirma Maupassant. Ora, sabe-se que esse "como antigamente" deveu-se a uma interpolação efetuada pela sobrinha de Flaubert, Caroline, responsável pelos manuscritos após a morte do tio. Embora edições mais recentes "corrijam" essa interpolação, acreditamos que a visão de uma estrutura circular do romance constitua eco desse "retorno ao início"25.

Embora a "repetição incessante da mesma situação" constitua aspecto fundamental do texto, entendemos que essa repetição ocorre em termos de impasse e fracasso; em outras palavras, a repetição do motivo não implica necessariamente

\footnotetext{
${ }^{25}$ Esta questão será retomada mais adiante.
} 
numa estrutura "circular", pois, além da evidente estrutura dos capítulos, englobando saberes que são abordados de acordo com sua especificidade, o motivo é modificado, "desenvolvido", empregando-se um termo de teoria musical. O fracasso é antecedido por percursos que se diferenciam entre si.

Thon-That, por exemplo, embora afirme que a "estrutura do livro é arborescente, com cada capítulo correspondendo a um ramo que se divide em ramos menores" (Thon-That, 1999, p. 33, tradução nossa) ${ }^{26}$, volta sobre seus passos algumas páginas mais adiante:

La dernière exclamation du plan ancien déjà mentionné (...) et la fin du plan du chapitre $X$ mettent en relief la structure circulaire et la dimension spéculaire de l'œuvre qui renvoient à l'activité initiale des deux personnages qui étaient copistes et le redeviennent, car "ils n'ont aucun intérêt dans la vie". (Thon-That, 1999, p. 36).

Ou seja, o autor "atualiza" sua visão da estrutura da obra, passando do arborescente para a "estrutura circular" e a "dimensão especular". Esse desvio da primeira leitura sugere a necessidade de "adequação" a uma leitura "canônica" do texto.

Para um leitor já afeito ao efeito cômico de duplas, que acabam formando quase que um único personagem clivado, o emprego da caricatura pode embaralhar o dado filosófico que serve de fundo ao texto, a questão do limite do saber. Como afirma Fournier, o objetivo de Flaubert seria a crítica do racionalismo de sua época, que se baseia na busca do absoluto por meio de um relativismo cético:

Flaubert a choisi la comédie - genre critique par excellence- pour mettre en scène un mal qui a marqué sa pensée et qui caractérise toute son œuvre. Bouvard et Pécuchet incarnent, de façon caricaturale, bien sûr, le mal du rationaliste moderne, qui ne trouve que contradictions partout, désespéré de connaissance absolue, et conclut cyniquement qu'on ne peut rien affirmer. Alors, disent les nouveaux romanciers, "copions". (Fournier, 1974, p. 78, grifo nosso)

Reteremos dois pontos desta primeira parte: se, como veremos adiante, por um lado, a descrição assumiria proeminência no romance dito realista ${ }^{27}$, o tênue fio narrativo que se pode depreender da paráfrase feita por Guy de Maupassant parece sugerir um arcabouço para um procedimento que vai além do desenvolvimento narrativo. Por outro lado, a amplitude de saberes convocados, evidenciada pela

\footnotetext{
${ }^{26}$ "La structure du livre est arborescente, chaque chapitre correspondant à une branche qui se divise elle-même en branches plus petites."

${ }_{27}$ Para uma breve, mas interessantíssima, exposição sobre as diferentes funções da descrição na narrativa, v. Caliendo, 2010, p. 97-100.
} 
organização do texto e sua divisão em capítulos, surge como desafio ao leitor, motivando um maior envolvimento por ocasião da leitura - ou, caso a adesão do leitor não seja obtida, ao fracasso, ao seu abandono. Os dois aspectos sugerem um papel mais ativo do leitor, seja por meio da adesão, seja pelo abandono da leitura.

Já em outubro de 1872, a enciclopédia crítica em farsa passa a ser descrita como "encyclopédie de la Bêtise moderne" ${ }^{28}$. A crítica passa a confundir-se com a aproximação dos saberes à tolice, à ausência de inteligência, à incapacidade de compreender e agir. Se, por um lado, o material parece ser inesgotável, bastando estar alerta para obtê-lo, por outro, Flaubert expressa a dificuldade em trabalhar esse material, ou seja, transformá-lo em texto:

II faut être maudit pour avoir l'idée de pareils bouquins! J'ai enfin terminé le 1er chapitre et préparé le second, qui comprendra la chimie, la médecine, et la géologie, tout cela devant tenir en 30 pages! et avec des personnages secondaires, car il faut un semblant d'action, une espèce d'histoire continue pour que la chose n'ait pas l'air d'une dissertation philosophique. (Para Edma Roger des Genettes, 15/04/1875, grifo nosso)

Do ponto de vista narrativo, embora Flaubert busque certa forma de ruptura, caracterizada pelo abandono do evento como foco, passando a um ideal em que o trabalho com o material linguístico seja proeminente, é sugerida a necessidade de certa permanência, a sensação de um fio narrativo, que, na carta em questão, parece ser função atribuída aos personagens secundários. Ao invés de peripécias e reconhecimentos aristotélicos, Flaubert buscava o Texto, unidade de forma e conteúdo que, apesar de não depender de representação - e sequer da realidade, como forma de legitimação, não podia prescindir totalmente de marcas que permitissem reconhecer o texto enquanto tal. Reiteradas vezes, o urso de Croiset expressa suas intenções e o esgotamento que o toma ao longo do exaustivo trabalho, com os resultados previsíveis: as páginas parecem-lhe impossíveis, sua desolação, "indescritível"29. Para Émile Zola, Flaubert afirma que o livro o faz viver "dans le tremblement". O problema do projeto seria conseguir a variação ${ }^{30}$, o que dá a entender que o material seria homogêneo e que, para tornar interessante esse material, seria necessário elaborá-lo de forma a atribuir-lhe interesse. No entanto, como vimos acima, os saberes são trabalhados em sua especificidade e o que se repete é o fracasso.

\footnotetext{
${ }^{28}$ Para Adèle Perrot, 17/10/1872.

29 Para Edma Roger des Genettes, 26/09/1874.

${ }^{30}$ Para Caroline, 15/10/1874.
} 
Diferentemente de leituras que afirmam tratar-se da repetição da mesma situação, entendemos que o que unifica as experiências de Bouvard e Pécuchet é o fracasso reiterado. Tomando por base essa leitura, pode-se compreender o trabalho de Flaubert como sendo a elaboração de um texto centrado no fracasso repetido e que fugisse à monotonia. Se o fizesse, seria "le comble de l'Art"31.

Como afirmado por Flaubert, a "clef de voûte" do texto seria sua unidade:

II n'aura de signification que par son ensemble. Aucun morceau, rien de brillant, et toujours la même situation, dont il faut varier les aspects. J'ai peur que ce ne soit embêtant à crever. ${ }^{32}$

A citação acima parece confirmar a observação. A situação que se repete refere-se, nessa chave, à reiteração do fracasso, o que faria com que apenas o todo, o texto compreendido enquanto bloco provido de significância ${ }^{33}$, que leva à consideração do próprio fracasso da narrativa, como afirmado por Flaubert.

A importância do projeto para Flaubert, portanto, estaria na criação de um efeito de conjunto, causado por meio da repetição incessante da mesma situação, que deveria apresentar-se de forma variada. Como definir tal concepção? Fazendose uma analogia com a música, pode-se pensar num motivo ou célula musical e suas variações. Seria precipitado ver aqui um prenúncio de um minimalismo, representando na música por Steve Reich (1936-) e renegado por Philip Glass (1937-), e que Sol LeWitt (1928-2007) e Frank Stella (1936-) transformaram em movimento nas artes plásticas nos anos 60 do século 20, ambos fenômenos norteamericanos da era da Guerra Fria. Seria necessário explorar outras premissas de cada um dos projetos (o flaubertiano e o minimalista) para, só então, fazer qualquer afirmação ${ }^{34}$. Mas, em se tratando de Bouvard e Pécuchet, essa também seria uma tarefa impossível, pois fadada ao fracasso do desconhecimento "de tudo":

Pour la juger impartialement, il faudrait avoir lu toutes les histories, tous les mémoires, tous les journaux et toutes les pièces manuscrites, car la moindre omission une erreur peut dépendre qui en amènera d'autres à l'infini. Ils y renoncèrent. (BP, p. 174)

Retomando o aspecto que se poderia chamar de enciclopédico, numa carta de dezembro de 1879, surgem afirmações importantes:

\footnotetext{
${ }^{31}$ Idem.

32 Para Émile Zola. 5 de outubro de 1877.

${ }^{33}$ Apesar do anacronismo, considero válido empregar o termo de Barthes.

${ }^{34}$ Retomaremos esta discussão mais adiante.
} 
Ce que c'est ? Cela est difficile à dire en peu de mots. Le sous-titre serait : Du défaut de méthode dans les sciences. Bref, j'ai la prétention de faire une revue de toutes les idées modernes. Les femmes y tiennent peu de place, et l'amour aucune. Votre américain a été mal renseigné. Je crois que le public n'y comprendra pas grand-chose. Ceux qui lisent un livre pour savoir si la baronne épousera le vicomte seront dupés, mais j'écris à l'intention de quelques raffinés. Peut-être sera-ce une lourde sottise ? A moins que ce ne soit quelque chose de très fort ? Je n'en sais rien! et je suis rongé de doutes, accablé de fatigue. ${ }^{35}$

Há aqui a passagem da enciclopédia para a catalogação das "ideias modernas", ao mesmo tempo em que se antecipa o discurso sobre o fracasso do método. Indo mais além, Flaubert impõe um desvio em relação a certo ideal de literatura, aquele em que o leitor busca satisfazer sua curiosidade; mais que isso, insere a possibilidade do fracasso na própria realização da empreitada.

Temos uma sucessão de círculos não concêntricos: além da própria impossibilidade de catalogar o universo das ideias correntes, há a impossibilidade do leitor médio, que não poderá compreender o livro por vir (diferentemente do leitor de Stendhal, que terá que esperar "apenas" o próximo século). Os "happy few" partilhariam, talvez, das mesmas dúvidas de Flaubert, que vê o projeto como um impasse iminente.

Retomando a introdução dos irmãos Goncourt e a passagem anedótica, Flaubert não busca a "Arte e a verdade" dos primeiros, que veem o "Romance" como gênero sério "por excelência" e, simultaneamente, como forma de fazer ver a realidade aos felizes de Paris, nem o humor simples, quase infantil, das biografias de Mirecourt, humor voltado para um público amplo, que não se interessaria, talvez, por reflexões mais profundas.

\footnotetext{
${ }^{35}$ Para Madame Tennant, 16/12/1879.
} 


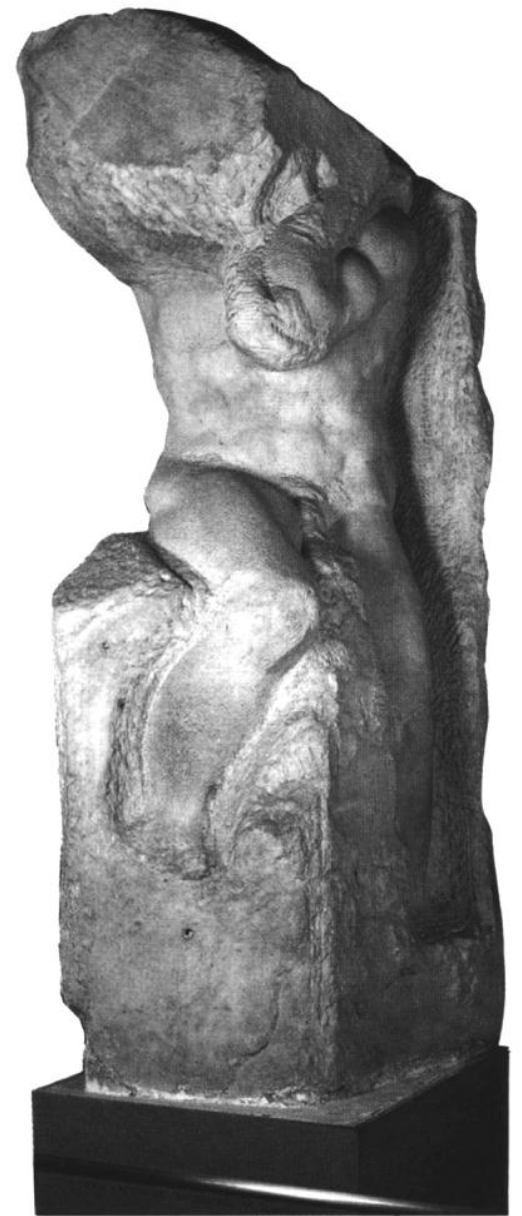

Michelangelo Buonarroti, Atlas (reprodução) 


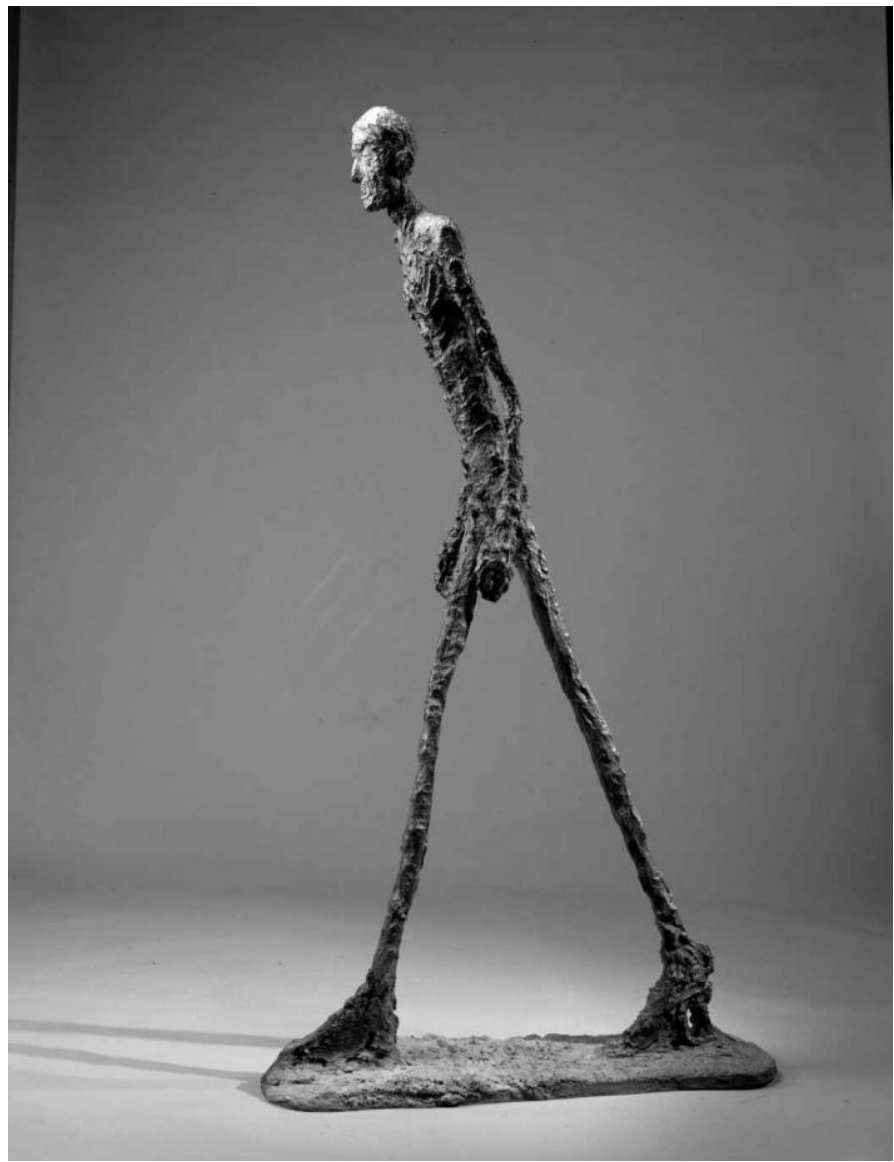

Alberto Giacometti (reprodução) 


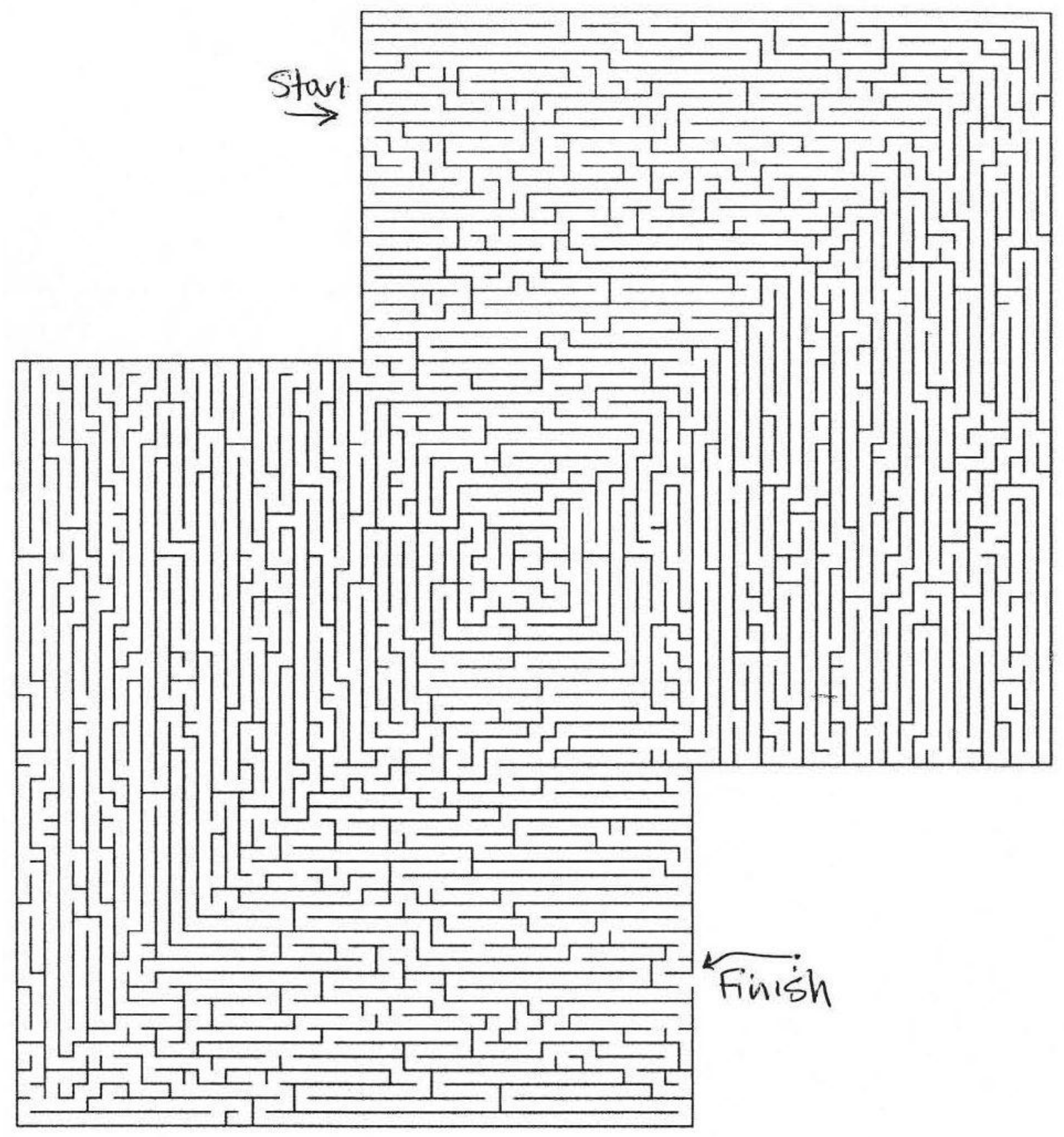

Labirinto complexo (reprodução) 


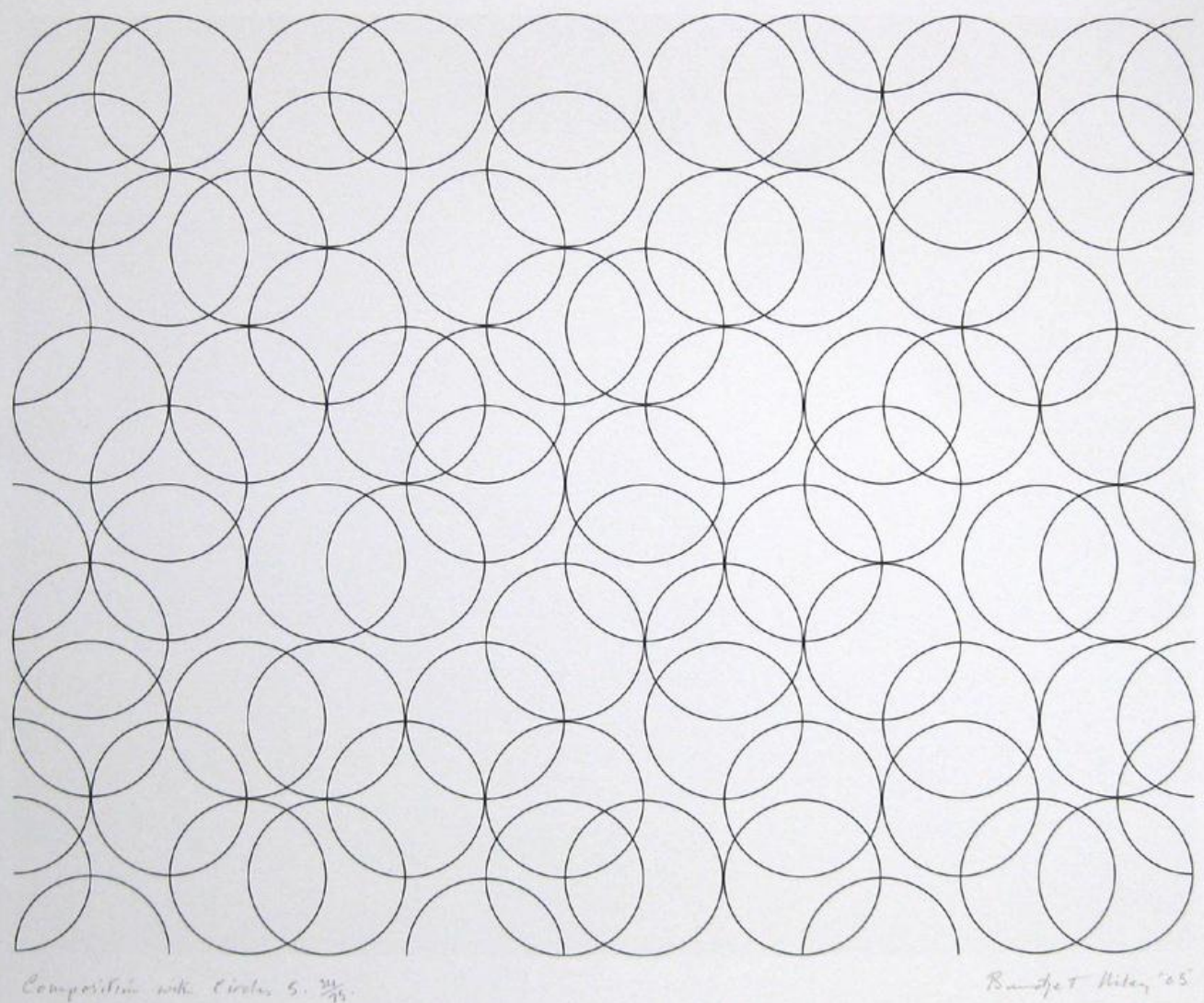

Bridget Riley. Composition with circles 5, 2005 (reprodução) 


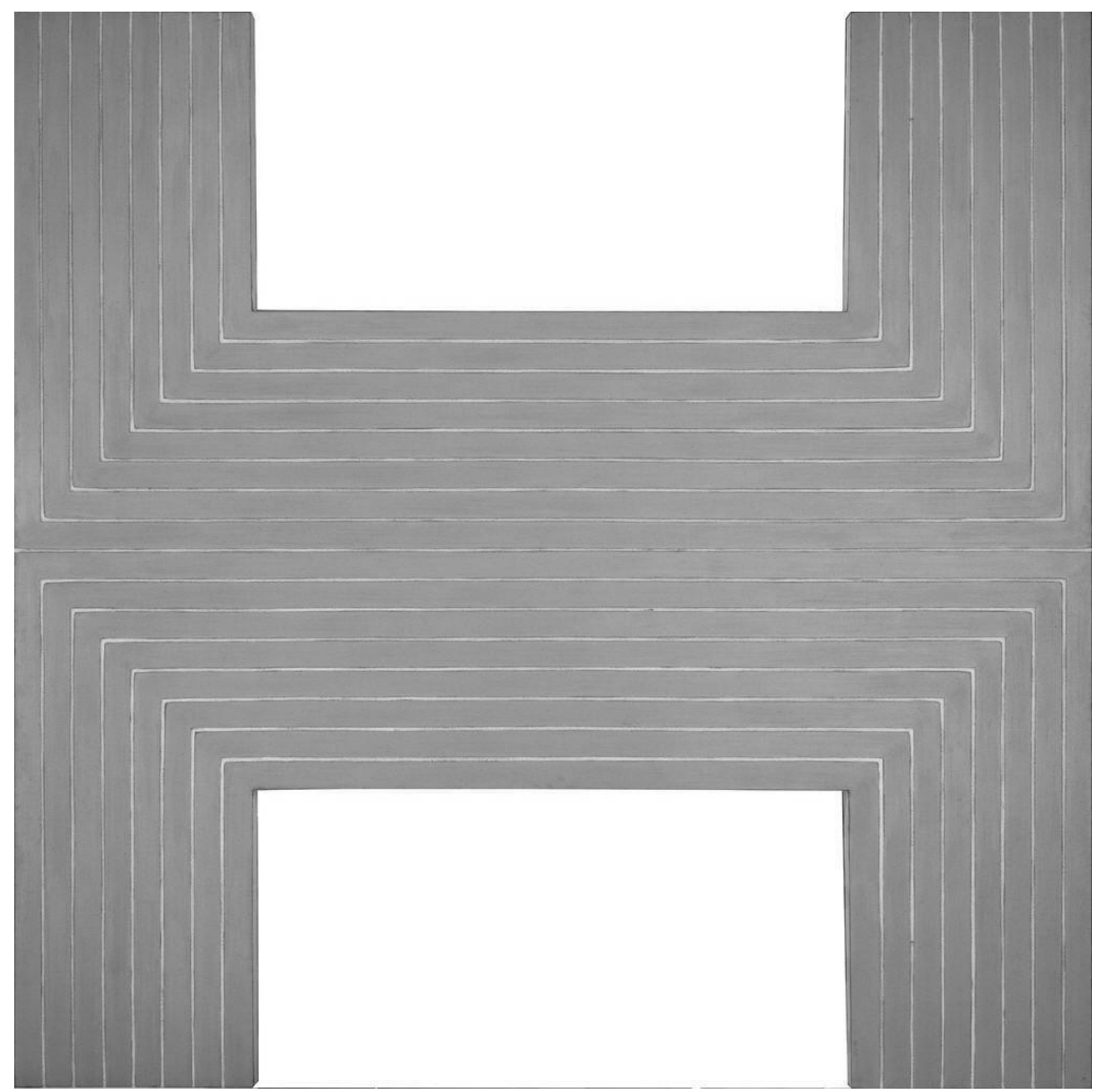

Frank Stella, Pagosa Springs, 1960, (reprodução) 


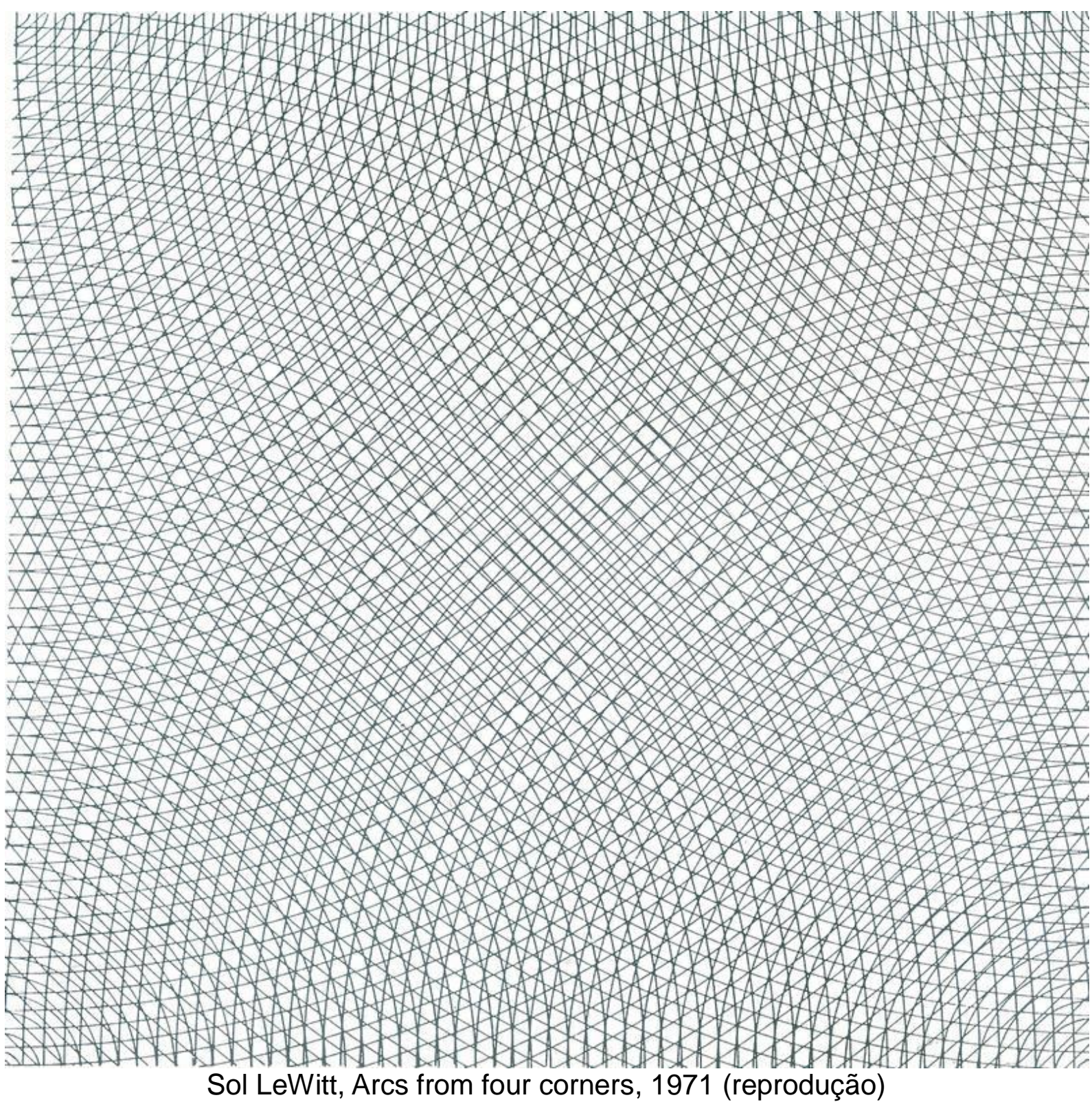




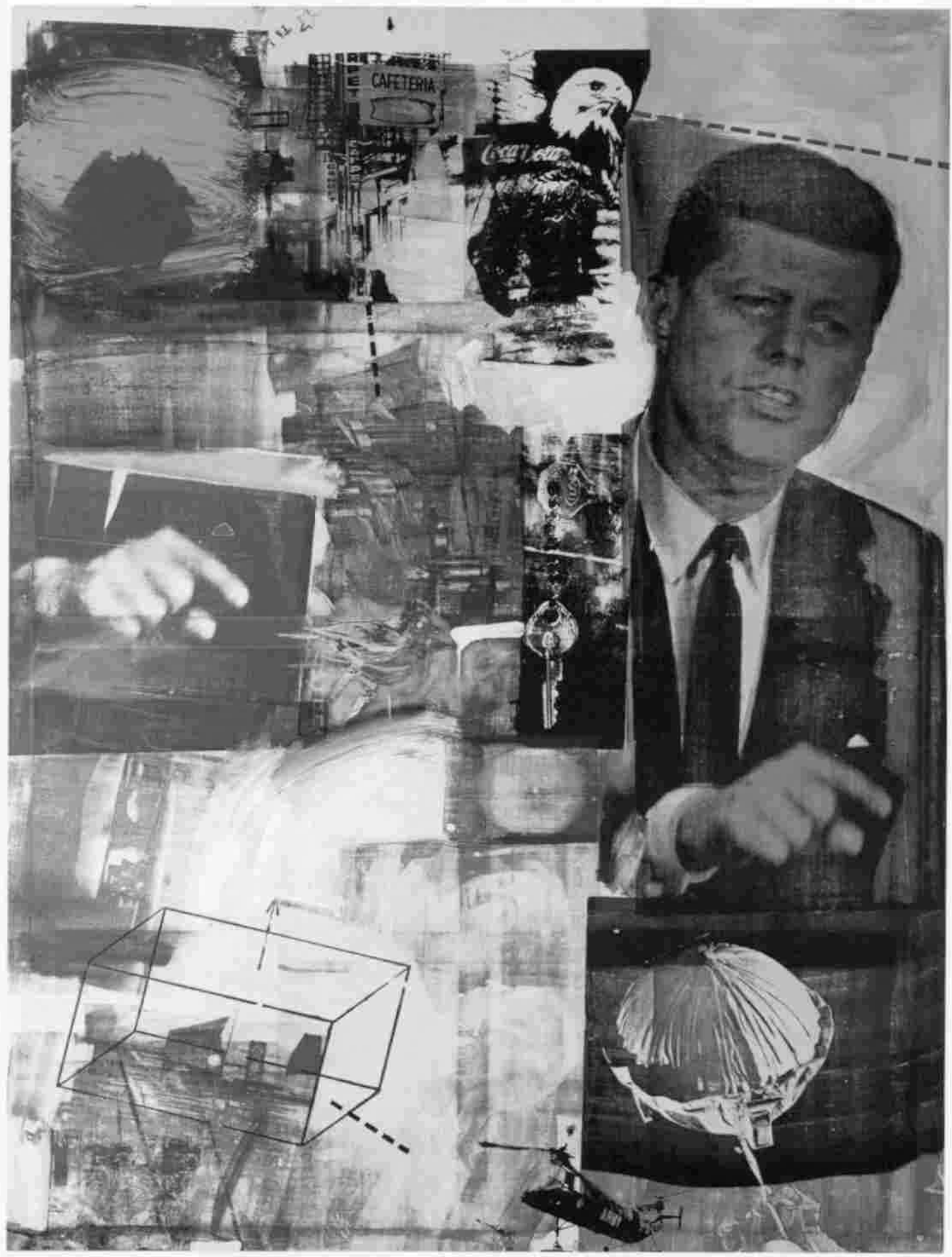

Robert Rauschenberg, colagem (reprodução) 


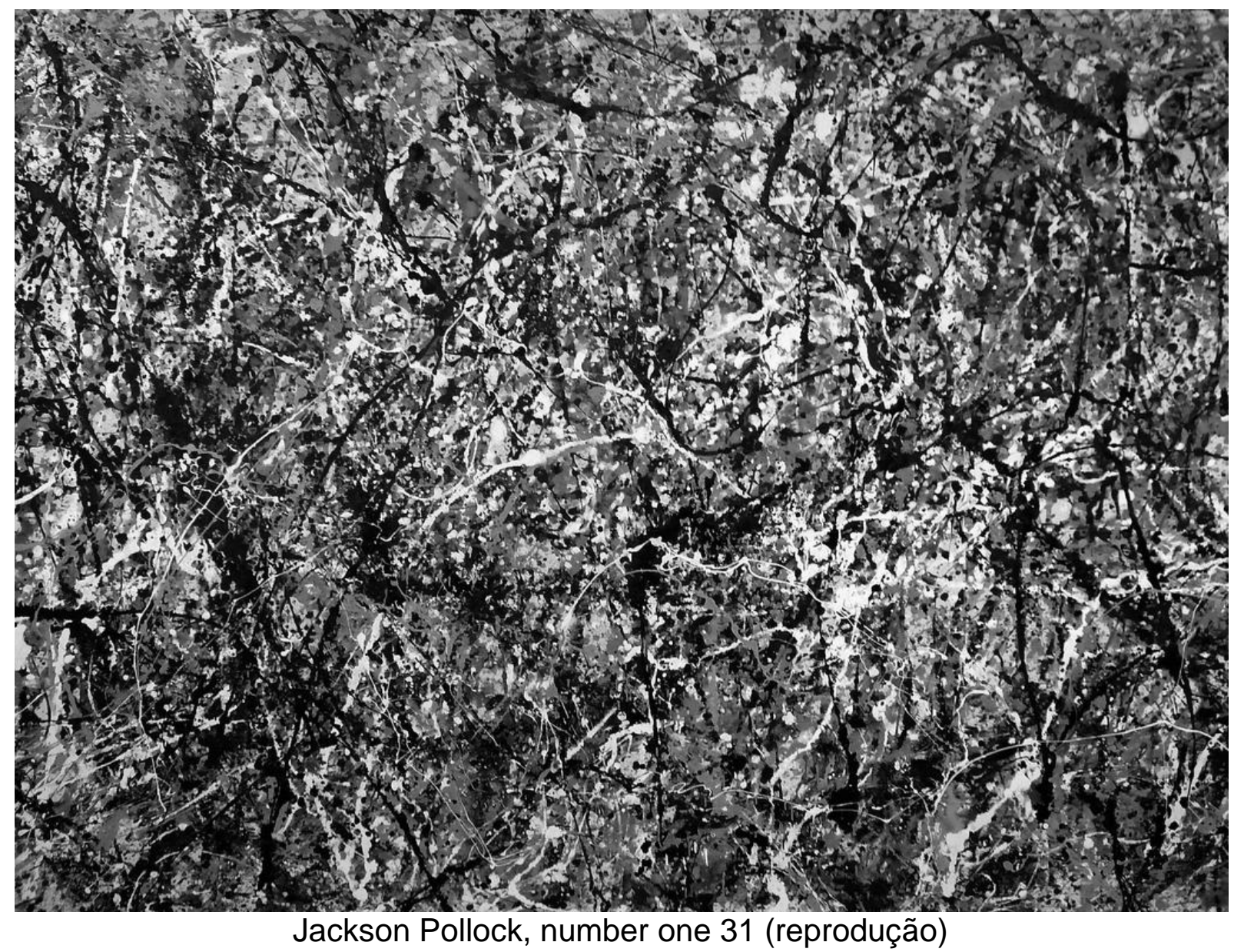




\subsection{LABIRINTO E ESPELHO}

\subsubsection{INTERSTÍCIO DAS PALAVRAS}

Retomamos a questão sobre a estrutura de Bouvard e Pécuchet, que se encontraria numa pretensa circularidade. Para Duchet, por exemplo, "l'ensemble (...) tient son existence textuelle de ce mouvement circulaire qui renvoie sans cesse des matériaux à leur élaboration fictionnelle et de celle-ci à ceux-là" (Duchet, 1980, p. 109), chegando mesmo a falar em circularidade viciosa (idem, p. 110).

Duchet fala em "materiais" e "elaboração ficcional", ou seja, sua preocupação encontra-se no nível da "escritura", da relação entre criação (elaboração) e sociedade (Barthes, 1972, p. 18) ${ }^{36}$. Coloca-se imediatamente a discussão da coesão do texto, isto é, de sua percepção como um todo - sua existência textual, como afirmado.

Fazendo-se um paralelo com as técnicas empregadas nas artes visuais no século 20, como a colagem, por exemplo, pode-se imaginar que essa existência textual é obtida, como o desejava Flaubert, por seu efeito de conjunto. Os fragmentos (materiais) são reconhecidos em sua individualidade, mas, sua impressão é obtida por meio de sua seleção e disposição. Daí, pode-se passar à discussão da experiência estética como relacionada seja à percepção da célula constitutiva individual, seja à percepção do objeto em sua totalidade, ou - e esse é o ponto central - na relação entre a parte e o todo, que, em Duchet, parece subordinar-se à elaboração ficcional do texto e não à sua percepção enquanto objeto estético, em nosso caso específico, na leitura.

A própria importância da relação entre a obra enquanto elaboração e possibilidade de interpretação não parece ser levada em conta, nos limites do trecho citado. A simples existência de um princípio unificador não garante qualquer forma de transcendência. Em outras palavras, a circularidade como metáfora estruturante pode ser aplicada também a um manual de economia política ou de gestão de

\footnotetext{
36 "Langue et style son des objets; l'écriture est une fonction: elle est le rapport entre la création et la société, elle est le langage littéraire transformé par son destination sociale [...]".
} 
recursos humanos, como fundamento de um esforço didático ou discursivo (no sentido filosófico, de operação mental).

Temos aqui caminhos possíveis para interpretação: caso possamos confirmar essa circularidade, cabe-nos analisá-la de um ponto de vista retórico/literário; entretanto, caso essa circularidade possa ser refutada, nosso objetivo seria explicitar uma alternativa a essa visão.

Stéphanie Dord-Crouslé, diretora do projeto do acervo Bouvard e Pécuchet ${ }^{37}$, por sua vez, afirma que as críticas oferecidas por Taine e Turguêniev a respeito do projeto de Flaubert não levavam em conta a poética interna ${ }^{38}$, que seria, segundo ela, definida pelo autor como seu fundamento. Em carta a Turguêniev, Taine afirma que, devido ao "esprit de système, concentration solitaire, étude prolongée aux bibliothèques", o urso de Croiset acabaria chegando "à l'histoire, à la critique bibliographique, aux restitutions érudites, et non aux romans" (carta de 21 de março de 1878). Já Turguêniev é bastante crítico a respeito do projeto de um romance, sugerindo que o material seja suficiente apenas para um conto.

A pesquisadora afirma ser difícil "fazer uma ideia precisa do aspecto que o segundo volume finalmente teria", concluindo que seria possível ao leitor "imaginar como seria, em linhas gerais, esse projeto dificilmente concebível e cujo equilíbrio repousa em uma estrutura em espiral' (BP, p. 20). Prosseguindo, Dord-Crouslé fala em "impressão de circularidade" e na presença da circularidade em outros níveis do texto (idem, p. 21). Haveria uma progressão da complexidade estrutural entre $A$ Educação e Bouvard, atribuindo-se essa modificação à passagem do círculo, na primeira, à espiral, no segundo. A retomada da cópia, assumida como "fecho" desejado do texto, não seria um simples da capo, uma repetição do mesmo percurso, e este fato parece ser um pressuposto aceito por boa parte da crítica, à exaustão. Entretanto,

(...) se os dois homenzinhos recomeçam a copiar ao termo de suas aventuras ('Acabar pela visão dos dois homenzinhos debruçados em suas escrivaninhas copiando') não é 'como outrora', embora uma interpolação lamentável de Caroline, a sobrinha de Flaubert, tenha dado essa impressão por muito tempo ${ }^{39}$. O processo de Cópia provoca na verdade a volta, mais uma vez, de todas as áreas consideradas nos capítulos anteriores, porque Bouvard e Pécuchet

\footnotetext{
${ }^{37}$ Este projeto tem como finalidade editar online os manuscritos de Bouvard e Pécuchet, mantidos na biblioteca municipal de Rouen <http://dossiers-flaubert.ish-lyon.cnrs.fr>, acessado em 19 ago 2009, 22:56.

${ }^{38}$ Apesar de nosso interesse pela poética, cabe perguntar se existiria uma poética "exterior"; mesmo as poéticas normativas partem da realização artística para sua formulação.

${ }^{39}$ Caroline teria adicionado "comme autrefois" ao texto, dando a sensação do retorno ao início.
} 
copiariam as anotações dos autores lidos anteriormente. Mas o processo não se detém aqui. $\mathrm{O}$ Dicionário das ideias feitas também faz parte da Cópia e comporta muitos tópicos que dependem das áreas anteriores da enciclopédia - mais um círculo fechando-se. Finalmente, no décimo segundo e último capítulo ${ }^{40}$, a espiral continua a girar sobre si mesma, erguendo-se ou afundando, não se sabe. Pois o rascunho da carta de Vaucorbeil ao prefeito, encontrado por Bouvard e Pécuchet, operaria um último regresso ao conjunto das experiências precedentes: "Resumindo todos os seus atos e ideias, deve constituir para o leitor a crítica do romance." (BP, p. 23)

Fixando-se o parágrafo acima, a impressão é antes de uma série de círculos concêntricos, de movimentos inaugurais e retornos a esses movimentos. Talvez nessa visão encontre-se a base da afirmação frequente de que nossa enciclopédia crítica em farsa seria não apenas inacabada, mas infinita, pois compreenderia texto, crítica ao texto e resumo dinâmico de ações e pensamentos, relacionados à Cópia eterna. Exemplificando essa corrente, temos uma afirmação da mesma autora:

A estrutura em espiral do romance faz parte de uma construção em que tudo é pensado (o tratamento dos saberes, a elaboração da psicologia dos personagens ${ }^{41}$ e o encadeamento dos episódios) para tornar impossível a conclusão. A 'enciclopédia crítica em forma de farsa' mantém-se assim a igual distância do manual (resumo do que se considera verdadeiro) e do panfleto (exposição do que se denuncia). A ficção de Flaubert não visa resolver os problemas de que trata. Efetua com eles uma montagem significativa. (BP, p. 25)

A ideia de uma volta ao percurso anteriormente seguido poderia levar a supor os mesmos impasses e fracassos. Uma espiral, no entanto, sugere uma aproximação permanente ${ }^{42}$ ao centro em torno do qual se faz essa revolução, eventualmente chegando-se a ele - e a um novo impasse: para onde ir então? Falase em volta das áreas abordadas nos capítulos anteriores, embora o Dicionário das ideias feitas seja, ao mesmo tempo, uma nova enciclopédia e contenha em si algumas das áreas abordadas; conquanto a conclusão seja impossível, o esboço da carta representaria uma volta derradeira.

No entanto, uma releitura do trecho citado do manuscrito, o esboço do capítulo 12, pode indicar outro caminho:

Un jour, ils trouvent (dans les vieux papiers de la manufacture) le brouillon d'une lettre de Vaucorbeil à $\mathrm{M}$. le Préfet.

Le préfet lui avait demandé si Bouvard et Pécuchet n'étaient pas des fous dangereux. La lettre du docteur est un rapport confidentiel expliquant que ce sont deux imbéciles inoffensifs. En résumant toutes leurs actions et pensées, elle doit pour le lecteur, être la critique du roman.

${ }^{40}$ Este é um dos capítulos deixados inacabados. Voltaremos à questão desse "inacabamento" de Bouvard e Pécuchet mais adiante.

${ }^{41} \mathrm{Cf}$. com a afirmação de Deleuze mais adiante.

${ }^{42} \mathrm{Ou}$, ao contrário,um afastamento de um possível centro. 
-"Qu'allons-nous en faire ?" - Pas de réflexion ! copions ! II faut que la page s'emplisse, que le "monument" se complète - égalité de tout, du bien et du mal, du beau et du laid, de l'insignifiant et du caractéristique. II n'y a de vrai que les phénomènes. -

Finir par la vue des deux bonhommes penchés sur leur pupitre, et copiant. (BP, 390).

Inicialmente, cabe observar que a carta de Vaucorbeil assume, presumivelmente, já que não dispomos do texto acabado, mas sim de um projeto, um caráter de comentário. A revisão em forma de crítica, e não o mero retorno, surge como um eco da observação irônica ao final da Legenda de São Julião, pois o leitor seria confrontado exatamente com o fracasso do método nas ciências.

Levando-se ao extremo a proposta da repetição da mesma situação afirmada por Flaubert, o retorno à cópia pode ser visto como uma resposta crítica de Bouvard e Pécuchet à carta de Vaucorbeil, esta representando "para o leitor" (o burguês que seria o alvo da crítica de Flaubert) a crítica ao risível comportamento dos copistas, enquanto a cópia de "tout ce qui leur tomba sous la main" (BP, p. 389), e não apenas dos tópicos pelos quais passaram anteriormente, sugere, a meu ver, um fecho na própria impossibilidade de parar - o que não quer dizer que o texto "deixe" de significar, mas que a narrativa se esgota.

O burguês razoável, representado por Vaucorbeil - e pelo leitor - ri da comicidade gerada pelo efeito da repetição, até, talvez, dar-se conta que sua própria vida é uma repetição - uma comédia de erros - constante. Não importa saber se a odisseia de Bouvard e Pécuchet será eterna: o recado está dado.

Tanto círculo como espiral parecem, a nosso ver, pouco apropriados para compreender a forma pela qual o texto desencadeia leituras, pois ambos operam, salvo engano, num "sobrevoo" do texto, sem que se passe a um embate mais próximo com estruturas menores, que poderiam, talvez, refutar essas metáforas. Cumpriria, pois, proceder a esse trabalho de aproximação e afastamento, com o objetivo de, pelo menos, levar em conta esses aspectos ${ }^{43}$.

\footnotetext{
${ }^{43}$ Essa "tentação" do projeto enquanto plano geral parece originar-se de afirmações de Flaubert em sua correspondência. Escrevendo a Louise Collet, ele afirma que:
}

Les perles ne font pas le collier, c'est le fil. De ce que j'avais beaucoup travaillé les éléments materiels du livre (refere-se à Tentation de Saint Antoine e à primeira Éducation sentimentale), la partie historique je veux dire, je me suis imaginé que le scénario était fait et je m'y suis mis. Tout dépend du plan. (Carta de 31 de janeiro de 1852). 
Antes de encerrar essa seção, gostaríamos de tecer breves considerações sobre a cópia, haja vista essa ser considerada atividade menor, meramente reprodutiva nos autores citados.

Como vimos, a Tentação de Santo Antão teria sido inspirada pela tela homônima de Brueghel. No caso deste pintor, é sabido que a cópia reveste-se de um aspecto duplo, o aprendizado técnico e o estímulo à sensibilidade, na medida em que o olhar aprofundado e concentrado do objeto estético permitiria uma experiência exacerbada e o desenvolvimento da capacidade de observação do pintor. Aprendese a pintar copiando. A cópia seria, assim, uma possível preparação para a atividade criativa, reconhecida como tal entre pintores, músicos, literatos, em suas diferentes formas (cópia, réplica, pastiche).

Parece-nos que Flaubert, ao reiterar a cópia exercida por Bouvard e Pécuchet, não se refere apenas à Cópia, a reprodução incessante de tudo aquilo que já foi dito, mas tenta, isso sim, questionar "les représentations, idées recues, inquiétudes qui dérivent des sciences et constituent de nouvelles croyances pour un public indirectement informe et pourtant féru de science [...]" (Séginger, 2004). Em outras palavras, entendemos que a cópia relaciona-se à fragmentação do saber, pois essa fragmentação deve confrontar-se ao exagero de querer-se saber tudo ou ao desejo de generalização, ou seja, de aplicar o saber específico ao conjunto das experiências possíveis. No amplo campo dos saberes que desfilam ao longo de BP, busca-se a constituição de um conhecimento do mundo, tendo por base aquilo que já é sabido, colhido nas fontes mais diversas possível, nos livros, nos relatos de terceiros, nos lugares comuns e na experiência.

Ao copiar e (re)apresentar conhecimentos e opiniões, da mesma forma que o pintor que exercita sua sensibilidade, aquele que copia poderia - e esta não é afirmação absoluta - desenvolver sua capacidade de saber. Como todas as possibilidades de conhecimento levantadas até aqui, esta também é instável, mas a tensão entre essa possibilidade e sua realização efetiva pode ser vista como o conflito básico subjacente à narrativa, o tênue fio narrativo que permitiria ao leitor ter a sensação de que se defronta com um texto que não foge totalmente de suas expectativas, pois há uma necessidade de resolução dessa tensão que leva o leitor ao termo do texto; é fato que essa tensão não é efetivamente resolvida, mas essa seria a garantia da sensação de unidade do texto, de sua percepção como um todo e não apenas de uma série de fragmentos disparatados. 
Resumindo o raciocínio, parece-nos que, embora o leitor ria dos infortúnios de Bouvard e Pécuchet, é a diminuta possibilidade de que ambos possam alcançar uma redenção - o saber - que mantém o interesse da primeira parte do texto, aquilo que chamamos de "romance" até aqui. Por outro lado, a segunda parte, que inclui o dicionário, teria outra forma de coesão, que se relaciona com esta: acreditamos que seria a busca dessa mesma redenção, dessa vez em termos do esclarecimento, por meio de um conhecimento que parece mais organizado, pois classificado de forma perceptível, seja em ordem alfabética, seja na forma de categorias (ideias "chics", modelos etc), mas que leva ao mesmo desnorteamento: o "saber" apresentado não "explica". Cópia e repetição assumem, assim, papel fundamental no processo de significação do texto.

\subsubsection{CONTÍNUO/CATÁSTROFE}

O conhecimento em inglês supera de longe o conhecimento em espanhol, francês e português, somados. A estupidez anglófona também é maior que suas homólogas latinas. Pelo menos é o que acontece quando se faz uma busca dos termos equivalentes no Google ${ }^{44}$. A validade dessas "informações" é obviamente duvidosa.

Mesmo com o volume astronômico de informação colocado ao alcance de qualquer pessoa nos dias de hoje, sua credibilidade é baixa - num passado não muito distante, o nome de um autor, de uma editora ou a indicação de indivíduo dotado de "autoridade" servia como legitimação de conhecimento; hoje, com as urban legends, a disseminação viral de hoaxes, o frenético "copiar-e-colar", este mesmo processo torna-se muito mais delicado.

Assim mesmo, o computador e a lógica do hipertexto vêm alterando nossa escrita e nossa maneira de pensar. A The Atlantic Monthly, revista fundada por um grupo de intelectuais que incluía entre seus membros Ralph Waldo Emerson, publicou artigo de Nicholas Carr, com o sugestivo titulo "/s Google making us

\footnotetext{
${ }^{44}$ Busca realizada no mecanismo de busca Google (05 ago 2008) forneceu os seguintes resultados: "knowledge" (382.000.000), "conocimiento" (38.700.000), "connaissance" (25.200.000) e "conhecimento" (20.000.000); também foram pesquisadas as palavras "stupidity" (15.100.000), "estupidez" (3.690.000) e bêtise (2.020.000). Notar que "conhecimento" suplanta amplamente "estupidez" em todos os idiomas.
} 
stupid?", sobre essas mudanças, ainda insuficientemente exploradas. Em seu texto, Carr descreve a falta de concentração para ler textos mais longos experimentada por ele e por conhecidos, pessoas que se interessam por literatura, e atribui o fenômeno a essa modificação dos "hábitos mentais". Segundo ele, a ideia de que nossas mentes devem operar na velocidade da banda larga é tanto a base da rede como seu modelo de negócio dominante (Carr, 2008).

Com o advento das novas mídias e de novas possibilidades de comunicação, a busca da "quebra" do paradigma linear do texto, aqui compreendido em seu sentido amplo, semiótico, levou a várias experiências, algumas envolvendo o uso das capacidades propriamente técnicas e científicas, outras no campo das artes. Por um lado, temos o hipertexto, o texto formado por textos, que corrompe a ideia da leitura sistemática e que se tornou onipresente na comunicação eletrônica. Por outro lado, temos obras como Rayuela, de Julio Cortázar e experimentos oulipianos, que jogam com as possibilidades de escrita e leitura - solapando, além disso, os conceitos de autoria e de obra, posto que se realizam na atividade da leitura.

Para a elaboração ou explicitação desses conceitos, diversas metáforas têm sido empregadas, todas tomando como base a possibilidade da existência simultânea de conteúdos (ideias, conceitos e assim por diante). Entre essas metáforas, temos a biblioteca, a enciclopédia, e o hipertexto, o labirinto e o rizoma.

É interessante notar que Carr não menciona em seu artigo a geração de possibilidades de leituras não-lineares proporcionadas pelo hipertexto. Buscamos determinado assunto e, entediados ou satisfeitos com o saber superficial obtido, seguimos numa profusão de conexões não-hierárquicas e imprecisas, chegando a conhecimentos disparatados e, no mais das vezes, irrelevantes - "as larvas de um axolote reproduzem-se" - embora, ocasionalmente, possamos efetivamente descobrir algo que faça avançar nosso conhecimento ou que permita uma reflexão acerca de um problema, como o próprio artigo citado.

Se admitirmos que o hipertexto independe de seu meio físico, podemos considerar uma enciclopédia como uma de suas formas, com verbetes compreendidos, por exemplo, entre "aak" e "Zywiec", sem que necessariamente haja ao consultá-la um percurso linear determinado por uma lógica expressa facilmente discernível entre os verbetes consultados.

Sem discutir as questões relativas à especificidade de cada meio, o hipertexto apresenta, a meu ver, duas características fundamentais: em primeiro lugar, sua 
estruturação, ao permitir a leitura não-linear, faz com que o conteúdo do texto obtido (compreendido aqui como o conjunto das informações coletadas ao proceder-se a leitura, seguindo conexões que aprofundem ou divirjam do ponto inicial) não apresente uma estrutura hierárquica claramente decifrável entre os diversos subtextos que o compõem. A nosso ver - e assumindo nosso conhecimento limitado das pesquisas científicas na área - o hipertexto parece constituir metáfora bastante expressiva do funcionamento do cérebro humano, com suas associações às vezes aparentemente caóticas.

A partir da ideia de rizoma (Deleuze e Guattari, 1997), as infinitas possibilidades de leitura efetivamente obtidas entrecruzando-se de forma caótica, num espaço não delimitado e sem que haja um centro definido, pode-se sugerir uma forma complexa de labirinto, em que não haja ordem ou subordinação entre os caminhos escolhidos. Em segundo lugar, a questão da legitimação ou validade do texto obtido dessa forma representa problema complexo, com o qual lidamos cotidianamente de forma automática, atribuindo ou destituindo de prestígio essa ou aquela informação por meio de critérios vagos e/ou subjetivos. Temos, assim, "colagens" textuais formadas por blocos autônomos e independentes, cuja validade decorre do próprio arbítrio do leitor.

Da mesma forma que os verbetes de uma enciclopédia podem constituir-se enquanto hipertexto, podemos considerar a hipótese de um hipertexto formado por livros, conectados por vínculos virtuais, num espaço não limitado. Aqui, os trajetos possíveis podem ser representados por outro tipo de labirinto, aquele encontrado com frequência em parques de diversões, contando com uma entrada e uma saída, passagens "falsas" que nos trazem de volta ao ponto já percorrido, becos sem saída (o resultado pode ser visto como rizomático, mas o percurso assemelha-se mais ao labirinto típico, pois não há sobreposição de caminhos na leitura linear).

O leitor busca a informação, escolhe alguns volumes, hesita, devolve um ou outro para a estante, encontra referências e outras fontes de informação como quem busca seu caminho no labirinto - sem que se chegue necessariamente à saída. Caso nosso leitor seja dotado de perspicácia mediana e um mínimo de inteligência, procederá a uma hierarquização das obras consultados, construindo seu hipertexto bibliográfico por meio de referências, sugestões e, por que não, bom senso.

Em outras palavras, seu percurso textual será guiado por mecanismos de seleção e ordenação valorativa. O automatismo voraz do conhecimento em formato 
eletrônico, se não prescinde dessa coleção de processos, também incentiva seu enfraquecimento. Por que não seguir um vínculo ao acaso, já que é possível retornar ao mesmo ponto sem qualquer esforço? O problema é que clicar sobre uma palavra qualquer acaba por criar novas relações e um novo impulso (para onde?) e em questão de segundos o ponto de partida foi abandonado em função dessas relações.

Para o homem contemporâneo, imerso nos caminhos da (des)informação, saber torna-se parte inerente do ser, pois, como afina Ítalo Calvino em Seis propostas para o novo milênio,

Cada vida é uma enciclopédia, uma biblioteca, um inventário de objetos, uma amostragem de estilos, onde tudo pode ser completamente remexido e reordenado de todas as maneiras possíveis. (...) É bom pensar na vida, nas questões que perpassam nossa existência...

Falaremos do labirinto mais adiante. O conceito de rizoma é emblemático por sua anarquia inerente: não há início, nem final. Todos os pontos são rigorosamente iguais e podem, inclusive, assumir uma configuração multiplanar simultânea. Este seria um ponto-chave da metáfora do não-linear: a falta de hierarquia entre as possibilidades de existência simultânea faz com que seja impossível a própria ideia de uma chegada, de uma saída possível.

A enciclopédia, por sua vez, com seus verbetes organizados metodicamente, em ordem alfabética, poderia ser considerada como contando com uma forma de hierarquização entre seus verbetes. No entanto, o seguimento estrito dessa ordem, as referências cruzadas e a aparente neutralidade do ordenamento alfabético permitem que se diga que os verbetes são indiferenciados entre si. O leitor poderia, assim, iniciar sua "viagem" por uma palavra qualquer e prosseguir, por meio de associações mais ou menos livres, por quanto tempo se deseje.

A diferença principal entre o rizoma, o labirinto e a enciclopédia é a possibilidade da criação de uma saída de forma arbitrária: no momento em que desejar, o leitor pode abandonar sua leitura, sem que se sinta obrigado a prosseguir num "caminho" preestabelecido, ou seja, sem que se caia num impasse. Essa característica é partilhada com a biblioteca - neste primeiro momento, referimo-nos apenas à organização física da construção, sem levar em conta seu conteúdo; 
entretanto, a resolução do impasse na biblioteca é simples: basta abandonar a publicação que temos em mãos e buscar outra.

O ordenamento preciso, de acordo com métodos científicos, de materiais ("textos") heterogêneos acaba por conceder a esses materiais um caráter indiferenciado. As características são definidas pela construção de um objeto (seja o labirinto, seja a enciclopédia, seja a biblioteca), que gera implicações em seu uso: desnorteamento, no caso do labirinto, falta de objetivo, no da enciclopédia, e indecidibilidade, a impossibilidade de decidir, diante de uma massa de publicações que se apresentam de forma não-hierárquica, sem que haja uma orientação a respeito de quais dentre elas serão adequadas a determinado fim, exemplificada na biblioteca.

O hipertexto, por sua vez, parece reunir características do labirinto, do rizoma, da enciclopédia e da biblioteca. Temos nele a possibilidade do conteúdo simultâneo, indiferenciado - nada nos obriga a seguir (clicar em) determinado vínculo. Os textos de um grande portal, diferentemente diagramados e posicionados numa página na internet oferece opções de construção de conteúdo que, em princípio, são iguais. No entanto, o hipertexto também tem seu deus ex machina: o "navegante" pode parar seu percurso num momento qualquer e, principalmente, ao encontrar um impasse: a página não encontrada ou a busca que não deu resultados podem ser abandonadas e o percurso pode ser retomado aleatoriamente, em outra página e outra página. 0 jogo continua a ser jogado, independente do jogador.

O labirinto representa o avanço incerto, pela multiplicidade de opções que se colocam diante daquele que o percorre. Esse aspecto, da variedade de alternativas, pressupõe um conjunto a partir do qual essas escolhas são feitas. Uma primeira forma de indeterminação pode ser definida como uma lista, cujos elementos, em princípio, não se diferenciam. O emprego de listas é recurso amplamente empregado na literatura. Um exemplo curioso é encontrado no capítulo 31 do Quinto Livro, atribuído a Rabelais, em que é contada a história de um estranho personagem chamado Ouvir-dizer, que dirige uma escola de testemunhas. Sua descrição merece ser reproduzida:

Procurando então pelo dito país se alimento algum encontraríamos, ouvimos um ruído estridente e diferente, como se fossem mulheres lavando lixívia ou o ruído de moinhos de Bazacle lés Tholoze; sem mais nos demorarmos, rumamos para o lugar de onde vinha, e vimos um velhinho corcunda, aleijado e monstruoso. Chamava-se Ouvir-dizer; tinha a boca aberta até as orelhas, e dentro da boca sete línguas e cada língua fendida em sete partes; com todas elas 
falava ao mesmo tempo, apresentando diversos assuntos e em idiomas diversos; tinha também na cabeça e no resto do corpo tantos ouvidos quantos olhos tinha Argos; no resto, era cego e paralítico de ambas as pernas. (Rabelais, 1991, p. 359)

Um ser interessante, capaz de ouvir e falar infinitamente, por seus inúmeros ouvidos e pela língua multipartida, mas incapaz de ver e de se mover, parece uma alegoria do lugar-comum. Ao redor de Ouvir-dizer, as listas sucedem-se, numa das quais surge, segundo interpretação corrente, Pedro Álvares Cabral:

\begin{abstract}
Em torno dele, vi um número incrível de homens e mulheres ouvintes e atentos, e reconheci alguns entre a multidão de fisionomia alegre, e no meio deles um que tinha um mapa-múndi, e Ihes expunha sumariamente por pequenos aforismos, tornando-os assim doutos e sábios em poucas horas, e falavam de coisas prodigiosas elegantemente e com boa memória, pela centésima parte das quais não seria suficiente a vida do homem: pirâmides do Nilo, Babilônia, trogloditas, himantópoles, canibais, montes Hiperbóreos, egipãs, todos os diabos e tudo por Ouvir-dizer. Vi, segundo penso, Heródoto, Plínio, Solin, Berose, Filostrato, Mela, Estrabão e tantos outros antigos; mais Alberto o jacobino, Pedro Testemunha, papa Pio segundo, Volaterran, Paulo Jóvio o valente homem, Jacques Cartier, Chaiton armênio, Marco Polo veneziano, Ludovico romano, Pedro Alvarez e não sei quantos outros modernos historiadores escondidos atrás de uma peça de tapeçaria, escrevendo em tapeçanês belas descrições e tudo por Ouvir-dizer. (Rabelais, 1991, p. 360)
\end{abstract}

Cabe indagar: nesse caso, as listas seriam apenas instrumento para o riso, pelo efeito do exagero ${ }^{45}$, além, é claro, do jogo de palavras com o nome do personagem? Ou essas enumerações podem ser lidas numa chave irônica, em que a diferença entre os elementos, além de ser apagada, torna-se o veículo de uma reprodução irrefletida, já que Ouvir-dizer não podia ver por si, mas apenas repetir aquilo que ouvia?

Em Bouvard e Pécuchet, as listas adquirem outro aspecto, o nivelamento semântico ressaltando, a um só tempo, a impossibilidade de uma escolha e a necessidade de escolher, expressa na sucessão de temas que se tornam objeto de suas reflexões ou de seus interesses:

Ils faisaient des réflexions sur les pièces de théâtre dont on parlait, sur le gouvernement, la cherté des vivres, les fraudes du commerce. De temps à autre l'histoire du Collier ou le procès de Fualdès revenait dans leurs discours ; - et puis, ils cherchaient les causes de la Révolution. Ils flânaient le long des boutiques de bric-à-brac. Ils visitèrent le Conservatoire des Arts et Métiers, Saint-Denis, les Gobelins, les Invalides, et toutes les collections publiques. Quand on demandait leur passeport, ils faisaient mine de l'avoir perdu, se donnant pour deux étrangers, deux Anglais. (BP, p. 56).

\footnotetext{
${ }^{45}$ Spitzer, numa análise de Walt Whitman, opõe esse tipo de lista à enumeração caótica, que seria um procedimento "moderno".
} 
Na mudança para Chavignoles, surgem duas listas, que se opõem; a primeira, da mobília de menor importância e que será acompanhada, a partir de certo ponto, por Bouvard. Pécuchet acompanharia os objetos mais valiosos, enumerados na segunda lista, o que demonstra um cuidado consciente:

\footnotetext{
Les instruments de jardin, les couchettes, les matelas, les tables, les chaises, un caléfacteur, la baignoire et trois fûts de Bourgogne iraient par la Seine, jusqu'au Havre, et de là seraient expédiés sur Caen, où Bouvard qui les attendrait les ferait parvenir à Chavignoles. Mais le portrait de son père, les fauteuils, la cave à liqueurs, les bouquins, la pendule, tous les objets précieux furent mis dans une voiture de déménagement qui s'acheminerait par Nonancourt, Verneuil et Falaise. Pécuchet voulut l'accompagner. (BP, p. 63)
}

O cuidado classificatório, cheio de precauções, no entanto, mostra-se inútil. Devido às vicissitudes do trajeto, Pécuchet descobre que as taças de porcelana foram destruídas durante sua pequena odisseia pela província (BP, p. 64). Não basta ordenar e classificar, pois a realidade encarrega-se de tornar esse trabalho inócuo. Embora possa gerar o riso, a situação expressa no trecho também pode ser lida num tom trágico. O exagero rabelaisiano causa o riso, inclusive, por seu aspecto alegórico. A enumeração em Bouvard e Pécuchet forma uma base instável que exacerba a ambiguidade. Como os diversos caminhos que surgem diante daquele que entra num labirinto, não é a escolha que conduz à saída, mas a própria organização do labirinto.

\subsubsection{LABIRINTO: ESPAÇO GERAL DO SABER}

Et il demeura silencieux, acculé dans une impasse, conséquence des prémisses qu'il avait luimême posées. Ce fut une surprise, un écrasement. (BP, p. 295).

O trecho acima apresenta a única ocorrência da palavra "impasse" no romance póstumo de Gustave Flaubert, o qual, no entanto, apresenta-nos échecs sucessivos, situações que assinalam uma impossibilidade aparente de resolução, como no exemplo a seguir:

Vingt fois ils s'étaient levés, s'étaient rassis et avaient fait la longueur du boulevard depuis l'écluse d'amont jusqu'à l'écluse d'aval, chaque fois voulant s'en aller, n'en ayant pas la force, retenus par une fascination (BP, p. 50). 
Ou ainda:

Autrefois, ils se trouvaient presque heureux. Mais leur métier les humiliait depuis qu'ils s'estimaient davantage ; - et ils se renforçaient dans ce dégoût, s'exaltaient mutuellement, se gâtaient. Pécuchet contracta la brusquerie de Bouvard, Bouvard prit quelque chose de la morosité de Pécuchet.

— "J'ai envie de me faire saltimbanque sur les places publiques !" disait l'un.

— “Autant être chiffonnier" s'écriait l'autre.

Quelle situation abominable ! Et nul moyen d'en sortir ! Pas même d'espérance ! (BP, p. 57).

As menções a labirintos são mais frequentes, ligadas à ideia de desorganização e de multiplicidade: "La charmille ouverte çà et là donnait jour sur le bosquet, rempli d'allées sinueuses en façon de labyrinthe". (BP, p. 92). O labirinto reproduz o "avanço" de Bouvard e Pécuchet: "Après plusieurs détours dans le labyrinthe, on arriva devant la porte aux pipes". (BP, p. 98). Aqui, chega-se a uma saída, fechada por uma porta. Mas o labirinto também pode ser não um caminho, mas um espaço onde se perder é possível:

Et parlant au profil de Pécuchet, il admirait son port, son visage, "cette tête charmante", se désolait de ne l'avoir pas rencontré sur la flotte des Grecs, aurait voulu se perdre avec lui dans le labyrinthe. (BP, p. 195)

Retomando a ideia de desorganização, os hábitos contábeis de Bouvard o depauperam e é Pécuchet que se dá conta disso, chegando a uma verdade:

Le dommage était considérable, et pour se reconnaître dans leur situation, Pécuchet pendant huit jours travailla les registres de Bouvard qui lui parurent "un véritable labyrinthe". Après avoir collationné le journal, la correspondance et le grand livre couvert de notes au crayon et de renvois, il découvrit la vérité : pas de marchandises à vendre, aucun effet à recevoir, et en caisse, zéro ; le capital se marquait par un déficit de trente-trois mille francs. (BP, p. 86)

É curioso notar que, por meio do labirinto dos livros (contábeis), Pécuchet atinge o conhecimento (o saber), o que não the serve de nada. $O$ fracasso se mede, e é negativo.

Em sua tentativa pedagógica, o labirinto já deixou de ser uma possibilidade de caminho - para um novo fracasso -, mas algo que se deve evitar:

Victor confondait les hommes, les siècles et les pays.

Cependant, Pécuchet n'allait pas le jeter dans des considérations subtiles et la masse des faits est un vrai labyrinthe. (BP, p. 357). 
"Véritable" ou "vrai", o impasse e o labirinto estão sempre ligados ou ao avanço inútil, ou à possibilidade de um avanço impedido pela realidade comezinha.

No oitavo capítulo de Bouvard et Pécuchet, depois de deambular pela ginástica, por experiências místicas e pela magia, o objeto de interesse dos dois copistas passa a ser a filosofia. Nada mais sensato que começar pela concretude das causas materiais do êxtase e, necessariamente, pela compreensão da matéria (BP, p. 279). O percurso os leva indistintamente a ler filósofos "modernos" ou "do século passado". Até que Pécuchet, que acabara de descobrir Hegel, decide convidar o padre local para, após terminar seu discurso sobre o idealismo, saber a opinião do religioso. A conversação que se segue exaspera o cura, que se retira. Pécuchet sente-se vitorioso por sua crítica. Bouvard, no entanto, não consegue acompanhar o raciocínio de seu colega e acaba por expor suas objeções:

(...) On prend les idées des choses pour les choses elles-mêmes. On explique ce qu'on entend fort peu, au moyen de mots qu'on n'entend pas du tout ! Substance, étendue, force, matière et âme, autant d'abstractions, d'imaginations. Quant à Dieu, impossible de savoir comment il est, ni même s'il est! Autrefois, il causait le vent, la foudre, les révolutions. À présent, il diminue. D'ailleurs, je n'en vois pas l'utilité.

-"Et la morale, dans tout cela ?"

-"Ah! tant pis !"

-"Elle manque de base, effectivement" se dit Pécuchet. (BP, p. 295)

A busca do conhecimento pela palavra e pelo raciocínio lógico empreendida por Pécuchet tem o resultado que, embora esperado, surpreende e desanima 0 personagem, o impasse, levando por suas próprias premissas.

O processo cognitivo, de raciocínio por meio de constatações, percepções ou ações leva à impossibilidade de se prosseguir. Embora confrontados a esse resultado repetidamente, num método de Sísifo, por assim dizer, Bouvard e Pécuchet insistem no projeto, incansavelmente indo adiante, apesar dos empecilhos de diferentes naturezas que se opõem ao seu percurso.

Neste ponto, cabe empregar a ideia do labirinto como metáfora para ilustrar a situação. Mais que isso, e para melhor compreensão, é necessário explicitar o tipo de labirinto que temos em mente.

Antes de qualquer coisa, é interessante notar que na língua inglesa, ao contrário das línguas latinas (português, espanhol, italiano) e do alemão, existem dois vocábulos que definem a ideia de labirinto: "labyrinth" e "maze". A primeira refere-se ao labirinto encontrado na antiguidade, um conjunto intrincado de caminhos com entrada e saída. A ideia básica neste caso era mística: ao percorrer 
um trajeto (que podemos chamar de "linear", no sentido de ser dependente de um desenvolvimento sequencial) em que se é frequentemente desviado, mas que, inexoravelmente, levará ao ponto definido, poderia ocorrer a meditação e a entrega a valores superiores. Neste tipo de labirinto não encontramos becos sem saída ("impasses"); eles são percorridos sempre en avant e levam, inexoravelmente, a uma saída.

Já o vocábulo "maze", que, etimologicamente deriva de "amaze", "surpreender", "espantar", denomina aquele tipo de labirinto que conhecemos dos parques de diversões: temos um conjunto complexo de caminhos e de possibilidades de percurso, alguns dos quais são interrompidos - ou seja, não permitem o avanço. Este tipo de labirinto, parece-me, tem sido empregado como metáfora de formas não-lineares de conhecimento e/ou leitura. Diferentemente do primeiro tipo, no escuro deste labirinto não há iluminismo possível. Em outras palavras: não há percurso pré-definido e o avanço pode dar-se à reculons. Chegarse à saída desta estrutura pode implicar em concessões (recuos) que se sucedem a avanços que apenas podem ser reconhecidos uma vez efetuado o trajeto. É uma viagem em que o caminho é conhecido somente quando o porto é atingido.

O que define o labirinto não é o percurso, mas sua estrutura intrínseca, a qual, por sua vez, não possui significado em si mesma, mas apenas e tão somente na atividade de percorrê-lo, surpreendendo e espantando. O labirinto, no dizer de Jorge Luis Borges, "é uma casa edificada para confundir os homens; sua arquitetura, pródiga em simetrias, está subordinada a esse fim" (Borges, 1998, v. 1: p. 598). A confusão gerada por esta estrutura, no entanto, permite vislumbrar a possibilidade da descoberta e da busca. Apenas aquele que procede em seus ramos e bifurcações pode contar com a possibilidade de uma saída. Encontrá-la pode depender apenas do acaso, mas, como nos mostra o mito de Teseu, também pode ser fruto da invenção - do fio de Ariadne, que permite dar ordenação quase linear ao percurso. É neste choque entre o (caminho) desconhecido e a criação que o labirinto surge como metáfora rica, e aplicável à realidade do período que vai do final do século 19 ao final do século 20, fase de guerras, de revoluções e de descobertas que modificaram a face do planeta e que revelaram ao homem, pela primeira vez, sua capacidade de destruir a própria espécie e todo o mundo conhecido.

Retomando-se a definição de labirinto dada por Borges, é possível amplificála e identificar elementos básicos. Em primeiro lugar, está a noção de edificação, ou 
seja, de uma construção feita com um objetivo determinado, o de causar a confusão. Esta construção é constituída por uma rede de caminhos possíveis e é a maneira pela qual esses caminhos estão dispostos que torna difícil a orientação em seu interior, levando à desorientação. Borges, no entanto, não explicita a forma pela qual essa desorientação se dá, atribuindo-a à simetria da construção, que, aos olhos daquele que o percorre, não apresenta ordem e/ou clareza. Trata-se de uma construção vista como complicada ou intrincada não do ponto de vista arquitetônico, mas do ponto de vista daquele que busca, com ou sem sucesso, chegar à saída. É buscada uma solução que permita o ordenamento racional, a linearização do percurso, mas não há caminho - e não basta caminhar para encontrá-lo. Busca-se a saída, um resultado favorável, mas encontra-se o beco sem saída, o impasse.

Jeanne-Marie Gagnebin, falando sobre Walter Benjamin, dá uma ideia interessante acerca do labirinto:

Metáfora ao mesmo tempo das relações temporais entre presente, passado e futuro e das relações privilegiadas que o sujeito entretém consigo mesmo pelos descaminhos do amor, das viagens, da leitura e da escrita. (GAGNEBIN, 1999, p. 76)

A filósofa introduz um elemento temporal: a metáfora condensa relações entre tempos disjuntos e o próprio fluxo dos acontecimentos vividos.

Seria interessante pensar nessas relações em termos do impasse e da impossibilidade de se tomar uma decisão: o homem moderno não conta mais com a certeza que num determinado momento foi oferecida pela religião, pela ciência ou pela ideologia e deve escolher entre alternativas que cada vez mais acabam sendo apenas mais um corredor rumo a novo impasse. Sem que possamos recorrer às soluções do mito:

Qual a estratégia do navegante para avançar no labirinto? A mitologia apresenta duas alternativas. A primeira é o fio de Ariadne, que marca os lugares já percorridos para garantir a volta. $\mathrm{Na}$ verdade, o fio de Ariadne visa combater a complexidade do labirinto através de sua linearização: em vez de enfrentar o labirinto em suas sinuosidades e em suas bifurcações, como faziam os cretenses em suas festas, o grego Teseu, com o fio de Ariadne, retifica o labirinto, unifica o percurso e une começo e fim. A segunda alternativa - a dança dos gêranos é mais poética e inteligente. Rapazes e moças alternados e com as mãos dadas em fila simulam o percurso do labirinto através de uma dança típica. Há um guia em cada uma das pontas da fila, o que significa que eles podem correr em qualquer um dos sentidos. Diante de uma encruzilhada, o grupo pode percorrer simultaneamente as duas alternativas, cada guia puxando o grupo para cada uma delas. Caso uma das alternativas não tenha saída, o guia que se defronta com essa alternativa dá um grito e é logo compreendido por seus companheiros: a fila passa a ser dirigida então pelo outro guia até a próxima encruzilhada. (...) A ideia de optar simultaneamente por todas as alternativas marca a diferença da dança dos gêranos em relação 
ao fio de Ariadne. A beleza e a astúcia da estrutura do labirinto estão na multiplicação das possibilidades e na vivência dos tempos e espaços simultâneos". (Machado, 1997, p. 151).

Não temos a possibilidade de optar por todas as alternativas possíveis ao mesmo tempo - cabe até a pergunta: e se houvesse três caminhos diante do grupo de dançarinos? Como fazer?

O labirinto, lugar feito para que o indivíduo "se perca", também permite a busca de si e a exploração de limites. Temos, pois, além das características citadas anteriormente, da construção, da não-hierarquização das alternativas, do caráter temporal e da imperatividade da escolha, também a busca do conhecimento (a "saída") como constitutiva dessa metáfora.

Literariamente, ele pode ser visto como metáfora de uma estrutura que desafia a tradição. Aquele que escreve abandona as poéticas normativas, que definem aquilo que pode e o que não pode ser feito e passa a criar, e a invenção que emprega como ingrediente o material linguístico, e não mais a narrativa e os acontecimentos, ganha autonomia.

Mais que afirmar uma característica da narrativa moderna, Robbe-Grillet situa em Flaubert seu fundamento:

Mais voilà que, dès Flaubert, tout commence à vaciller. Cent ans plus tard, le système entier n'est plus qu'un souvenir ; et c'est à ce souvenir, à ce système mort, que l'on voudrait à toute force tenir le roman enchainé. (idem, p. 31).

Para o autor de La Jalousie, portanto, a atividade da escrita de ficção, e, mais especificamente, do romance, sofre uma inflexão, pois narrar torna-se impossível (idem, p. 31). Os acontecimentos deixam de constituir o fio narrativo. A relação entre episódios distintos se dá pela negação, pela impossibilidade de se lhes atribuir um valor positivo, o que se dá de forma extremada na prosa de Samuel Beckett. 


\subsection{PONTOS DE PARTIDA}

\subsubsection{OS HOMENS E SEUS DUPLOS - LABIRINTO NA NARRATIVA}

En un lugar de la Mancha, de cuyo nombre no quiero acordarme, no ha mucho tiempo vivía un hidalgo de los de lanza en astillero, adarga antigua, rocín flanco y galgo corredor.

Célebre, o início do primeiro Dom Quixote, de Cervantes, surgido em 1605, serve como apresentação geral do texto com o qual o leitor terá de se haver do momento em que se inicia a leitura em diante. Diversos elementos são apresentados: sobre quem se fala (um fidalgo), onde a ação tem início (la Mancha) e como ele é (ou seja, faz-se uma breve caracterização). O narrador introduz-se no texto, ao afirmar que não irá ou que não consegue lembrar-se do nome exato do local em que a ação inicia-se ${ }^{46}$. Temos, assim, um microuniverso delineado. O leitor tem dados que fundam sua percepção do texto. Esse início apresenta, além de uma prática tradicional, o estabelecimento de uma preparação para um processo, o da leitura. Institui-se uma relação entre o "desocupado leitor", o narrador e o relato a ser feito, o que sugere certa estabilidade desta relação, confirmada pela sequência do período, que descreve o aspecto pacato e sem relevo do fidalgo. O leitor vai ao encontro da narrativa, relacionando-se, pelo encadeamento e pela fundamentação lógica do desenvolvimento, que leva a uma sensação de quase inevitabilidade.

A este encadeamento lógico e determinado pode-se associar um racionalismo renascentista e uma preocupação com a forma ligada ao barroco. Ideologia e prática estabelecem, deste modo, uma visão do mundo ligada a um contexto marcado. Narrador, forma, conteúdo e leitor encontram-se imbricados numa relação de dependência e confronto, de papéis marcados e relacionados entre si.

Realizando-se um salto no espaço e no tempo, temos, na França, outra prática de encetar a relação (dialógica) entre leitor e texto:

\footnotetext{
${ }^{46} \mathrm{O}$ que poderia também constituir um lugar-comum.
} 
Comme il faisait une chaleur de trente-trois degrés, le boulevard Bourdon se trouvait absolument désert. (BP, p. 47).

O trecho começa por uma conjunção causal ("comme"). Sugere uma conclusão lógica, um encadeamento necessário. Em outras palavras: se "A" ("faz trinta e três graus"), então "B" ("a rua encontra-se deserta"). Mas tal conclusão, a urgência - no sentido daquilo que é indispensável - provocada pelo calor que cai, literalmente, no vazio, pode ser desmontada ${ }^{47}$ : qual a base para esta afirmação ${ }^{48}$ Não são apresentados outros elementos (nesse momento) que permitam que ela seja corroborada. Como saber se não se trata de uma falácia? A ausência de pessoas poderia ser devida ao fato de se tratar de, por exemplo, um feriado (mais tarde, saberemos tratar-se de um domingo). De mais a mais, não sabemos (lembrar que somos leitores de além-mar, situados a mais de um século do contexto original da obra) ser tal fato normal. Fosse a temperatura mais baixa, o bulevar estaria vazio? Existe algum atrativo nele que sugira sua ocupação? Estaríamos diante de uma instância da incapacidade da afirmação, citada por Flaubert em sua correspondência? Como dizer o que quer que seja, se não existe forma nem fundamento adequado para fazê-lo? $\mathrm{Na}$ aparente simplicidade, o estranhamento dissolve ("derrete") a certeza, o nexo causal.

O leitor mais interessado em narrativas "clássicas", que deseja

(tornar-se) então semelhante a um espectador de cabaré que subisse ao palco e apressasse o strip-tease da bailarina, tirando-lhe rapidamente as roupas, mas dentro da ordem, isto é: respeitando, de um lado, e precipitando, de outro, os episódios do rito (qual um padre que engolisse a sua missa). (Barthes, 1973, p. 19)

poderia não cair nessa aporia impeditiva ${ }^{49}$. Seguiria a leitura, aguardando um desenvolvimento narrativo.

\footnotetext{
${ }^{47}$ E não "desconstruída", ressalto.

48 Sigo esta argumentação para demonstrar a insegurança da afirmação, ou seja, trato de desautorizá-la.

${ }^{49}$ Aliás, cabe notar que na dialética aristotélica a aporia é fonte de compreensão filosófica:
}

A elucidação entre teoria do conhecimento científico e a dialética permite que se lance uma luz diferente sobre os tratados vários que compõem o corpus aristotelicum. Eles não se apresentam como cadeias silogísticas dedutivas, o que neles Aristóteles habitualmente nos expõe são "os meandros de sua investigação (dialética) em marcha, o lento tatear do trabalho preliminar de pesquisa", os argumentos de vária natureza, mais ou menos conclusivos, por vezes entre si contraditórios, de que lançou mão para estabelecer seus princípios e premissas. Mostra-se então como um grande número de estudiosos e comentadores, porque não compreenderam a complementaridade entre dialética e ciência, se vêem obrigados a 
Talvez estejamos estirando para além da conta o arco deste questionamento. Afinal, num contrato tácito hipotético entre aquele que cria o texto e aquele que o lê, cabe supor um sequência da leitura; aquilo que não está dito no primeiro parágrafo será (supõe-se) melhor entendido ulteriormente. Não seria necessário, assim, tentar esmiuçar tão detidamente as quinze primeiras palavras de um texto que consumiu a leitura de mil e quinhentos volumes em sua fatura. Como entender esse primeiro trecho: como mera introdução a um discurso coerente que irá se seguir ou (já) como indício do problemático que se desenvolverá ao longo do texto?

Jean-Paul Sartre afirma que

\begin{abstract}
Ler implica prever, esperar. Prever o fim da frase, a frase seguinte, a outra página; esperar que elas confirmem ou infirmem essas previsões; a leitura se compõe de uma quantidade de hipóteses, de sonhos seguidos de despertar, de esperanças e decepções; os leitores estão sempre à frente da frase que leem, num futuro apenas provável, que em parte se desmorona e em parte se consolida à medida que a leitura progride, num futuro que recua de uma página a outra e forma o horizonte móvel do objeto literário. (Sartre, 1989, p. 35-36)
\end{abstract}

O leitor deve, assim, "ir além da coisa escrita" (Sartre, 1989, p. 38), buscando, por meio de sua subjetividade, criar o objeto literário.

É interessante notar que em outros textos de Flaubert o incipit estabelece espaços e tempos de forma precisa, fornecendo elementos que contribuem para introduzir a narrativa. Se por vezes temos data, local e situação precisos (no dia 15 de setembro de 1840, por volta das seis da manhã, o "Cidade de Montereau" prepara-se para partir ${ }^{50}$ ), o parágrafo inicial de Madame Bovary descreve a chegada de Charles, indo ao nível do detalhe: "Ceux qui dormaient se réveillèrent, et chacun se leva comme surpris dans son travail" (MB, p. 23). Certo "efeito de real"51 insinuase na abertura de Salammbô, pois somos de saída informados, quase como uma advertência, que "C'était à Mégara, faubourg de Carthage, dans les jardins d'Hamilcar." Digno de nota é o fato de que na Educação e em Salammbô temos a delimitação de espaços ligados à cidade (Paris, como também é o caso em $B P$, e Cartago). O primeiro parágrafo de CS refere-se a uma cidade menor (Pontl'Évêque). HER e LSJH apresentam espaços que poderíamos denominar míticos,

postular oposições desnecessárias entre a teoria da ciência e a prática da ciência em Aristóteles. (Giannotti, 2001, p.19)

\footnotetext{
${ }^{50}$ Seguindo, note-se, contra a corrente.

${ }^{51}$ Refiro-me ao artigo de Roland Barthes.
} 
colocados que estão num passado do qual estamos afastados o suficiente para considerá-lo imemorial. Em $B P$, esse espaço é quase palpável.

A caracterização do espaço aprofunda-se. O parágrafo estrutura-se de forma a encadear esses detalhes ("Plus bas", "sur la berge" e assim por diante). Surge, no entanto, um aspecto de delimitação, com lugares fechados e recipientes. Duas eclusas fecham o canal, a jusante e a montante; as águas do canal, incidentalmente, têm a cor de tinta - e um rio de tinta é o trabalho que Flaubert se impõe (cf. correspondência). As eclusas, no entanto, impedem que esse fluxo de tinta se escoe no Sena, ou seja, no mundo, o que parece ecoar os bloqueios sofridos durante a escrita:

Quant à moi, ça ne va pas ! Ça ne va pas du tout ! B. et P. sont restés en plan. Je me suis lancé dans une entreprise absurde. Je m'en aperçois maintenant, et j'ai peur d'en rester là. Je crois que je suis vuidé. (Carta para Ivan Tourgueniev, 3 de julho 1875).

Plus bas le canal Saint-Martin, fermé par les deux écluses étalait en ligne droite son eau couleur d'encre. II y avait au milieu, un bateau plein de bois, et sur la berge deux rangs de barriques.

No meio do canal, um barco - outro lugar fechado - carrega madeira. Duas filas de barricas, recipientes fechados, estão dispostas sobre a margem. Parece surgir um aspecto de indiferenciação: espaços fechados, o canal, o barco, os barris, todos englobam conteúdos homogêneos: madeira, algum tipo de líquido (hoje, poderíamos dizer tratar-se de commodity) e as águas escuras.

A necessidade de vazão represada pelas eclusas e pelas barricas, num quadro estático, num dia quente e sem que haja qualquer personagem, ao mesmo tempo em que gera pequena tensão, dá ao espaço um aspecto inaugural, quase teatral, tendo em vista também o fato de que o espaço mais amplo do bulevar também surge como delimitação.

A descrição funciona como a abertura das cortinas antes de uma ópera; ao leitor/espectador é concedido um tempo para apreciar o pano de fundo diante do qual o verdadeiro objeto, indissociável, no entanto, desse mesmo fundo, irá se desenrolar. Não se trata apenas de expor um cenário em que a narrativa irá se 
desenvolver, mas já está criada uma micronarrativa, na qual não há possibilidade de desenlace aparente.

Tudo conspira para a fixidez, o calor, as eclusas, a embarcação, as barricas, tudo absolutamente imóvel. Um cenário teatralmente montado para a entrada dos personagens, teatralidade exacerbada pela cuidadosa construção rítmica do texto, como o contraste entre /z/ e /J/ (faisait/chaleur), a repetição do /t/ ("trent trois dégrés") e do /b/ ("boulevard", "Bourdon", "absolument"), a síncope em "Bourdon”, "resolvida" em "trouvait" e o alongamento da sílaba final da segunda oração. Estamos próximos do poético de Meschonnic e do ouvir de Pound: o aspecto aural do texto, se nos é permitida a generalização, é fundamento de seu sentido. O parágrafo encontra nele mesmo sua "justificativa”, graças a uma estrutura rítmica elaborada.

Do ponto de vista lógico, entretanto, não há a mesma sustentação. Nem mesmo a metáfora da página escrita, a água "cor de tinta" limitada (novamente) pela margem (noção de limite) sugere uma possível saída, pelo seu represamento.

As evidências de um trabalho prolongado com a substância do texto afloram nos vários níveis possíveis de leitura, o processo na "câmara escura" da criação, descrito por Mario Vargas Llosa:

\begin{abstract}
A página vai se cobrindo de emendas, acréscimos, repetições, camadas superpostas de palavras que chegam a fazê-la incompreensível. Então passa a limpo a limpo nessa página em que não tocou até agora. Avança muito devagar e esta nova versão é submetida à prova de gueuloir, que seria mais exato chamar do ouvido. Sua convicção é a seguinte: só se consegue uma frase com a musicalidade perfeita. (...) Se não soa bem, se não é melodiosa e envolvente, se suas virtualidades sonoras não constituem em si mesmas um valor, não é correta, as palavras não são as exatas e a "ideia" não foi cabalmente expressa. Assim vão se acumulando as folhas, de duas em duas: uma face de uma é a primeira versão do verso de outra. Um bom dia de trabalho pode significar meia página definitiva; mas há jornadas dedicadas a compor - é o verbo preciso - uma só frase. (Llosa, 1979, p. 67).
\end{abstract}

A análise deve, no entanto, ir além da mera reprodução do mecanismo técnico por meio do qual o efeito estético do texto é alcançado. Ao contrário do que afirma Whiterill $^{52}$, não se busca esclarecer os objetivos de Flaubert, compreendido aqui como o autor "de papel", ao escrever; a leitura deve buscar se sustentar por si, extraindo do diálogo com o texto e do esforço de escrita um novo texto, internamente

\footnotetext{
${ }^{52}$ Étudier la manière dont Flaubert lisait et la façon dont il réagissait devant les œuvres d'autrui nous permettra de donner une valeur relative aux aspects différents de ce que l'on appelle, faute de mieux, son esthétique, ce qui, à son tour, facilitera l'appréciation de son art : savoir ce que Flaubert approuve ou désapprouve chez autrui, n'est-ce pas en quelque sorte mieux comprendre les buts de Flaubert en écrivant ses romans? (Whiterill, 1964, p. 12).
} 
justificado - no ponto de contato com o texto com que se dialoga - e baseado em múltiplos pontos de vista. 


\section{DISPOSITIVOS E CONFIGURAÇÕES DO IMPASSE}

\subsection{CAMPO DE ACUMULAÇÃO}

\subsubsection{A ENCICLOPÉDIA COMO PROJETO}

Enfin, tous les faiseurs de rhétoriques, de poétiques et d'esthétiques me paraissent des imbéciles ! (BP, p. 207)

As complexidades do projeto de BP emanam já na correspondência de Flaubert. Basicamente, a história de dois homens que copiam parece tarefa relativamente simples, mas, ao tentar explicitar sua intenção, atribui à sua ideia a denominação de "enciclopédia crítica em farsa".

Depreende-se daí que se trate de uma exposição metódica de conhecimento humano (de um "saber" ou de "saberes"), que estabelece um juízo de valor e, além disso, com fundo cômico. Projeto, como se vê, que pode ser relacionado à ideia da Encyclopédie ou Dictionnaire raisonné des sciences, des arts et des métiers de Diderot e d'Alembert, obra da burguesia ascendente do século 18, com base no espírito filosófico, cientificista e crítico da época. Enciclopédia ou dicionário? Enquanto a primeira dedica-se à exposição de conhecimentos, o segundo parece referir-se de maneira mais próxima à catalogação lexical, centrada em torno de um tema ou ramo do conhecimento.

É interessante comparar essa concepção inicial do projeto com o verbete Encyclopédie, no DIR: "En rire de pitié, et même tonner contre comme étant un ouvrage rococo".

Ao descrever os assuntos aos quais irá se dedicar ao longo dos anos que se seguiriam, Flaubert sugere um deslocamento do interesse sugerido (a cópia) para um foco mais definido para o projeto, pois, para empreendê-lo, será necessário estudar química, medicina, agricultura, enfim, temas que o escritor desconhece, embora já em 1872 estivesse se dedicando ao estudo da Medicina, tema ao qual já se havia debruçado anteriormente e fato relevante de sua biografia. É sugerido, 
assim, o âmbito de um conjunto de saberes, aproximando-se mais da ideia de enciclopédia.

Numa carta de 19 de agosto de 1872, Flaubert fala de seu projeto de uma "encyclopédie critique en farce". Charles Bernheimer descreve-o desta maneira: "The book is structured not according to an organic unfolding but in the discontinuous form of an unalphabetized encyclopedia." (Bernheimer, 1994, p. 147). Também Hugh Kenner associa a estrutura da obra à de uma enciclopédia, criada por um "comediante do lluminismo" (Kenner, 2005). Entretanto, os "verbetes" que surgem ao longo do romance (na falta de expressão melhor) são apenas a chave de acesso ao que pode configurar uma metáfora mais rica, o labirinto, com suas idas e vindas e becos, no qual os ramos do conhecimento, igualados pela falta de nexo causal entre eles (numa obra que começa com uma conjunção causal), adquirem o mesmo valor relativo das obras e opiniões que assumem o lugar da realidade para os dois copistas (cf. abaixo). Flaubert, como Brown nota, citando Sartre, não é um filósofo, pois

(...) he found it difficult to decide rationally between philosophical positions: "Si les idées adéquates ne sont pas marquées, comment les reconnaitre? Tout s'équivaut. Et Gustave nous fera savoir qu'il 'n'a pas d'idées', qu'il ne faut jamais conclure, qu'il faut respecter toutes les opinions pourvu qu'elles soient sincères." According to Sartre, Flaubert's passivity debars him from a fully 'active' (and thus Spinozan) use of his reason, leading instead to a baffled scepticism, Flaubert's "doute absolu". "Tel est Gustave : réceptacle de sentences déposées par Autrui, apprises par cœur, éprouvées comme aliénation donc crues, il se trouve en un monde où la Vérité est l'Autre". Philosophy may inspire but it does not allow Flaubert, in that telling phrase, to make up his mind. (Brown, 1996, p. 850-851).

Entretanto, essa busca impossível do sentido, ou melhor, a onipresença da incerteza, permite que questões sobre a vida sejam levantadas:

\footnotetext{
Flaubert himself termed Bouvard et Pécuchet a "philosophical" novel and it is so in the most modern, post-Wittgensteinian sense of that term: it constitutes an investigation into the nature and status of language in respect to reality and to truth. The question of the clerks' relative intelligence or stupidity, which has so vexed psychologizing critics over the decades, remains obscure because Bouvard and Pécuchet are merely the instruments through which Flaubert illustrates the epistemological insufficiency of metaphor, not characters with analyzable symptoms. Their movement from discipline to discipline is not motivated psychologically so much as it reflects the movement of language itself in its symbolic and discontinuous relation with reality. (Bernheimer, 1974).
}

Bernheimer analisa longamente a forma pela qual Flaubert "borra" qualquer hierarquia entre os elementos textuais, fazendo com que por vezes o leitor fique em dúvida a respeito da fonte de algumas afirmações, assim como a respeito da 
identidade daquele que as emite e por meio desse procedimento, "(by) detaching each fact from any interpretive framework he restores it to what he considers its ontologically pure status" (op. cit.). As listas e enumerações funcionam de maneira a colocar cada elemento num patamar único de importância (ou de indiferença, nas palavras de Bernheimer). Os "caminhos" desse labirinto são todos iguais. Apenas numa saída hipotética sabe-se que uma escolha correta foi feita, mas, a menos que seja utilizado um fio de Ariadne narrativo, não se pode percorrer o mesmo caminho novamente - a rigor, não se tem sequer a noção exata do percurso percorrido (lembrando que, para Flaubert, o importante no caso de Bouvard e Pécuchet era a visão de conjunto). Pior, a saída pode ser a própria entrada. Depois de perambular por corredores indiferenciáveis, descobrir-se que chegamos ao mesmo lugar. Resultado desanimador.

No labirinto dos livros, na refração de um tempo que em sua inocência não resolve seu problema fundamental, o romance póstumo de Flaubert coloca a pergunta que não foi ainda respondida, a causa de nossa infelicidade, expressa dessa forma no final do século 20:

\footnotetext{
Acho que é a conquista da natureza pelo homem, até onde vai, e vai longe, muito mais do que qualquer pessoa da era de Sófocles ou Shakespeare podia imaginar, que nos faz tão infelizes, porque não conquistamos a morte. Shakespeare dizia que seus versos viveriam mais do que os palácios de mármore. Mas nem ele previu a fissão nuclear, o fato de que podemos destruir inapelavelmente toda a criação e que esse gênio destrutivo não consegue nos salvar, a um único ser humano, do oblívio, dos sete palmos abaixo, do incinerador, dos full fathom five. Não posso acreditar que minha lucidez um dia não exista mais, insuficiente como a considero, mas é minha, é o que sou, e Heidegger tem razão, esse estupro tecnológico a que submetemos a natureza nos tirou a serenidade diante da morte que Shakespeare tinha e imortalizou em A Tempestade". (Francis, 1994, p.66).
}

Do cardápio aparentemente infindável - na forma aberta da obra, entre o encontro de Bouvard e Pécuchet e o retorno à cópia, seria possível incluir uma miríade de episódios, num labirinto infinito - da acumulação, essa sim enciclopédica, de teorias disparatadas, ficamos apenas com o gosto da impossibilidade (e talvez até da inutilidade) do conhecimento. Enquanto submete o real aos seus desígnios estéticos, Flaubert, além de não nos mostrar uma saída, nos dá a impressão de que nenhuma saída é possível, como diz Maupassant:

C'est la tour de Babel de la science, où toutes les doctrines diverses, contraires, absolues pourtant, parlant chacune sa langue, démontrent l'impuissance de l'effort, la vanité de l'affirmation et toujours I' "éternelle misère de tout". (BP, p. 446) 
É válido, deste modo, reter a visão de montagem significativa, mas parece-me ser mais interessante elaborar a leitura do texto como uma série de impasses, entendidos como situações aparentemente ${ }^{53}$ sem solução. Além disso, essas situações decorrem de possibilidades de escolhas num universo dado - e é somente a partir do impasse que há uma ruptura em relação a este universo. Não necessariamente uma ruptura brusca, um salto ao acaso para fora do campo de possibilidades de associação semântica; por vezes, esse salto apresenta uma estreita ligação com o impasse anterior:

On recommande formellement de choisir un classique pour se mouler sur lui mais tous ont leurs dangers - et non seulement ils ont péché par le style - mais encore par la langue.

Une telle assertion déconcerta Bouvard et Pécuchet et ils se mirent à étudier la grammaire. (BP, p. 203)

O impasse, que anteriormente havia sido produzido pelo desvelamento das incorreções encontradas nos romances históricos pela obra de referência, é encontrado pelo desacordo entre especialistas, pela palavra que deveria ser a fonte de uma certeza possível:

Les grammairiens, il est vrai, sont en désaccord ; ceux-ci voyant une beauté, où ceux-là découvrent une faute. Ils admettent des principes dont ils repoussent les conséquences, proclament les conséquences dont ils refusent les principes, s'appuient sur la tradition, rejettent les maîtres, et ont des raffinements bizarres. Ménage au lieu de lentilles et cassonade préconise nentilles et castonade. Bouhours jérarchie et non pas hiérarchie, et $\mathrm{M}$. Chapsal les œils de la soupe. (BP, p. 203-204)

Não é necessário ressaltar o eco do percurso narrativo do capítulo: o contraste entre a beleza e o erro, a contradição entre princípios e consequências, a recusa da tradição e as idiossincrasias reproduzem os questionamentos anteriores. Como num labirinto, temos a impressão da necessidade de voltar sobre os próprios passos, a fim de encontrar um caminho frutífero. Que, no caso dos personagens, adquire um caráter niilista: "Ils en conclurent que la syntaxe est une fantaisie et la grammaire une illusion." (BP, p. 204). A recusa do avanço constitui um novo caminho. A questão é: o que fazer com o percurso seguido até então?

\footnotetext{
${ }^{53} \mathrm{Na}$ medida em que uma solução sempre é possível: ignorar-se o impasse, o que não significa que ele deixe de existir; a escolha de um novo caminho no labirinto não destrói o anterior, este passa a fazer parte do percurso que será parte do "efeito de conjunto" do trajeto.
} 
Passa-se à estética e, numa passagem que lembra o monsieur Jourdain de Molière, temos a busca de uma definição do Belo:

- "Je comprends" dit Bouvard "le Beau est le Beau, et le Sublime le très Beau."

Comment les distinguer?

- "Au moyen du tact" répondit Pécuchet.

— "Et le tact, d'où vient-il ?"

— "Du goût !"

— "Qu'est-ce que le goût ?"

On le définit un discernement spécial, un jugement rapide, l'avantage de distinguer certains rapports.

— "Enfin le goût c'est le goût, — et tout cela ne dit pas la manière d'en avoir." (BP, p. 206)

Existe, em toda a passagem, brevemente analisada (v. 2.2.1. adiante), entre as leituras de Walter Scott e as considerações sobre a estética, uma progressão narrativa que apresenta como elemento estruturante o impasse, pois é ele que permite a interferência de novos discursos e, em consequência, o avanço da narrativa, o que permitiria, em princípio, sua continuidade ao infinito. É uma possibilidade. Como afirmado anteriormente, não é possível saber com certeza qual seria o aspecto do texto finalizado - o que possivelmente contradiria essa possibilidade. A reflexão que julgo importante é pensar na lógica que poderia conduzir a narrativa a um fecho ${ }^{54}$, virtual ou real, que se relacionasse com seus elementos, dando, assim, lugar a uma leitura de conjunto. É nesse sentido que a metáfora do labirinto parece-me bastante rica, pois seria capaz de sugerir um objeto de estudo, composto de impasses e possibilidades ${ }^{55}$, que fazem sentido apenas enquanto totalidade. Aqui, será necessário, apesar da constatação de Bouvard, seguir na construção daquilo que poderia ser descrito como uma poética.

Com frequência, somos confrontados em Bouvard e Pécuchet com situações marcadas pelo acontecimento inopinado, repentino, ou pela coincidência inverossímil. Exemplo do primeiro caso é o surgimento de ambos, no início do primeiro capítulo. Eles apenas surgem, sem que nenhuma outra informação seja dada; lembrando a análise que Auerbach faz de uma passagem bíblica em Mímesis (Auerbach, 2004, p. 3 e ss.), o leitor, embora nutra certas expectativas, não é, efetivamente, informado sobre detalhes daquilo que acontece. Em Bouvard, apenas

\footnotetext{
${ }^{54}$ Novamente, falamos num fecho da narrativa que não se confunde com um fechamento do texto, com o esgotamento de suas possibilidades de leitura.

${ }^{55}$ Além do campo de possibilidades gerados na narrativa, há também o jogo de possibilidades relacionados à expectativa do leitor; se há a repetição, modificada, do mesmo motivo, o leitor pode começar a tentar prever esse "desenvolvimento".
} 
dois homens, sem adjetivos que, de alguma forma, possam auxiliar o leitor em sua busca de algum sentido, aparecem. Além disso, a passagem dos parágrafos anteriores, que descrevem o Bulevar Bourdon e seu triste dia de verão (um aparente paradoxo: "Été: toujours exceptionnel" ${ }^{56}$ ), para a súbita irrupção dos dois personagens ganha importância, na medida em que os dois copistas precisam entrar em cena (e a alusão teatral é proposital) para que a narrativa possa continuar seu percurso. Não importam razões ou relações, ambos apenas surgem. A importância desse acaso encontra-se em seu aspecto de coincidência. Num local deserto, dois homens surgem ao mesmo tempo. Ao chegar ao meio do bulevar, sentam-se no mesmo banco e, como se não bastasse, no mesmo minuto (BP, p. 47). Ao observar o chapéu de Bouvard, Pécuchet percebe que ambos tiveram a mesma ideia, de identificar os chapéus com o nome escrito no interior. Mais adiante, quando deixam Paris, graças à herança de Bouvard, durante o périplo em que se transforma a mudança, cheia de aventuras infelizes, Pécuchet, coincidentemente, encontra Bouvard (BP, p. 65). Esses acasos parecem expor o fato óbvio: não se trata de realidade, mas de uma construção, cujas regras atendem apenas e tão somente as necessidades da própria narrativa.

Essas "intervenções" do acaso sugerem uma oposição à ideia da narrativa como fluxo narrativo orgânico. Se, num primeiro momento, esses elementos surgem como uma quebra desse fluxo, por outro, colocam o problema da estruturação de blocos disjuntos, ou seja, da assimilação do fragmentário como discurso organizado. O problema que se coloca é explicitar exatamente a forma pela qual esse fragmentário adquire coesão, ou melhor, de que maneira percebemos um conjunto de fragmentos como texto.

Se o impasse é característico e evidente em BP, a impossibilidade da obtenção do conhecimento também ocupa parcela importante do texto. Bouvard, por exemplo, ignora que seu "tio" era, na verdade, seu pai biológico. Curiosamente, sua credulidade é quebrada exatamente no momento em que encara uma verdade: ao ser informado da herança deixada pelo pai, fica atônito e, apesar de todos os elementos que confirmam a autenticidade da mensagem, ainda duvida, pensando tratar-se de um golpe. Bouvard e Pécuchet, em sua sede insaciável de conhecimento, buscam não o conteúdo, mas o número, uma verdade insofismável:

${ }^{56}$ Do DIR. 
"À la grande bibliothèque ils auraient voulu connaître le nombre exact des volumes" (BP, p. 56). Em seu processo de educação, não aprendem, mas confundem-se e sonham:

Ils s'informaient des découvertes, lisaient les prospectus et par cette curiosité leur intelligence se développa. Au fond d'un horizon plus lointain chaque jour, ils apercevaient des choses à la fois confuses et merveilleuses.

En admirant un vieux meuble, ils regrettaient de n'avoir pas vécu à l'époque où il servait, bien qu'ils ignorassent absolument cette époque-là. D'après de certains noms, ils imaginaient des pays d'autant plus beaux qu'ils n'en pouvaient rien préciser. Les ouvrages dont les titres étaient pour eux inintelligibles leur semblaient contenir un mystère. (BP, p. 56-57)

O problema torna-se, então, saber como desfazer o véu que encobria esses mistérios. Mas tornar-se sábio não é fácil; seus sonhos e divagações cobram seu preço: "Et ayant plus d'idées, ils eurent plus de souffrances" (BP, p. 57). O lado prático da vida prescinde de finezas. Se os mapas são incapazes de informar (ou então: se ambos são incapazes de extrair informações dos mapas), não há problema. O que importa é que eles terão, efetivamente, uma casa ${ }^{57}$.

A certeza dos números, o sofrimento causado pela "elevação" do espírito para além das coisas práticas e essas necessidades indicam um desejo volátil por sinais exteriores, que reflitam uma condição desejada. Ter bons livros não é um objetivo em si: é preciso saber se eles merecem estar numa biblioteca:

II ne serait pas mal, non plus (car on ne peut pas toujours travailler dehors), d'avoir quelques bons ouvrages de littérature ; - et ils en cherchèrent, — fort embarrassés parfois de savoir si tel livre "était vraiment un livre de bibliothèque". Bouvard tranchait la question.

— "Eh ! nous n'aurons pas besoin de bibliothèque."

— "D'ailleurs, j'ai la mienne" disait Pécuchet. (BP, p. 61)

E a prática vence. Ao invés de refletir e estabelecer critérios, basta resignar-se aos critérios já aceitos, à biblioteca já formada, que não oferece desafios ao pensamento. A decisão é sempre difícil, os objetivos não têm um alvo definido, mas oscilam, pois o ideal é impreciso:

Ils voulaient une campagne qui fût bien la campagne, sans tenir précisément à un site pittoresque, mais un horizon borné les attristait. Ils fuyaient le voisinage des habitations et redoutaient pourtant la solitude. Quelquefois, ils se décidaient, puis craignant de se repentir plus tard, ils changeaient d'avis, l'endroit leur ayant paru malsain, ou exposé au vent de mer, ou trop près d'une manufacture ou d'un abord difficile. (BP, p. 62)

\footnotetext{
57 "Les cartes de géographie n'en disaient rien. Du reste, que leur maison fût dans tel endroit ou dans tel autre, l'important c'est qu'ils en auraient une". (BP, p. 60).
} 
Mas eles acreditam na superioridade do saber humano e na coisa mais bem partilhada no mundo : "Avec du bon sens et de l'étude ils s'en tireraient, sans aucun doute" (BP, p. 71). Sua busca, no entanto, é sempre desviada por indícios, que levam a descobertas inesperadas ${ }^{58}$, que nunca são apenas descobertas, mas pretextos para que o moto contínuo da narrativa prossiga. Chegando ao raciocínio aparentemente circular, embebido numa ironia calcinante: "Le verbe s'accorde toujours avec le sujet, sauf les occasions où le verbe ne s'accorde pas". (BP, p. 203)

Outro ponto relevante é a questão do progresso. A busca do saber empreendida por Bouvard e Pécuchet lembra a argumentação filosófica cartesiana, com sua lógica implacável. Ambos, porém, têm posições antagônicas a esse respeito:

Bouvard sees technology as essential to the progress in which he believes; Pécuchet couples his antiprogressive argument with a castigation of such technology: progress is impossible precisely because the machines which facilitate such forward motion encourage the development of diminished, mechanized humanity. (Rees, p. 272).

A construção lógica da superioridade do progresso engendra sua própria desmoralização. A tensão causada pela recurvação da noção sobre sua própria corrupção surge como outro aspecto da impossibilidade do conhecimento. Embora se mantenha o fluxo para diante do progresso técnico que triunfa, esse fluxo é fragmentado pelo impasse, pela necessidade da busca de alternativas que, eventualmente, levam ao mesmo ponto.

\footnotetext{
58 (...) Autant de problèmes, de points curieux à éclaircir.

Mais souvent un faible indice met sur la voie d'une découverte inappréciable. (BP, p. 156).
} 


\subsubsection{QUE SAIS-JE?}

No final do capítulo quatro, logo após terem decidido enfrentar não a literatura, mas os romances históricos, os dois copistas defrontam-se com seu expoente:

Ils lurent d'abord Walter Scott.

Ce fut comme la surprise d'un monde nouveau. (BP, p. 186)

Scott já aparecera em Madame Bovary. Sua leitura enleva os sonhos de Emma:

Avec Walter Scott, plus tard, elle s'éprit de choses historiques, rêva bahuts, salle des gardes et ménestrels. Elle aurait voulu vivre dans quelque vieux manoir, comme ces châtelaines au long corsage qui, sous le trèfle des ogives, passaient leurs jours, le coude sur la pierre et le menton dans la main, à regarder venir du fond de la campagne un cavalier à plume blanche qui galope sur un cheval noir (MB, p. 66)

Tanto num caso como em outro, a leitura de Scott parece produzir um efeito admirável, tanto que Bouvard e Pécuchet, “(...) en face l'un de l'autre, avec un livre à la main, (...) lisaient silencieusement." (BP, p. 186). O romance histórico surge como forma de restabelecimento ou "presentificação" da história, que se torna instrumento de fuga da realidade para Bovary, absorvendo intensamente. $E$ o efeito não parece gratuito, pois, como Henry James afirma, num ensaio de 1864, cerca de trinta anos após a morte de Scott:

Since Shakespeare, no writer had created so immense a gallery of portraits, nor, on the whole, had any portraits been so lifelike. Men and women, for almost the first time out of poetry, were presented in their habits as they lived. (James, 1987, p. 21)

No entanto, a dúvida como fator de impossibilidade surge, sutilmente: "Sans connaître les modèles, ils trouvaient ces peintures ressemblantes, et l'illusion était complète." (BP. p. 186). A sensação de realidade, decorrente da própria ignorância, participa na validação dessa realidade. Sem procurar responder à questão evidente (trata-se da visão de Flaubert, trata-se de ironia etc.), temos aspectos significantes nestas curtas passagens: a relação das personagens com a leitura e seu efeito e, de forma talvez mais profunda, a relação do texto com a tradição em que se insere, pois Walter Scott foi, em seu tempo, inventor de um novo estilo (James, 1987, p. 20). É 
lícito supor-se que a alusão, na forma como surge nos dois textos, além do "comentário" de um narrador não tão impassível sobre sua relação com a realidade, expresse um juízo de valor. Mas, levando em conta o próprio caráter ambíguo de uma afirmação (eles consideram as "pinturas" verossímeis) que carrega em si uma contradição (pois não conhecem os "modelos"59), e o próprio estatuto de um modelo de literatura já velho de meio século sugere algo mais que um julgamento esquemático.

A questão, embora externamente remeta à possibilidade de um padrão literário, num outro nível aponta para a possibilidade de um valor de verdade no universo ficcional, indo além do enunciado imanente e buscando-se 0 transcendente, e pensando na totalidade do texto de Bouvard e Pécuchet, pode-se questionar a ideia corrente na crítica de que este seria um "livro feito de livros". Não seria este um aspecto exterior da narrativa, que reclama uma leitura mais profunda, ou seja, indagar-se qual seria o papel dos livros no texto? Afinal, como vimos, os conhecimentos reproduzidos por Bouvard e Pécuchet surgem de fontes diversas, não apenas de livros, mas também de livros, sendo a manipulação que Flaubert faz desses conhecimentos o fator que, a nosso ver, sobressai e torna mais complexo o texto.

Segue-se na narrativa a leitura de outro autor conhecido por seus romances históricos: "Après Walter Scott, Alexandre Dumas les divertit à la manière d'une lanterne magique". (BP, p. 187). O efeito da leitura é similar àquele causado por um aparato que projeta imagens e que diverte. No divertimento, como em Dumas, "(...) tout se mêle, court et se débrouille, sans une minute pour la réflexion". (BP, p. 187). Se Emma, Bouvard e Pécuchet são enlevados pela leitura e nela tornam-se nefelibatas $^{60}$, esse efeito é obtido pela falta de reflexão; entretanto, como pensar, pois, como afirmado acima, os modelos - em suma, a realidade - não são conhecidos?

Passando a outra questão suscitada, graças às leituras, o gosto dos copistas modifica-se, tornando-os mais exigentes: "(...) ils ne purent tolérer le fatras de Bélisaire, la niaiserie de Numa Pompilius, Marchangy ni d’Arlincourt." (BP, p. 187). Neste trecho curto temos um exemplo de recurso empregado à exaustão, a

\footnotetext{
${ }^{59}$ A metáfora pictórica é repetida diversas vezes nessa passagem.

${ }^{60} \mathrm{O}$ preciosismo vocabular é justificado, pois assim se designa o escritor que não segue regras e também aquele que foge da realidade.
} 
enumeração. Lembrando a citação anterior, a sucessão de nomes sugere a aglutinação que impede a reflexão. Um leitor dotado de amplo conhecimento talvez até possuísse condições de avaliar a importância relativa das citações e de, contrapondo-as às leituras de Scott e Dumas, emitir um julgamento abalizado. Mas seria útil buscar no acúmulo de conhecimento, mesmo acompanhado da reflexão, essa resposta? Ela não será encontrada, em seu lugar surge a complicação, mais adiante, numa citação um pouco longa, que enfoca os elementos citados nos parágrafos acima:

Pécuchet consultait la biographie universelle - et il entreprit de réviser Dumas au point de vue de la science.

L'auteur, dans Les Deux Diane se trompe de dates. Le mariage du Dauphin François eut lieu le 14 octobre 1548, et non le 20 mars 1549. Comment sait-il (voir Le Page du Duc de Savoie) que Catherine de Médicis, après la mort de son époux voulait recommencer la guerre ? II est peu probable qu'on ait couronné le duc d'Anjou, la nuit, dans une église, épisode qui agrémente La Dame de Montsoreau. La Reine Margot, principalement, fourmille d'erreurs. Le duc de Nevers n'était pas absent. II opina au conseil avant la Saint-Barthélémy. Et Henri de Navarre ne suivit pas la procession quatre jours après. Et Henri III ne revint pas de Pologne aussi vite. D'ailleurs, combien de rengaines, le miracle de l'aubépine, le balcon de Charles IX, les gants empoisonnés de Jeanne d'Albret. Pécuchet n'eut plus confiance en Dumas.

II perdit même tout respect pour Walter Scott, à cause des bévues de son Quentin Durward. Le meurtre de l'évêque de Liège est avancé de quinze ans. La femme de Robert de Lamarck était Jeanne d'Arschel et non Hameline de Croy. Loin d'être tué par un soldat, il fut mis à mort par Maximilien, et la figure du Téméraire, quand on trouva son cadavre, n'exprimait aucune menace, puisque les loups l'avaient à demi dévorée.

Bouvard n'en continua pas moins Walter Scott, mais finit par s'ennuyer de la répétition des mêmes effets. L'héroïne, ordinairement, vit à la campagne avec son père, et l'amoureux, un enfant volé, est rétabli dans ses droits et triomphe de ses rivaux. II y a toujours un mendiant philosophe, un châtelain bourru, des jeunes filles pures, des valets facétieux et d'interminables dialogues, une pruderie bête, manque complet de profondeur. (BP, p. 188-189).

Desconhecer os fatos permitia que tanto Bouvard como Pécuchet admirassem sua beleza. Entretanto, a análise mais profunda solapa seu fundamento. Os "erros" históricos - que outro leitor poderia considerar "liberdades poéticas" - tornam-se desabonadores. A sucessão de incorreções, apresentadas no mesmo ritmo frenético que impede a reflexão, parece ter como objetivo distanciar o leitor do raciocínio, como se fossem listas de termos disparatados, cujo único aspecto em comum seria a própria presença na lista. Entretanto, a destruição da impressão de verossimilhança causada inicialmente é empreendida pela leitura de outro livro, a Biographie Universelle, este também uma forma de lista, em ordem alfabética, com 85 volumes. (BP, p. 188n). Qual a fonte de autoridade da Biographie? O fato de se tratar de obra de referência? Como saber se esses dados, que se opõem à criação literária, efetivamente são dignos de confiança? Chega-se a novo impasse: a 
primeira impressão sobre os textos lidos pelos copistas (ou o primeiro contato sensível com esses textos) não é suficiente, a leitura informada não apenas destrói a confiança nos textos, como não os substitui por outros textos (ou seja, não mostra os textos "corretos"). Além disso, a percepção do mecanismo (a repetição de efeitos) torna-se também desabonadora. A solução ao impasse é simples: prosseguir sempre. Bouvard descobre, num salto, George Sand. Não há qualquer justificativa (por que exatamente George Sand?), Bouvard apenas procede "En haine du bric-àbrac" (BP, p. 189). Ele foge das coisas disparatadas, embora a possibilidade de identificá-las seja pequena.

A convenção dramática será a próxima vítima dessa destruição do saber. Há, no entanto, uma predisposição à crítica na visão de Bouvard dos dramaturgos:

(...) enfin, tous les caractères se montrent d'un seul bloc, par amour des idées simples et respect de l'ignorance - si bien que le dramaturge, loin d'élever abaisse, au lieu d'instruire abrutit. (BP, p. 190)

Aqui, encontramos um tipo de preceito que lembra as poéticas clássicas. A função do dramaturgo seria elevar (tornar sublime?) e instruir. No entanto - e, novamente, há um choque entre o idealismo e a realidade -, esta sempre nega aquele. As prescrições continuam, na medida em que as leituras são feitas:

Ils reprochaient à tous ceux-là de ne rien dire sur le milieu, l'époque, le costume des personnages. Le cœur seul est traité ; toujours du sentiment ! comme si le monde ne contenait pas autre chose! (BP, p. 190).

Parece emanar do texto uma poética do real. A verdade histórica, a recusa às convenções, a elevação e o sublime, o retrato social. Mais adiante, é a interpolação de informações fúteis, que "d'abord les charma, puis leur parut stupide; - car l'auteur efface son œuvre en y étalant sa personne." (BP, p. 190). Temos, assim, mais um aspecto dessa pequena poética: a ausência do autor de seu texto. Ora, é bastante conhecida a posição de Flaubert a esse respeito; seria excessivamente simples afirmar que os valores literários (ou melhor, os valores preconizados no texto) coincidem com aqueles defendidos por seu autor. É uma questão que não será respondida aqui, pois será mantido o foco no texto.

A "pequena poética bouvardiana" prossegue. Desta vez, é a relação entre o realismo de Balzac e sua interpretação do real. 
L'œuvre de Balzac les émerveilla, tout à la fois comme une Babylone, et comme des grains de poussière sous le microscope. Dans les choses les plus banales, des aspects nouveaux surgirent. Ils n'avaient pas soupçonné la vie moderne aussi profonde.

_ "Quel observateur !" s'écriait Bouvard.

- "Moi je le trouve chimérique" finit par dire Pécuchet. "Il croit aux sciences occultes, à la monarchie, à la noblesse, est ébloui par les coquins, vous remue les millions comme des centimes, et ses bourgeois ne sont pas des bourgeois, mais des colosses. Pourquoi gonfler ce qui est plat, et décrire tant de sottises ? II a fait un roman sur la chimie, un autre sur la Banque, un autre sur les machines à imprimer. Comme un certain Ricard avait fait "le cocher de fiacre", "le porteur d'eau", "le marchand de coco". Nous en aurons sur tous les métiers et sur toutes les provinces, puis sur toutes les villes et les étages de chaque maison et chaque individu, ce qui ne sera plus de la littérature, mais de la statistique ou de l'ethnographie." (BP, p. 191)

O mesmo percurso é repetido: inicialmente, Bouvard e Pécuchet admiram-se com a profundidade da vida moderna, exatamente como ficaram impressionados com o romance histórico de Scott, para, em seguida, perceberem inconsistências em relação a um ideal de literatura, que lembra a crítica formulada por Turguêniev ao projeto da "enciclopédia crítica em farsa". Há, no entanto, uma contradição em relação aos preceitos formulados anteriormente: se antes era necessário "elevar", aqui não se deve inchar o que é plano. Descrever aspectos desimportantes também deve ser evitado, e a importância dada à descrição parece ganhar importância.

Deste ponto em diante, a "poética" passa a observar aspectos menos gerais, mais ligados ao emprego literário da língua. A ênfase da tragédia (BP, p. 192) cede lugar à comédia e à tentativa frustrada de Pécuchet em Molière:

Ils abordèrent la Comédie - qui est l'école des nuances. II faut disloquer la phrase, souligner les mots, peser les syllabes. Pécuchet n'en put venir à bout - et échoua complètement dans Célimène. (BP, p. 193)

Passou-se da leitura silenciosa de Scott à declamação teatral. O corpo passa a ser o veículo da expressão, mas é necessário saber como fazê-lo. De forma surpreendente, passa-se da reflexão literária para a esfera da arte e sua capacidade de mover o ser humano, mas não qualquer humano:

D'abord, ils marchèrent le long des quenouilles, sans parler. II était encore ému de sa déclamation ; - et elle éprouvait au fond de l'âme comme une surprise, un charme qui venait de la Littérature. L'Art, en de certaines occasions, ébranle les esprits médiocres ; - et des mondes peuvent être révélés par ses interprètes les plus lourds. (BP, p. 197-198) 
Da mesma forma que passam de um gênero a outro e de um período a outro, os dois decidem exercitar sua criatividade.

Enfin, ils résolurent de composer une pièce.

Le difficile c'était le sujet.

Ils le cherchaient en déjeunant, et buvaient du café, liqueur indispensable au cerveau, puis deux ou trois petits verres. Ensuite, ils allaient dormir sur leur lit ; après quoi, ils descendaient dans le verger, s'y promenaient, enfin sortaient pour trouver dehors l'inspiration, cheminaient côte à côte, et rentraient exténués. (BP, p. 199)

A decisão é simples. Efetivamente proceder à criação apresenta-se como um impasse desde a seleção de um assunto. O que se resolve com método. Mas os inúmeros métodos também são insuficientes:

Mais il existe des méthodes pour découvrir des sujets. On prend un titre, au hasard, et un fait en découle ; on développe un proverbe, on combine des aventures en une seule. Pas un de ces moyens n'aboutit. Ils feuilletèrent vainement des recueils d'anecdotes, plusieurs volumes des causes célèbres, un tas d'histoires. (BP, p. 200).

Chega-se a mais um impasse, marcado pela aporia:

Donc les règles ne suffisent pas. Il faut, de plus, le génie.

Et le génie ne suffit pas. (BP, p. 201)

Seria possível ver aqui o fechamento de um círculo. Após estabelecer uma série de regras a respeito de um ideal de literatura, chega-se à constatação de que as regras não são suficientes. Mas podemos também notar o movimento que vai da leitura à prática, desembocando no uso do próprio corpo. Sendo assim, a busca de saberes cede espaço à sua inábil aplicação e é nessa aplicação pouco sútil que surgem os impasses. Embora fruto de longa acumulação de leituras e de pesquisas, parece-nos, como já afirmamos, que o trabalho de Flaubert concentra-se na elaboração e manipulação desses saberes, atendendo a um projeto estético, o que justificaria os processos empregados no tratamento da proto-enciclopédia. 


\subsubsection{PRESENTE/SILÊNCIO/REPETIÇÃO}

Mary Rice (1990) analisa o que vê como o fracasso da metáfora como um paradigma histórico. Partindo da análise da relação entre Salammbô e o fundo histórico das revoluções democráticas que ocorreram na França no século 19, e que mantiveram os privilégios da burguesia, Rice afirma que

Salammbô is $(\ldots)$ grounded in resemblance to the present rather than any causal relationship with it, and as history, the novel is informed by metaphor (...). The two elements of metaphor therefore exist in the tension between their difference and their resemblance. (Rice, 1990, p. 96).

Em outras palavras, é a semelhança com os eventos de 1830, 1848 e 1871 e não uma eventual relação causal (um realismo?) com a Paris moderna do século 19, época do progresso técnico e científico considerado inesgotável, que serve como base para o romance histórico de Flaubert, que por outro lado, deve ser, "at some level (...) profoundly ahistorical, asserting the sameness of all historical periods" (Rice, 1990, p. 98). A autora encerra sua análise afirmando que

(...) a metaphoric vision of history, especially one in which metaphors tend to collapse into simple identity, suggests that the ultimate result of difference and change is stasis, an immobility much like that of so much of Flaubert's plastic imagery. Certainly, this metaphoric perspective can be disturbingly pessimistic, denying all hope for progress. History is always "à refaire" (...). It is not only to be rewritten, but also to be repeated in the form of events, relived over and over again. Even so, Flaubert's metaphoric history offers us a rich insight into the past and perhaps the present. (Rice, 1990, p. 98).

Bouvard e Pécuchet apresenta uma relação que não se dá em termos de passado e presente, mas no próprio presente e em sua relação com a história, embora também permita uma visão que o leitor pode relacionar com (seu) passado e (seu) presente. A busca desenfreada por "conhecimentos" empreendida pelos dois copistas encontra paralelo na crença no progresso científico ilimitado. Como descreve Hobsbawm, a sociedade burguesa do final do século 19 encontrava-se "confiante e orgulhosa de seus sucessos" (Hobsbawm, 2007, p. 349), em razão do grande progresso técnico e científico que, na visão burguesa, levaria à supremacia da ciência sobre todas as outras formas de atividade intelectual. Os próprios cientistas não hesitavam em erigir teses "definitivas", haja vista terem logrado atingir 
os "limites" da ciência, o que obviamente era mais uma bêtise. Enquanto a realidade avassaladora não encontrava limites aos seus voos imaginários - e que conduziriam à longa guerra mundial -, temos no romance uma sucessão de fracassos (as palavras de Beckett em Worstward Ho ecoam: "Ever tried. Ever failed. No matter. Try again. Fail again. Fail better."). Bouvard e Pécuchet, embora hesitem ocasionalmente, parecem buscar o mundo pela palavra. $E$ falham seguidamente em seu percurso; ao saltitar de um ramo do conhecimento ao outro, ambos extraem as contradições fundamentais entre fontes e buscam ("clicam" em) novas fontes para superar essas contradições. O paralelo com o labirinto parece claro. Escolhe-se um caminho, entre opções similares (não-hierarquizadas), chega-se a um beco; a partir daí, volta-se sobre os próprios passos e, eventualmente, consegue-se ir além - não necessariamente para frente. E surge um novo impasse, que pode situar-se tanto na própria busca do conhecimento quanto na indefinição quanto à atitude a tomar.

A consciência do fracasso das próprias escolhas leva neste caso não à ação, mas ao silêncio. O problema surge pela impossibilidade de discernir alternativas viáveis. Nas coleções de minerais e de obras da técnica exibidas nas Exposições Universais, a mesma sensação: qual o objetivo de tanto progresso? Qual o "conhecimento" gerado, se não a exaltação do gênio humano? Se a palavra é a um só tempo incapaz de digerir a realidade e é necessária para, ao menos, conhecê-la, qual o caminho? Voltar à sua catalogação (voltar a copiar), resignadamente?

A realidade da segunda metade do século 19 apresenta-se sem pudores, no momento em que Haussmann assombra o sono de Pécuchet. A grande reforma de Paris realizada pelo Barão mudou a face da cidade e foi descrita também por Zola, de forma impressionante:

Là-bas, du côté des Halles, on a coupé Paris em quatre. Oui, la grande croisée de Paris, comme ils disent. Ils se dégagent le Louvre et l'Hôtel de Ville. Quand le premier réseau sera fini, alors commencera la grande danse, le second réseau trouera la ville de toutes parts pour rattacher les faubourgs au premier réseau. Les tronçons agoniseront dans le plâtre... Une entaille là, une entaille plus loin, des entailles partout. Paris haché à coups de sabre, les veines ouvertes. (Zola, 1970, p.97).

A nova paisagem de Paris, com suas linhas retas, grandes áreas abertas que servem de moldura para inúmeros monumentos, inserem-se numa tradição do embelezamento. Edifícios semelhantes, que ornam bulevares, aberturas que incomodam o olho do artista e que lembram quartéis permitem, em compensação, 
caminhar seguramente, "les mains dans les poches, sans nous égarer" (Des Cars, 1991, p. 181). A intervenção niveladora ocorre também no sentido próprio, elevações são aplainadas e o "décorateur émérite" que é Haussmann consegue consertar os estragos feitos pelo tempo, o crescimento explosivo enquadrado pelo desenho medieval sempiterno. Esta Paris antiga permanece nos bastidores de um capitalismo triunfante e excludente. "Sous le Paris actuel, l'ancien Paris est distinct, comme le vieux texte dans les interlignes du nouveau" (Des Cars, 1991, p. 182). Atrás do cenário resplandescente, traços de um passado teimoso, onde a rua de Haussmann é "une discontinuité momentanée de la ville ancienne". Em outras palavras, a alegada monotonia da nova Paris é ilusória. "L’inégalité (urbanística, arquitetônica e social, a meu ver) est là, dans la dissymétrie des interventions" (Des Cars, 1991, p. 182). O novo e o antigo revelam-se um ao outro, numa cidade-monumento.

Enquanto isso, em Chavignoles, os grandes trabalhos são apenas um capricho do copista, que precisa seguir sempre, buscando um caminho entre as alternativas possíveis e não as encontrando. A velha Paris morre de certa forma sob a pá de Haussmann, a "nova" Chavignoles de Pécuchet é apenas um vínculo a mais numa odisseia estática, plena de descontinuidades. A escrita de Flaubert revolve num espelhamento imperfeito realidade e ficção ${ }^{61}$, visando reproduzir pelo trabalho da escrita, efeito diverso, com o objetivo de desafiar a ficção:

(...) for the task he had set for himself was nothing less than to achieve by labor effects comparable to those of appalling incompetence: the incompetence that supposes the mirror held up to nature when two lay figures seat themselves simultaneously and take off in synchrony their hats: the incompetence, in short, of fiction itself, which is endlessly arranging things. He will use fiction itself to vanquish fiction; he vill arrange, and maneuver, and contrive, to such bland effect that no one will ever afterward be quite sure where contrivance began and serendipity left off. He will use with cunning every device of the merely facile novelist; and the result will be such a compendium of unreality that it will seen real. (Kenner, 2005, p. 12).

O limite entre a maquinação e o achado feliz, a proliferação de técnicas visando um nivelamento das ideias levam à relação entre obra e realidade, mediada ainda pela visão de Flaubert do trabalho do escritor, como de Biasi coloca:

Une lettre à G. Sand de décembre 1875 conduit à considérer avec prudence la notion de "réalisme documentaire" communément admise pour parler du travail de l'écrivain. Outre les distances que Flaubert y prend à l'égard du "réalisme" et du "naturalisme" comme "écoles", on voit s'y affirmer, en accord avec ce que démontrent concrètement les carnets, un certain désaveu de l'exigence référentielle, et tout au moins, une conception très désinvolte du

\footnotetext{
${ }^{61}$ Referimo-nos aqui à questão da relação de Flaubert com o "realismo", e não a uma relação direta.
} 
maniement des sources. S'il s'agit encore de réalisme, il faudrait parler d'un "réalisme ludique" et si le document y joue un rôle non négligeable (ce que je crois) c'est avec cette particularité d'être assujetti presque a priori aux réquisits du style (...) Enfin, je tâche de bien penser pour bien écrire. Mais c'est bien écrire qui est mon but, je ne le cache pas.

Dans un tel contexte, "bien penser" prend visiblement, pour Flaubert, une triple signification : une valeur épistémique (penser avec exactitude, utiliser sa faculté de penser avec rigueur), une valeur programmatique (anticiper efficacement sur l'avenir du travail, se doter d'éléments utiles à l'œuvre future) et une valeur éthique (penser selon l'ordre du bien, se construire une morale provisoire conforme aux exigences de l'œuvre). (De Biasi, 1995).

Ou seja, apesar do rigor documental - e das diversas anedotas que circulam a esse respeito -, o trabalho de Flaubert é a escrita, não a catalogação pura e simples, e submetida a princípios rígidos. As reflexões e refrações da realidade que encontramos em Bouvard e Pécuchet atendem, em primeiro lugar, às necessidades estéticas e técnicas do escritor, embora, e esse seria um ponto de discussão, um suposto "realismo lúdico" em Flaubert devesse estar submetido aos significados do bien penser, esse realismo, diferentemente do proposto por Adorno ${ }^{62}$ (2003, p. 60), leva o leitor para o centro do palco e, ao mesmo tempo em que conduz, na medida em que escolhe seu caminho interpretativo, esse leitor é conduzido, pela construção engenhosa do urso de Croiset, encarando a si no espelho que nos mostram Bouvard e Pécuchet.

62 "O romance tradicional, cuja ideia talvez se encarne de modo mais autêntico em Flaubert, deve ser comparado ao palco italiano do teatro burguês", afirma Adorno. 


\subsubsection{ILUSÃO CÔMICA: BÊTISE E REPETIÇÃO}

"Il y a quelque chose dans ce spectacle, répondit le consciencieux, et il mit le doit à son nez, il y a quelque chose dans ce spectacle qui fait même du bien à ma conscience."

Nietzsche

Deleuze sugere a possibilidade do conhecimento por meio da bêtise. Nesse ponto, é possível discutir um possível esquema argumentativo e sua relação com o "percurso" do texto. Será questionada a pertinência da observação sobre o "projeto" de Flaubert:

Como foi reconhecido de diversas maneiras por tantos autores (Flaubert ou Lewis Carrol), o mecanismo do não-senso é a mais elevada finalidade do sentido, assim como o mecanismo da besteira é a mais elevada finalidade do pensamento. (DELEUZE, 2006, p. 223).

Retomando a análise de Dord-Crouslé, a pesquisadora afirma que

A originalidade do projeto de Flaubert não é, portanto, inscrever seu projeto em uma ficção (outros o haviam inscrito), mas conjugar a opção enciclopédica com a questão da tolice, fundamental, aliás, em toda a sua obra. (BP, p. 23).

Temos aqui outro aspecto caro aos críticos, a bêtise, ligado à catalogação universal (e, portanto, enciclopédica ${ }^{63}$ ). Deleuze, em Diferença e Repetição, fala a esse respeito:

A pior literatura faz coleções de tolices; mas a melhor foi obcecada pelo problema da besteira, problema que ela soube conduzir até as portas da Filosofia, dando-lhe sua dimensão cósmica, enciclopédica e gnoseológica (Flaubert, Baudelaire, Bloy). (Deleuze, 2006, p. 218).

O aspecto filosófico levantado por Maupassant ganha relevo. A besteira como obsessão. Seja como repertório de disparates, tendo como resultado uma literatura menor, seja como, e esse é o ponto que nos interessa, teoria geral do conhecimento humano, com caráter enciclopédico e desaguando em "clássicos" literários. Essa seria uma forma de reflexão sobre o conhecimento e sua natureza, fazendo surgir do choque entre sentido e não-sentido uma transcendência:

63 “Enkýklios", "paideía”, etimologicamente significam “instrução circular ou geral”. 
A besteira não é o fundo, nem o indivíduo, mas a relação em que a individuação eleva o fundo sem poder dar-lhe forma (...). Todas as determinações se tornam cruéis e más, sendo apreendidas tão-somente por um pensamento que as contempla e as inventa, esfoladas, separadas de sua forma viva, flutuando sobre esse fundo morno. Tudo se torna violência sobre este fundo passivo, ataque sobre esse fundo digestivo. Aí se opera o sabá da besteira e da maldade. Talvez seja esta a origem da melancolia que pesa sobre as mais belas figuras do homem: o pressentimento de uma hediondez própria do rosto humano, de uma irrupção da besteira, de uma deformação no mal, de uma reflexão na loucura. Com efeito, do ponto de vista da Filosofia da natureza, a loucura surge no ponto em que o indivíduo se reflete neste fundo livre e, por conseguinte, a estupidez na estupidez, a crueldade na crueldade e assim por diante, até não poder mais suportar-se. "Então, uma faculdade lamentável se desenvolve em seu espírito, a de ver a besteira e não mais tolerá-la...". É verdade que esta faculdade mais lamentável torna-se também a faculdade régia quando ela anima a Filosofia como Filosofia do espírito, isto é, quando induz todas as outras faculdades a este exercício transcendente que torna possível uma violenta reconciliação do indivíduo, do fundo e do pensamento. Então, os fatores de individuação intensiva tomam a si próprios como objetos, de maneira a constituírem o elemento mais elevado de uma sensibilidade transcendente, o sentiendum; e, de faculdade em faculdade, o fundo é levado ao pensamento, sempre como não-pensado e não-pensante, mas este não-pensado se tornou a forma empírica necessária sob a qual o pensamento, no Eu rachado (Bouvard e Pécuchet), pensa, enfim, o cogitandum, isto é, o elemento transcendente que só pode ser pensado ("o fato de que nós não pensamos ainda" ou O que é besteira?). (Deleuze, 2006, p. 219-220).

Os extremos parecem unir-se. O sentido visto como finalidade última do nãosenso, enquanto o mecanismo da besteira é visto como finalidade última do pensamento, num jogo que constitui para Deleuze o cerne da "viagem" ${ }^{64}$ de Bouvard e Pécuchet (Deleuze, 2006, p. 223). Além disso, a besteira desvela, a um só tempo, a impotência do pensar e a força que impele esse mesmo pensar (idem, p. 381). Essa tensão e suas implicações filosóficas levam à consideração do texto de Flaubert como investigação, que se realiza no ato da leitura, dos aspectos amplos e fundamentais do ser. A bêtise assume o papel de gatilho de reflexões-ecos na relação do ser com o texto e consigo mesmo. Apenas, para Flaubert, "(...) la bêtise est une force positive et le sot devient un oppresseur." (Sartre, 1971, p. 613)

Não é o caso de perguntar se Bouvard e Pécuchet são bestas ou não. Esta não é a questão. O projeto de Flaubert é enciclopédico e "crítico", não psicológico ${ }^{65}$. O problema da besteira é colocado de maneira filosófica, como problema transcendental das relações entre a besteira e o pensamento. No mesmo ser pensante desdobrado ou, antes, repetido, trata-se da besteira como faculdade e, ao mesmo tempo, da faculdade de não suportar a besteira. Flaubert, aqui, reconhece Schopenhauer como seu mestre. (Deleuze, 2006, p. 381n).

O aspecto gnoseológico do enciclopedismo bête proposto por Deleuze, confrontado com as leituras que propõem a circularidade estrutural, sugere uma tensão incontornável. Supondo-se a besteira instrumento de conhecimento, o

\footnotetext{
64 “Le voyage de Mercier et Camier, je peux le raconter si je veux, car j'étais avec eux tout le temps".

${ }^{65} \mathrm{O}$ que vai de encontro à afirmação de Dord-Crouslet citada anteriormente.
} 
retorno contínuo torna-se obsoleto, mesmo que a única diferença entre os extremos seja apenas a incapacidade em tolerá-la. Uma última afirmação de Dord-Crouslet, no entanto - e levando-se em conta nossa discordância de sua visão de estrutura "em espiral" - forma a base de nossas indagações a respeito de Bouvard e Pécuchet.

Retomando a citação sobre a circularidade do romance de Flaubert (p. 47 acima), num primeiro momento, gostaria de contrapor a impossibilidade de uma conclusão à impossibilidade de uma decisão. Enquanto a primeira sugere a ausência de um ponto final, de um desfecho, a segunda aponta a situação em que tomar uma decisão é inexequível ${ }^{66}$. Um segundo passo consistiria em problematizar a ficção como espaço de resolução de problemas. Finalmente, a fórmula "montagem significativa" sugere procedimentos que seriam introduzidos na arte ao longo do século 20, como a colagem, a montagem e a justaposição, que também remetem, simultaneamente, ao enfraquecimento da posição do espectador, ao romper expectativas sobre aspectos fundamentais da obra de arte, mas também colocam em proeminência o mesmo espectador como instância privilegiada da produção de sentido. Estes aspectos possibilitariam realizar, em nosso entendimento, a junção de aspectos macro e microtextuais na análise de Bouvard e Pécuchet ${ }^{67}$.

Vimos anteriormente que a repetição da mesma situação contribuiria para 0 aspecto dito cômico de BP. É conhecido o efeito da repetição, por exemplo, no teatro. São repetidas palavras, situações ou gestos, de forma a causar o riso pelo artificialismo forçado da reiteração. No entanto, a repetição pode ser vista também como elemento estrutural, pois, juntamente com o contraste, ela serve de fator de unidade, o que pode ser visto de forma mais evidente na música, por exemplo, pelo desenvolvimento de motivos musicais.

Um motivo é um grupo de notas ou figuras rítmicas que serve como núcleo gerador de uma melodia, constituindo sua menor unidade coerente. Ao iniciar uma melodia com um motivo, um compositor pode desenvolvê-la de várias formas, seja por meio de sua repetição inalterada ou pela repetição modificada (por exemplo, pela mudança de ritmo, ou pela substituição de uma ou duas notas). Pode, ainda,

\footnotetext{
66 "I can't go on. I must go on"

${ }^{67}$ É óbvia a tentação de estabelecer uma poética flaubertiana; tarefa espinhosa, pois pressupõe coerência e a possibilidade da redução de elementos díspares, por meio de termos como "estilo", "projeto" e assim por diante. A contribuição deste trabalho encontra-se exatamente na explicitação dessas configurações em um texto específico.
} 
transpor o motivo para uma altura mais alta ou mais baixa (mais agudo ou grave), modificar-lhe o rítmo ou a tonalidade.

Pode-se, ainda, adicionar um ou mais motivos ao primeiro motivo. Por meio da repetição - e cabe ressaltar que, como veremos, não se trata da repetição pura e simples, já que pode haver um tratamento diferenciado delas -, pode-se tanto obter a unidade da peça musical, como a variedade, haja vista que a adição de novos motivos cria o contraste.

Temos, assim, diversos aspectos que tornam mais complexa a análise da repetição: recurso cômico, dispositivo de unidade e variedade. Claramente, a repetição pode, voltando ao âmbito literário, assumir tambés essas configurações. Nesse ponto, observemos a constatação de Deleuze a respeito da repetição, quando "o obsessivo repete um cerimonial (...)" (Deleuze, 2006, p. 399):

\footnotetext{
Repete-se duas vezes simultaneamente, mas não se trata da mesma repetição: repete-se uma vez mecânica e materialmente, em comprimento, a outra vez simbolicamente, por simulacro, em profundidade; uma vez repetem-se partes, uma outra vez repete-se o todo do qual as partes dependem. Essas duas repetições não se fazem na mesma dimensão, mas coexistem; uma é repetição dos instantes, outra é repetição do passado; uma é elementar e a outra é totalizante. A mais profunda, a "produtora", evidentemente não é a mais visível ou a que faz mais "efeito". Em geral, as duas repetições entram em tantas relações diferentes que seria preciso um estudo clínico bastante sistemático, ainda não realizado, para distinguir os casos que correspondem as suas combinações possíveis. (Deleuze, 2006, p. 400)
}

Apropriando-se das considerações do filósofo francês, e retomando nosso paralelo com a música, mesmo a repetição exata de um motivo pode ser considerada uma repetição "diferencial": somos apresentados a determinado material, revestido de novidade e, ao sermos confrontados novamente com o mesmo material, geramos relações inumeráveis entre essas aparições desses elementos, da mesma forma que, no labirinto, ao escolher um caminho, criamos possibilidades, antecipações e conjecturas em torno não só do caminho a seguir, mas do percurso já realizado. Nesse sentido, a repetição seria "a potência da linguagem, e, em vez de se explicar de maneira negativa, por uma insuficiência dos conceitos nominais, ela implica uma Idéia da poesia sempre excessiva." (Deleuze, 2006, p. 401) Embora seja possível elaborar-se de forma detalhada um "modelo" do procedimento de aquisição de saber por parte de Bouvard e Pécuchet, sua falta de discernimento (bêtise) e a repetição incessante da mesma situação desempenham papel central na desestabilização das expectativas do leitor, enredado na impossibilidade de decidir se está de um lado ou de outro do espelho. Ironicamente (como sempre), pode-se 
dizer que não há decisão possível, pois ele encontra-se a um só tempo em ambos os lados.

Repetição e bêtise seriam, assim, aspectos complementares, que encarnam um desejo de transcendência pelo riso, que seria, para Flaubert, "(...) le dédain et la compréhension mêlés, et en somme la plus haute manière de voir la vie." (Para Louise Colet, 2/03/1854). Repetição e bêtise atuam simultaneamente, "disfarçadas". O artificialismo da repetição é espelhado pelo artificialismo do cômico absurdo que acompanha as repetições do mesmo procedimento; este, no entanto, adquire um caráter de diferenciação na repetição, relacionando-se, ainda, com a cópia, atividade menor, por um lado, mas origem da capacidade criadora, por outro. É nessa relação entre repetição, diferença e cômico que ressurge o aspecto trágico do texto, ecoado por Giles Deleuze, que liga o aspecto da repetição à mecanização da vida moderna, subordinada ao modo de produção industrial:

Talvez o mais elevado objeto da arte seja fazer que todas essas repetições atuem simultaneamente, com sua diferença de natureza e de ritmo, seu deslocamento e seu disfarce respectivos, sua divergência e seu descentramento, encaixá-las umas nas outras e de uma à outra, envolvê-las em ilusões cujo "efeito" varia em cada caso. A arte não imita, mas isso acontece, antes de tudo, porque ela repete, e repete todas as repetições, a partir de uma potência interior (a imitação é uma cópia, mas a arte é simulacro, ela subverte as cópias em simulacros). Até mesmo a repetição mais mecânica, mais cotidiana, mais habitual, mais estereotipada encontra seu lugar na obra de arte, estando sempre deslocada em relação a outras repetições com a condição de que se saiba extrair dela uma diferença para estas outras repetições. Isto porque não há outro problema estético a não ser o da inserção da arte na vida cotidiana. Quanto mais nossa vida cotidiana aparece estandardizada, estereotipada, submetida a uma reprodução acelerada de objetos de consumo, mais deve a arte ligar-se a ela e dela arrancar esta pequena diferença que, por outro lado e simultaneamente, atua entre outros níveis de repetição, como também fazer os dois extremos das séries habituais de consumo ressoares com as séries dos instintos de destruição e de morte; juntando assim o quadro da crueldade ao da besteira [...] (Deleuze, 2006, p. 403-404)

A crueldade trágica, dissimulada por trás da repetição e da bêtise, ligada à busca incessante do saber e à crença no progresso ilimitado parecem constituir o cerne da narrativa, que, além disso, se caracteriza pela insolubilidade da tensão entre saber e ignorância, pois é nela que bêtise e razão podem levar ao conhecimento, não um conhecimento positivo, mas aquele que se despe das crenças aceitas e busca um novo conhecimento. Esse mecanismo é considerado por Deleuze a grande força de Bouvard e Pécuchet:

A besteira (e não o erro) constitui a maior impotência do pensamento, mas também a fonte de seu mais elevado poder naquilo que o força a pensar. Esta é a prodigiosa aventura de Bouvard e Pécuchet, ou o jogo do não senso e do sentido. Deste modo, o indeterminado e a determinação permanecem iguais sem avançar, um sempre adequado ao outro. Estranha 
repetição que os reconduz à máquina de fiar ou, antes, à mesma dupla escrivaninha. Chestov via em Dostoievski o resultado, isto é, o acabamento e a saída da Crítica da razão pura. Que nos seja por um momento permitido ver em Bouvard e Pécuchet o resultado do Discurso do método. O cogito é uma besteira? É necessariamente um não-senso, na medida em que essa proposição pretende dizer ela própria o seu sentido. Mas é também um contra-senso (e isto Kant o mostrava), na medida em que a determinação Eu penso pretende incidir imediatamente sobre a existência indeterminada existo, sem assinalar a forma sob a qual o indeterminado é determinável. (Deleuze, 2006, p. 381-2)

Não sugerimos aqui a ficção como espaço de resolução de problemas. No entanto, Popper (2006), ao analisar o conhecimento científico, tece considerações sobre o duplo jogo de conjecturas e refutações que levam a ele. Para este filósofo, são as interações entre os dois fatores citados que levam ao conhecimento dito científico, que não se baseia no método indutivo (ou seja, que parte do particular concreto para chegar ao geral abstrato). Numa nova versão do labirinto, o cientista formula teorias (escolhe caminhos), que serão testadas e corrigidas ou refutadas, servindo de base para novas teorias (novos caminhos). Assim, o conhecimento seria "fundamentalmente conjectural", progredindo "por ensaio e erro". (Popper, 2006, p. ii)

Nesse ponto, podemos relacionar essa lógica da busca do conhecimento com a "lógica" do conhecimento de Bouvard e Pécuchet. Ambos erram repetidamente - e aqui não nos importa a razão desse fato, apenas que eles parecem não aprender com esses erros. No entanto, o cientista encontra-se em situação semelhante, pelo simples motivo de que a certeza não é possível:

À medida que vamos aprendendo com os erros que cometemos, o nosso conhecimento aumenta, embora possamos nunca vir a saber - isto é, a saber com certeza. Uma vez que nosso conhecimento pode crescer, não pode haver aqui razão para desesperar da razão. E, uma vez que não podemos nunca saber com certeza, não pode haver aqui autoridade para qualquer reivindicação de autoridade, nem para qualquer vaidade ou presunção acerca do nosso conhecimento. (Popper, 2006, p. 9-10)

Sendo assim, se, do mesmo modo que Flaubert conclui, não é possível fazer qualquer afirmação, é exatamente na atividade crítica, na discussão dos limites do saber e em seu emprego, que estaria a potência da Ciência, no fato "de podermos discutir a sua pretensão de resolverem os nossos problemas melhor do que as suas adversárias". (Popper, 2006, p. 10)

Prosseguindo nessa discussão dos limites e do uso do conhecimento - ou do saber -, retomemos, por um instante, a questão levantada por Foucault em "La Bibliothèque Fantastique". Seria Bouvard e Pécuchet, da mesma forma que La Tentation de Saint Antoine, um "livro feito de livros"? 
Como vimos acima, acreditamos que a repetição em BP seja a repetição do fracasso. Embora saibamos que a elaboração do romance demandou inúmeras leituras, sugerimos que o romance articula o tratamento dos saberes à noção de impasse, caracterizado pelo fracasso, e pela repetição, a retomada da busca. Mesmo do ponto de vista da narrativa de BP, não são as fontes (livros, opiniões correntes ou notícias) do conhecimento que importam, mas sua reelaboração, exemplificada pelo deslocamento físico ou pelas experiências que envolvem o corpo dos personagens. As fantasmagorias da Tentação são a nosso ver de outra ordem, pois fundadas em conhecimento mítico, vinculado a uma tradição, um livro sagrado, que dá lugar a uma miríade de textos que se relacionam com o Texto. No caso de $\mathrm{BP}$, não há autoridade no conhecimento, seja qual for sua fonte. Essa visão encontraria eco numa afirmação de Popper, que permitiria conectar esse aspecto ao da indecidibilidade:

Mas quais são, afinal, as fontes do nosso conhecimento?

A resposta, creio, é esta: o nosso conhecimento tem fontes de todo o gênero, mas nenhuma tem autoridade. (Popper, 2006, p. 44)

O conhecimento para Popper independeria de sua fonte, pois o importante é a possibilidade da verificação de dada afirmação:

Com efeito, se tivermos dúvidas sobre uma dada asserção, o procedimento normal seria testá-la, e não indagar sobre suas fontes; e, se encontrarmos uma corroboração independente, é muito possível que aceitemos a asserção sem nos preocuparmos minimamente com as fontes. (Popper, 2006, p. 43)

Com o que retornamos à clássica pergunta: Bouvard e Pécuchet são mesmo bêtes, ao não assumir o conhecimento como dado e levarem sua busca ao limite? Ou sua bêtise não estaria, cinicamente, apontando a arrogância daquele que julga saber? Pois ambos testam, sem aceitar passivamente. Entretanto, parecem não perceber a impossibilidade de uma conclusão.

Como consolo, surge um mode d'emploi possível, sugerido por Karl Popper, que, se não resolve a impossibilidade de um conhecimento positivo, permite um possível otimismo sobre a relação entre saber e ignorar:

O que deveríamos fazer, creio eu, era renunciar à ideia de fontes últimas do conhecimento e admitir que todo o conhecimento é humano; que o nosso conhecimento está misturado com nossos erros, os nossos preconceitos, os nossos sonhos e as nossas esperanças; que tudo o 
que podemos fazer é tactear em busca da verdade, mesmo que ela esteja fora do nosso alcance. Podemos admitir que esse nosso tactear é muitas vezes inspirado, mas devemos manter-nos em guarda contra a crença, por muito enraizada que esteja, de que a nossa inspiração comporta alguma autoridade, seja ela divina ou de outra natureza. Se desta forma admitir-mos que, por muito longe que tenhamos ido na nossa descoberta do desconhecido, não existe qualquer autoridade dentro de toda a esfera do nosso conhecimento que se encontre fora do alcance da crítica, poderemos então, sem risco, reter a ideia de que a verdade está para além da autoridade humana. E devemos retê-la, pois sem esta ideia não pode haver nenhum critério objectivo de investigação, nenhuma crítica de nossas conjecturas, nenhuma exploração do desconhecido, nenhuma busca de conhecimento. (Popper, 2006, p. 52)

A visão de progresso como algo não necessariamente benéfico, já que não é possível saber a priori o resultado do avanço (da mesma forma que não se pode antecipar o avanço científico, ou, como afirmado por Popper, não se pode prever o desenvolvimento futuro do conhecimento humano), pode ser conjugada a outra, esta relacionada à imagem do labirinto, em que se sugere que o progresso não ocorre apesar dos impasses e do percurso não-linear, mas exatamente em função desses obstáculos e do desafio ao avanço. Nesse ponto, o pessimismo em relação em relação ao desenvolvimento da técnica e das ciências, que não podem garantir a melhoria das condições de vida do homem contemporâneo a elas, alia-se a um suposto otimismo que, por sua vez, é irrealizável, pois não é possível sua afirmação. Acreditar-se na possibilidade de um "progresso" como decorrente da própria relação com o processo de sua busca surge, em última instância, apenas como uma crença, que pode ser afirmada apenas enquanto lugar comum: o significado da vida é o significado que (se acredita que) se dá a ela.

Finalmente, retomaremos aqui alguns conceitos relacionados à música, mas a outras formas musicais, o minimalismo e a música eletroacústica e concreta.

O termo música minimal tem sido aplicado, desde o final dos anos 60 , a determinado tipo de composições, essencialmente de origem norte-americana, nas quais o material musical (melódico, rítmico ou tímbrico) é extremamente limitado, e os processos utilizados para a transformação desse mesmo material são reduzidos ou nulos. Considerando primordial o fato de que cada som musical deveria ser apreciado por sua própria essência, não tendo que se relacionar necessariamente com outros sons para ser interessante, cada evento sonoro é prolongado durante um longo período de tempo, para que a experiência se dê de uma maneira eficaz. Dessa forma, o ouvinte terá tempo para pesquisar o "interior" desse som, tornando-se possível perceber certas características ou qualidades que o tornam interessante e que eventualmente poderiam passar despercebidas. 
Por outro lado, no campo da música concreta e eletroacústica, temos o conceito de objeto sonoro, que pode ser definido como um acontecimento temporal sonoro com uma duração e uma forma fixa ou variável. Um objeto sonoro pode ser também definido como aquele acontecimento sonoro com uma "gestalt temporal" bem definida. Podemos ouvir os sons como índices (relacionados à sua fonte de origem), ou pelas significações das quais ele é portador, ou enfim, escutar o som por ele mesmo, tomando uma atitude muito particular que chamaremos "escuta reduzida". Esta escuta só se liga aos efeitos do som: forma e matéria do objeto que percebemos. É por essa escuta reduzida que temos consciência do objeto por ele mesmo, que nos esforçamos em descrevê-lo por confrontação com outros objetos. Descrever um objeto é falar de sua forma, compará-lo com outros é definir seu tipo.

Como reelaboração da questão levantada anteriormente sobre a repetição, gostaríamos de sugerir uma aproximação dessa ideia com a repetição minimalista e a escuta reduzida, adequando esses conceitos aos estudos literários e, acreditamos, apontando para possibilidades de desdobramento deste trabalho.

Ao afirmar o intento de repetir incansavelmente a mesma situação, Flaubert parece prenunciar o programa minimal de permitir ao ouvinte - no caso, ao leitor mais tempo para desfrutar do material apresentado. Nas repetições, mais que o mero cômico "vazio", que seria oposto a um cômico "de ideias", teríamos um dispositivo que visaria mobilizar e possibilitar a geração de sentidos, pela exposição prolongada e reiterada desse material. Seria essa mais uma forma de acrescentar instabilidade e dúvida. Conjugada a essa repetição significativa, temos o aspecto de montagem, pois a repetição ocorre em termos de fragmentos que podem ser reconhecidos, ou seja, que apresentam identidade própria, mas que adquirem novas significações no complexo formado pelas repetições.

Já em termos de conjectura, gostaríamos de levantar duas possibilidades: primeiramente, relacionar o objeto sonoro e a ideia de essência, que será discutida mais adiante; por outro lado, associar a dificuldade da fruição do texto de Flaubert, levantado por ele em sua correspondência, ao afirmar que o romance seria apenas para poucos refinados, e relacioná-la a um ato da leitura próximo da escuta reduzida. Se os eventos perdem, em Flaubert, o espaço central da narrativa, cedendo seu lugar ao tratamento linguístico do texto literário, a "nova" leitura que responderia a esse novo fazer literário por meio da fruição dos efeitos desse texto. Embora por caminho bastante diferente, chegamos a conclusão semelhante às de 
diversos teóricos da literatura do século 20. Parece-nos, no entanto, que o percurso percorrido aqui apresenta solidez conceitual, ao apropriar-se dos desenvolvimentos teóricos de outras formas artísticas, ou seja, de outros saberes que não o literário. Retomemos, então, aquela vereda. 


\subsection{INTERSTÍCIOS DO PROCESSO}

Nesta seção será feita a análise do impasse do ponto de vista do processo de escrita, partindo-se de considerações de Roland Barthes, Anne Herschberg Pierrot e Pierre Marc De Biasi.

Roland Barthes (1972) afirma em "l'Artisanat du style" que por volta de 1850 ocorre a emergência da écriture como artesanato desenvolvido em torno do estilo, ou seja, o reconhecimento daquela se daria em função do trabalho nela incorporado. Teria havido nesse período a substituição da imagem do "gênio" criativo pela figura do escritor que submete a inspiração ao trabalho exaustivo, definição semelhante àquela célebre de "gênio", de Thomas Alva Edison (1847-1931), constituído na frase do inventor americano por um por cento de inspiração e noventa e nove por cento de transpiração.

Parece-nos que, para Barthes, a função desse trabalho artesanal do estilo seria a um só tempo a criação e a expressão de um código que ocasionasse a formação de uma corporação, um sentido de pertencimento àquilo que se poderia chamar (anacronicamente) sistema literário, ou seja, situando o processo de escrita numa tradição de produtores e consumidores de literatura, que, mesmo que se suponha criada numa fratura com uma tradição mais ampla, mantém com ela uma relação de espelhamento.

Flaubert teria sido o fundador dessa nova visão da escrita, baseada em empregos do material linguístico como signo do fenômeno literário, como algo diferente de si mesmo, que funciona como definição do próprio estatuto do texto como Literatura:

Flaubert a fondé une écriture normative qui contient - paradoxe - les règles techniques d'un pathos. D'une part, il construit son récit par successions d'essences, nullement selon un ordre phénoménologique (comme le fera Proust); il fixe les temps verbaux dans un emploi conventionnel, de façon qu'ils agissent comme signes de la Littérature, à l'exemple d'un art qui avertirait de son artificiel (...) (Barthes, 1972, p. 51-52)

Tentaremos extrair do trecho aquilo que poderia caracterizar uma escrita flaubertiana. Inicialmente, temos a ideia do estímulo à sensibilidade do leitor (pathos), baseada numa écriture normativa, ou seja, num procedimento codificado, que contém em seu bojo suas próprias regras. Essa codificação é explicitada: a 
narrativa é construída tendo como base sucessões de essências, que compreenderemos aqui no sentido aristotélico, como o conjunto de qualidades, propriedades e predicados universais que caracterizam a natureza própria de um indivíduo concreto.

Essas essências não são apresentadas segundo uma ordem fundada em uma consciência. A convenção dos tempos verbais, citada por Proust em "À propos du 'style' de Flaubert”, marcaria o caráter de construção do texto literário, não apenas em termo dos tempos verbais; outras categorias gramaticais assumiriam o papel de "código", com diferentes funções, segundo o emprego e o efeito desejados:

Le subjectivisme de Flaubert s'exprime par un emploi nouveau des temps des verbes, des prépositions, des adverbes, les deux derniers n'ayant presque jamais dans sa phrase qu'une valeur rythmique. Un état qui se prolonge est indiqué par l'imparfait. Toute cette deuxième page de L'Education (page prise absolument au hasard) est faite d'imparfaits, sauf quand intervient un changement, une action, une action dont les protagonistes sont généralement des choses ("la colline s'abaissa", etc.) Aussitôt l'imparfait reprend : "Plus d'un enviait d'en être le propriétaire", etc. Mais souvent le passage de l'imparfait au parfait est indiqué par un participe présent, qui indique la manière dont l'action se produit, ou bien le moment où elle se produit. (Proust, 1971, p. 76)

Assim, ao mesmo tempo em que "l'art flaubertien s'avance en montrant son face du doigt" (Barthes, 1972, p. 52), por meio do uso idiossincrático das categorias gramaticais, a escrita flaubertiana teria como base o ritmo próprio ao texto, apartado da dicção da fala, o qual estimularia um "sexto sentido literário", partilhada por aqueles que produzem e aqueles que consomem o objeto literário (idem).

Em "Flaubert et la phrase", escrito em 1967, Barthes, de certa forma, retorna sobre seus passos. O "trabalho do estilo", que substituíra o gênio inspirado, teria surgido bem antes de Flaubert, mas adquire neste outro aspecto, o de uma dor absoluta, infinita, inútil (Barthes, 1972, p. 131), que, no entanto, oferece a possibilidade de uma retomada:

(...) lorsque le fond de la peine est atteint, Flaubert se jette sur son sofa: c'est la "marinade", situation d'ailleurs ambiguë, car le signe de l'échec est aussi le lieu du fantasme, d'où le travail va peu à peu reprendre, donnant à Flaubert une nouvelle matière qu'il pourra de nouveau raturer. (Barthes, 1972, p. 132)

A imagem do trabalho extenuante da rasura que atinge seu paroxismo associa-se à ideia do impasse. Após longas horas pouco produtivas, o escritor não pode continuar e joga-se sobre o sofá. Mas é preciso continuar; na prostração do 
impasse brota a alternativa, que não necessariamente é o falseamento de uma proposição anterior. Em outras palavras, o impasse seria o esgotamento de uma linha de pensamento, mas esse esgotamento não é definitivo. Essa linha pode ser abandonada, mas também pode ser retomada, partindo-se de outro - ou do mesmo - ponto de vista, até que um novo impasse intervenha, até que se chegue ao último impasse, o fim da escrita, que abre espaço para novos impasses, dessa vez na leitura.

Prosseguindo, Barthes explora a relação na escrita flaubertiana, da prosa com o verso. A poesia seria a um só tempo desafio e alvo, não apenas para igualá-la, mas para integrá-la à prosa:

(...) la poésie tend à la prose le miroir de ses contraintes, l'image d'un code serré, sûr: ce modèle exerce sur Flaubert une fascination ambiguë, puisque la prose doit à la fois rejoindre le vers et le dépasser, l'égaler et l'absorber. (Barthes, 1972, p. 133)

O ritmo que excitaria o "sexto sentido literário" parece ser retomado aqui, pois as restrições da poesia citadas parecem referir-se à métrica codificada. $O$ problema de Flaubert seria como proceder a essa síntese, em que a prosa, paradoxalmente, iria além das restrições da poesia, ao mesmo tempo em que absorveria sua carga expressiva; seria esse, talvez, o auge da Arte, conjugar a objetividade das condicionantes poéticas à liberdade da narrativa, extraindo assim, a um só tempo, uma perfeição formal almejada e um grau de expressividade ímpar, em que forma e conteúdo, escrita e vida formassem um todo indissociável.

É interessante notar o papel do trabalho com um material limitado (condicionado) e relacioná-lo à liberdade possível no interior dessa própria limitação. A imposição de restrições ao material do qual o escritor se serve dá, ao mesmo tempo, liberdade virtualmente infinita, ao obrigar a busca constante por novas soluções para o tratamento desse material. Como um pintor que empregasse apenas uma única forma geométrica ou cor, ou um músico que compusesse com apenas um material sonoro ou tessitura restrita, não como exercício de estilo, mas como busca de uma expressividade ímpar, exigindo do espectador/ouvinte uma nova sensibilidade, necessidade surgida da quebra de um paradigma de fruição do objeto estético.

As "constantes" oriundas desse processo, seja a forma geométrica, o material sonoro, a tessitura ou a sujeição da prosa às regras da poesia (da arte) formariam a 
base de um vocabulário técnico específico, a partir do qual o processo criativo exerceria escolhas entre alternativas relativamente limitadas. Natural, portanto, a hesitação, a característica de trabalho físico, extenuante, pois não há mais espaço para o gênio inspirado pela musa. Se, por um lado, a possibilidade de uma liberdade relativamente ampla com o material disponível para o fazer artístico sugere também uma probabilidade maior de expressão, parece-nos que, ao proceder à limitação desse material, novas formas de expressividade podem ser produzidas, até mesmo pelo estranhamento ocasionado pela ruptura com a tradição, ou seja, pela quebra de expectativas daquele que frui do objeto de arte.

Parece-nos, no entanto, que Barthes não segue essa linha de pensamento. Ao afirmar que “... (c)omme odysée, l'écriture flaubertienne (...) se restreint donc à ce qu'on appelle communément les corrections du style" (Barthes, 1972, p. 133), que incidiriam sobre a estrutura da linguagem, sobre um código originário, ocasionando uma "linguistique des corrections" (idem), temos a impressão de subordinação do trabalho artesanal da escrita a uma desestabilização do próprio material da criação literária, a língua. Esse trabalho é abordado do ponto de vista da correção no processo da escrita.

Barthes (1972, p. 133-135) explora uma tipologia das correções, associandoas aos dois eixos do papel, sendo que cabe reter aqui a impossibilidade sugerida de uma "terceira dimensão" do escrito, que vá além de seu plano. Esses eixos seriam o vertical, caracterizado pela substituição de palavras (o eixo paradigmático de Saussure) e o horizontal, em que há a adição ou supressão de sintagmas, agindo sobre sua combinação (o eixo sintagmático de Saussure).

$\mathrm{Na}$ escrita flaubertiana, as correções são descritas por Barthes como sendo de dois tipos: as substitutivas da forma, ou seja, do elemento fônico repetido, constituem trabalho árduo, infinito, pois a substituição de uma palavra geraria novas repetições e novas substituições, "tout en gardant le contenu" (Barthes, 1972, p. 135). Supõe-se assim uma disjunção entre forma e conteúdo, com uma sujeição daquela.

Além das substituições de palavras, são descritas também as correções paradigmáticas, que visariam as articulações do discurso, a fim de obter "la fluidité, le rythme optimal du cours de la parole, le 'suivi', en un mot, ce flumen orationis réclammé déjà par les rhétoriciens classique" (Barthes, 1972, p. 136). O encadeamento de ideias é submetido a essa fluidez e não a uma relação lógica, 
ocasionando problema similar ao da substituição vocabular, pois ao buscar na frase o equilíbrio entre o retraimento circular e a dilatação, cai-se num processo infinito de ajuste entre contração e dispersão, centrado num elemento ao qual Flaubert teria dado "une existence technique et métaphysique d'une force inégalable (...)" (Barthes,1972, p. 137), a frase.

Temos assim um trabalho, extenuante, ao longo de dois eixos, visando estabelecer uma unidade que caracterizaria a frase flaubertiana, objeto autônomo cuja unidade recai sobre o projeto subjacente que Ihe dá origem. É o próprio Barthes que apresenta a contradição - e, consequentemente, o impasse advindo dessa definição circular:

Travaillons à finir la phrase (à la façon d'un vers), dit implicitement Flaubert à chaque moment de son labeur, de sa vie, cependant que contradictoirement il est obligé de s'écrier sans cesse (...): Ça n'est jamais fini. La phrase flaubertienne est la trace même de cette contradiction (...) elle est comme l'arrêt gratuit d'une liberté infinie, en elle s'inscrit une sorte de contradiction métaphysique: parce que la phrase est libre, l'écrivain est condamné non à chercher la meilleur phrase, mais à assumer toute phrase. (Barthes, 1972, p.138)

Diferentemente do que vimos anteriormente, aquilo que entendemos como liberdade advinda do uso de um material limitado, nossa leitura de Barthes parece sugerir antes um material ilimitado, exaustivamente trabalhado pelo escritor até atingir um momento de limite voluntário, a parada arbitrária e enfática, sinalizando não um fim, mas a aceitação de uma abertura infinita.

Entretanto, acreditamos ser possível integrar as duas visões. Se, como afirmado por Barthes, a escrita de Flaubert tem por base aquele ritmo próprio ao texto e que se diferencia daquele da fala, por um lado, e emprega convenções de emprego das diferentes categorias gramaticais, por outro, indica-se uma restrição ao universo de frases possíveis, pois forma e conteúdo imbricados deveriam obedecer ao projeto.

A nosso ver, é dentro dessa limitação, no bojo de um projeto que lida com a construção de essências, que se exerce a liberdade infinita do escritor de elaborar frases e de escolher o ponto discricionário de parada, ou, empregando um paradoxo, um "final intermediário", um ponto de repouso que não se confunde com um fim absoluto, com uma conclusão, pois esse ponto de parada potencializa novas tensões. 
Anne Herschberg-Pierrot (1999), num estudo genético do incipit de BP, o qual em sua forma mais conhecida teria sido escrito nos primeiros dias de agosto de 1874, afirma que esse ponto estratégico do texto forma uma unidade semântica e rítmica, fechada em si mesma e delimitada pela pausa após o ponto final. Isso vem em apoio às nossas observações anteriores, como exemplificado a seguir:

L'hésitation sur le chiffre "trente-trois" (...) répond à des raisons complexes parmi lesquelles figurent l'importance du rythme chez Flaubert, mais aussi, comme emblèmes du roman, le thème de la dualité et la satire du discours des sciences. (Herschberg-Pierrot, 1999)

Além de considerações em torno da importância da primeira frase e a afirmação de que texto publicado e estudos genéticos confirmam a centralidade do esquema dual dos nomes e dos personagens que aparece como elemento matricial do texto, Herschberg-Pierrot constata que as diferentes formas de incipit encontradas nos manuscritos de Flaubert estabelecem modelos de abertura possíveis, a partir dos quais se desenvolve o texto.

Se Barthes afirma a frase como unidade do artesanato flaubertiano, a autora citada anteriormente a reafirma como unidade mínima. Definida por Flaubert como "sistema de combinações prosódicas e rítmicas", a frase não constitui, no entanto, elemento que possa ser isolado do "trabalho de significância" (Herschberg-Pierrot, 1999, trad. nossa), pois se subordina ao projeto.

Pierre-Marc de Biasi (2001) sustenta que a origem dos textos de Flaubert encontra-se quase sempre em projeto antigo, que, ao ser retomado, é elaborado e constitui um programa operacional. Em seguida, ocorreria uma atividade de "devaneio" criativo em torno de seu tema, devaneio objetivo, que visa construir, antes do início da escrita propriamente dita, "jusqu'à ce que Flaubert parvienne à voir nettement se dérouler le 'film' du récit” (Biasi, 2001). A partir desse "roteiro mental" ocorreria o trabalho de documentação, que the permitiria situar o projeto, construindo-Ihe "l'atmosphère, l'intertexte et le cadre historique" (idem), para só então proceder ao detalhamento em seus roteiros, que funcionará como guia ao longo do trabalho de escrita. Do roteiro ao rascunho, o plano inicial seria elaborado, adensando-se e sendo reescrito, enquanto aqui e ali algumas frases vão adquirindo sua forma. Em determinado momento, surge o impasse, 
(...) l'écriture se bloque: que voient de la fenêtre de leurs fiacre, les personnages qui se rendent, $d u$ lieu $X$ où ils se trouvent maintenant, au lieu $Y$ où ils doivent être deux pages plus loin? (Biasi, 2001)

Faz-se necessária a informação. Nem a acumulação factual de dados, nem a pesquisa bibliográfica escondem um pretenso intento realista de Flaubert, segundo de Biasi. O objetivo do sábio de Croisset seria produzir uma visão interna, segundo os pontos de vista específicos, não apenas em sua especificidade, mas naquilo que podiam possuir de divergente, "comme si le réel s'observait à travers eux, de l'intérieur même du roman" (Biasi, 2001). Ou seja, busca-se integrar a um só tempo a afirmação e seu possível contrário, ou, recorrendo-se à linguagem cinematográfica, o plano e o contra-plano, inseridos num real construído tendo como base a própria simultaneidade de pontos de vista.

Essa simultaneidade pode ser compreendida como a integração do leitor enquanto virtualidade, pois esse seria obrigado a escolher entre pontos de vista, aderindo ora a um deles, ora a outro, participando da produção de sentido infinita do texto, no que poderia ser associado a uma terceira dimensão do texto escrito, aquela em que o texto encontra o leitor, ou melhor, o espaço entre o texto e o leitor, onde ocorreria a atualização do texto, a criação efetiva da significância potencial.

Já com uma quantidade considerável de texto produzida, Flaubert realizaria o percurso inverso, eliminando e condensando o texto, seguindo-se as correções, ao teste da leitura em voz alta (o famoso "gueuloir"), chegando-se, após inúmeras rasuras e contrações, ao "manuscrito definitivo"68, o qual constituiria passo crucial do processo de criação, o "trabalho sintético do estilo":

\footnotetext{
Une prose réduite à l'essentiel dans laquelle tout doit tenir: les possibles du récit explorés dans les brouillons, la structure narrative, l'économie symbolique du récit, la productivité des ellipses, la mémoire de l'intertexte, le réseau des images, la problématisation du sens, etc., bref, une machinerie complexe des significations que, à travers le texte publié, sera proposée au lecteur comme une partition offerte à ses propres talents de rêverie et de création interprétative. (Biasi, 2001)
}

Parece-nos que a leitura de Biasi sugere, ao exteriorizar a complexidade da escrita de Flaubert, a própria ideia de efeito de conjunto explicitada na correspondência. O complexo narrativo atenderia a um desígnio de ordem mais alta que a da frase, fruto de um projeto que teria início nos devaneios dirigidos e que

\footnotetext{
${ }^{68}$ Simplificamos aqui o processo detalhado por de Biasi, ao qual remetemos para maiores detalhes.
} 
seria reelaborado ao longo do processo, que levaria inicialmente a uma expansão da escrita, seguida por sua condensação, que incorporariam em si reescritas e rasuras, segundo uma busca de uma essência, da máxima concentração de efeito.

Essa concentração de efeito seria, assim, a manifestação de conjunto, do texto como bloco significante, de sua mobilização em todos os níveis. Ao sugerir a importância do efeito de conjunto, parece-nos lícito supor que Flaubert sugere um rompimento da linearidade do significante, representada na escrita pela linearidade no espaço, aproximando-se das linguagens, como a pintura, baseadas em significantes não lineares, que poderíamos associar às essências.

O projeto de Flaubert poderia ser visto, então, como visando o texto como totalidade, baseado não na frase, mas em essências, indefiníveis a priori, mas que excitariam uma percepção no leitor de uma sensação estética, partilhada por produtores e consumidores do texto, estruturadas segundo um código formal e trabalhadas em função desse mesmo projeto. Acepção que reflete novo impasse, já que baseada em categorias que fogem à possibilidade de sua descrição, por sua circularidade: como conceituar, em abstrato, as essências, ou a sensação estética do espectador/leitor, ou definir um código que emana de um texto que se define em função desse mesmo código?

Retomando o texto de Herschberg-Pierrot, observamos que, até esse ponto não levamos em conta os aspectos intertextuais do texto. É interessante notar que a análise genética efetuada revela a necessidade de se colocar outras questões a seu respeito, de sua inserção numa tradição, num contexto de enunciação, e de sua recepção pelo leitor:

L'approche génétique explicite ainsi les virtualités du texte en train de s'écrire. Elle souligne le
dialogue intertextuel qui s'établit entre le seuil du roman et les modèles possibles d'incipit, un
dialogue avec le roman antérieur: celui de Balzac, de Stendhal, mais aussi les incipits
flaubertiens avec lesquels il est en relation mémorielle. L'étude génétique de l'incipit appelle
ainsi une approche poéticienne, qui se pose la question du "comment", mais elle ne peut éviter
l'interprétation sociocritique qui se pose la question du "pour qui" et du "pour quoi", des modèles
de lecture proposés, du savoir implicite du lecteur qui est associé à la lecture de l'incipit.
L'inscription de la causalité parodique en attaque du roman pose d'entrée le jeu du roman avec
les idées reçues, elle indique un horizon de lecture qui joue avec le modèle du roman réaliste et
le démonte. Elle inscrit d'emblée la réénonciation des lieux communs comme un des modèles
d'engendrement de Bouvard et Pécuchet. (Herschberg-Pierrot, 1999)

Surge a afirmação da necessidade de um estudo que leve em conta um enfoque baseado numa diversidade de questionamentos a respeito do texto, de suas condições de enunciação e de sua relação com o leitor. 


\subsection{MODERNIDADE COMO LABIRINTO}

\subsubsection{IMPASSE E LABIRINTO}

Flaubert aproxima-se daquilo que Adorno chama de romance moderno; as isotopias encontradas no incipit analisado anteriormente levam à conclusão de que, mais que situar o leitor como mero espectador, ele é confrontado com escolhas necessárias, desde que haja sua adesão, ou seja, desde que a leitura mergulhe para além dos estratos superficiais.

Indo além, noções caras ao mundo contemporâneo, como a ausência de certezas num momento em que se afirmava o progresso ilimitado da ciência (relembrando a realização das Exposições Universais ao longo do século 19), imbricado no cerne do texto a ser estudado, aparecem na correspondência de Flaubert de forma bastante próxima do pensamento que poderia ser associado ao final do século 20, à era dos extremos e de incertezas:

Qui vous dit que votre jugement humain soit infaillible? que votre sentiment ne vous abuse pas? Comment pouvons-nous, avec nos sens bornés et notre intelligence finie, arriver à la connaissance absolue du vrai et du bien ? Saisirons-nous jamais l'absolu ? II faut, si l'on veut vivre, renoncer à avoir une idée nette de quoi que ce soit. L'humanité est ainsi, il ne s'agit pas de la changer, mais de la connaître (...) Abandonnez l'espoir d'une solution. (Para Mademoiselle Leroyer Chantepie, 18/5/1857).

Esse "estado de dúvida", que poderia ser considerado decorrência de pessimismo ou desencanto com a condição humana, e sua relação com a escrita afinal, ela é nosso campo gerador de possibilidades - é colocado em questão por Tilby, que, de certa forma, retoma a discussão anterior sobre um projeto flaubertiano coerente, revelado de forma mais clara, segundo ele, pela Tentação de Santo Antão e Bouvard e Pécuchet, sugerindo-o como uma resposta a fatores sociais externos, uma resposta

(...) to the quest of totalisation that was the dominant epistemological obsession in midnineteenth-century France. Both works demonstrate by their very eccentricity, not to say absurdity, the way writing for Flaubert was, for all its obvious external concerns, a profoundly personal enterprise. (Tilby, 2004, p. 16). 
Diversos críticos, com maior ou menor sucesso, tentaram explicitar o cerne da escrita flaubertiana. Schehr, em alguns momentos, ao falar de forma paradoxal em fracasso e no colapso do sentido parece estar se referindo a Samuel Beckett:

\begin{abstract}
The success of Flaubert's writing is in the fact that it attains total failure: there can be no hermeneutic code, there can be no interpretation, nor can there be any successful evocation of an object in time and space. The more precise the descriptions seem to become, the more they are accidental and contingent. Values and meaning collapse at the level of the writing, as it begins to reproduce the collapse of meaning and values for the characters. In the end, there is no solution but to go on, endlessly, working at doing nothing. (Schehr, 2004, p. 218).
\end{abstract}

Apesar do aparente paradoxo (o sucesso por meio do fracasso), a afirmação de Schehr pode conduzir a uma possível saída para o impasse; a impossibilidade de continuar é o próprio imperativo da necessidade do avanço, assim como a besteira constitui fundamento do pensamento. Vale, no entanto, pensar se o sucesso da escrita de Flaubert refere-se à produção de um objeto estético ou à sua condição de texto, aberto ao embate com o leitor, ou, em outras palavras, se o sucesso é relacionado à potencialização da ambiguidade encarnada no texto.

Bertrand (2009) busca um enfoque semiótico daquilo que chama de "um tipo de imanência invasiva da espacialidade", por meio de três conceitos, o localismo, a tópica e a instância. Analisa a figurativização da tópica, tomando como ponto de partida termos da semântica estrutural, afirmando que a baixa densidade sêmica original dos lugares foi tornando-se aos poucos mais densa, "o lugar tornando-se um lugar":

Locus amoenus, portrait, paysage constituent désormais des passages obligés, des morceaux précontraints de discours, une stéréotypie du lieu. C'est alors que le lieu se rapproche du sujet et l'intègre : lieu de la domestication de l'espace, lieu de l'habiter, et pour finir lieu de l'identification réciproque de l'espace et du sujet. (Bertrand, 2009).

Estabelecendo a relação entre a descrição de espaços e sua interdependência com personagens que circulam nesses espaços, Bertrand afirma que:

(...) l'ekphrasis est devenu un topos intégré dans le champ rhétorique (morceau descriptif détachable en somme) qui n'a plus qu'un lointain rapport avec la définition originelle des topoï de l'argumentation efficace". (Bertrand, 2009).

o que caracterizaria um deslocamento de uma retórica da persuasão, cujas bases são a "inventio" e a "dispositio", empregando-se a aproximação entre duas artes 
para atingir seus objetivos, em direção à retórica figurativa, que tem como fundamento a "elocutio", na qual a descrição adquire autonomia.

Essa segunda forma retórica, figurativa, conduz à questão frequentemente estudada da descrição no âmbito do chamado romance realista, no qual a narrativa cede lugar à descrição, ou melhor, a descrição assume preeminência, tornando-se "um dos traços marcantes da história moderna do romance" (Bertrand, 2009). romance, que, nas palavras de Adorno, "foi a forma literária específica da era burguesa", deveria buscar no constrangimento da linguagem aquilo que não é possível dar conta por meio da narrativa (Adorno, 2008, p. 56). Em outras palavras, a vida como experiência articulada e contínua teria sofrido um abalo; a narrativa não mais seria capaz de abarcar essa nova experiência, pois a própria figura do narrador não poderia dominá-la. Trata-se de um mecanismo de crise, aquela da objetividade literária, a qual, ainda segundo Adorno, atinge também o campo da psicologia.

Não é apenas porque o positivo e o tangível, incluindo a facticidade da interioridade, foram confiscados pela informação e pela ciência que o romance foi forçado a romper com esses aspectos e a entregar-se à representação da essência e de sua antítese distorcida, mas também porque, quanto mais densa e cerradamente se fecha a superfície do processo social da vida, tanto mais hermeticamente esta encobre a essência como um véu (Adorno, 2008, p. 57).

Nesse ponto Bertrand encontra apoio em Lukács; é interessante notar que Adorno afirma que Flaubert é o parâmetro de um modelo tradicional de romance, que situa o leitor como espectador diante de um palco italiano, submetido à "quarta parede", ou seja, em que o leitor seria meramente observador passivo da trama que se desenrola a sua frente:

Essa técnica era uma técnica de ilusão. O narrador ergue uma cortina e o leitor deve participar do que acontece, como se estivesse presente em carne e osso. A subjetividade do narrador se afirma na força com que produz essa ilusão e - em Flaubert - na pureza da linguagem que, através da espiritualização, é ao mesmo tempo subtraída do âmbito da empiria, com o qual ela está comprometida. (Adorno, 2008, p.60).

Já Bertrand afirma que os grandes responsáveis pela dissolução da forma romanesca, ou seja, pela ascensão da descrição - e, consequentemente, da figuratividade - como sua base, são exatamente Flaubert e Zola (Bertrand, 2009). Neste último, Bertrand entende que a identidade do personagem funde-se com a identidade do espaço, que determina o universo de possíveis ações e comportamentos. 
A descrição constituiria, assim, o mecanismo que possibilitaria o estabelecimento de categorias de base, que seriam a um tempo suporte simbólico e tópico do conjunto romanesco (Bertrand, 2009), estabelecendo relações de complementaridade entre essas categorias.

Como visto acima, Adorno associa o romance realista, exemplificado por Flaubert, com o palco italiano. Entretanto, no caso específico de Bouvard e Pécuchet, essa aproximação mostra-se problemática.

Para Schvalberg (1999), Flaubert é representante de um estilo "anti-retórico". A tentação de Santo Antão e Bouvard e Pécuchet constituem extremos desse estilo, o primeiro texto aproximando-se mais da chamada retórica clássica, enquanto o segundo reflete a visão do final do século 19, quando, segundo Plantin, a "retórica" foi criticada como sendo uma disciplina não científica e eliminada do currículo da universidade republicana, à época em seus primeiros anos.

Ainda segundo Plantin, essa virada teria ocorrido contra o pano de fundo do fim do Segundo Império, da derrota de 1870 e da necessidade de uma "reforma intelectual e moral". Nesse panorama,

Diante das descobertas positivas da pesquisa histórica, nenhuma posição fundada no bom senso, no consenso, na opinião, na doxa ou nos lugares comuns pode ser seriamente sustentada. O saber retórico não é saber. Além disso, a nova divisão dos conhecimentos especializados é incompatível com a pretensão retórica a fornecer a síntese útil de todos os saberes. (Plantin, 2008. p. 13-14)

Apesar de distanciar-se do entendimento de retórica como mera ornamentação - e o fato de Bouvard e Pécuchet mostrar-se extremamente pobre em relação ao emprego de figuras (basta lembrar a afirmação de Proust: "não há uma única metáfora bela em todo Flaubert"), seu texto parece aproximar-se mais de uma visão mais moderna, baseada numa estrutura serial moderna (Séginger, 2004, p. 8) e que abre espaço para a argumentação, para a presença de opiniões contraditórias e, mais que isso, para a dificuldade de sua reconciliação. $O$ espaço entre saber e ignorar poderia ser preenchido por infinitas combinações, como poderia ser esquematizado por meio do emprego do quadrado semiótica para a análise estática e dinâmica. 


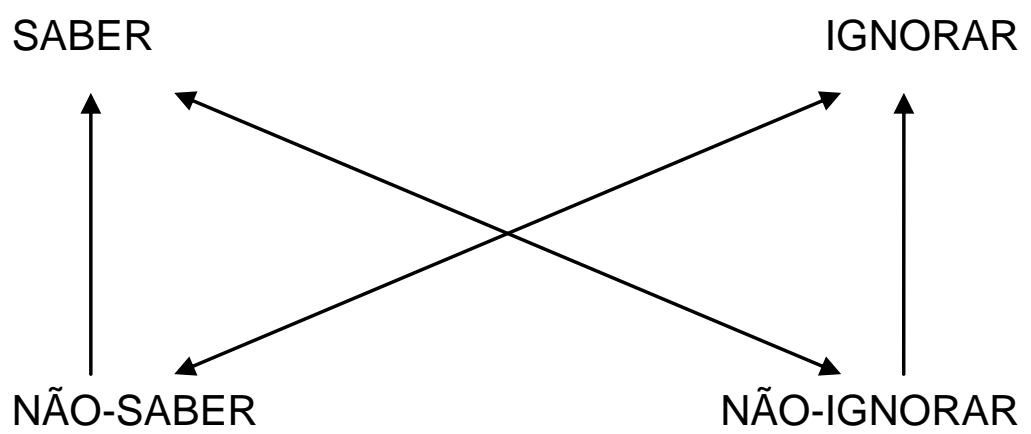

É nesse âmbito que as expectativas do leitor movem-se. Talvez por essa mesma razão, as leituras de Bouvard e Pécuchet se desloquem entre as combinações possíveis. Diferentemente da afirmação de Adorno, o leitor não surge como mero espectador, pois a tensão entre saber-ignorar e suas relações constitutivas, de contradição, contrariedade, subcontrariedade, complementariedade e hierarquia funcionam como "gatilhos", que, por meio da ambiguidade dos diversos elementos narrativos, forçam um papel ativo do leitor na leitura, condizente com as análises do romance "moderno" de Barthes e a visão da leitura de Sartre. 


\subsubsection{BERMAN, FOUCAULT, PERRY ANDERSON: SINTOMAS DA MODERNIDADE}

Como dissemos no início deste trabalho, nossa primeira motivação foi um "sintoma", fenômeno subjetivo, manifestação de certa corrente, que aqui chamamos "moderna", do fazer literário. Nos passos anteriores, tentamos explicitar alguns elementos que poderiam auxiliar na demarcação dessa corrente a partir da leitura de Bouvard e Pécuchet. Nesta seção, partiremos de considerações de Marshall Berman (1986) e do comentário de seu texto feito por Perry Anderson (1986), propondo uma leitura do fenômeno moderno que alia ruptura e tradição.

Não nos preocupa aqui a visão do pensamento moderno num sentido mais amplo, que poderia ser situado em qualquer momento da história das ideias em que se procedeu a uma ruptura com modos de pensar que já não atendiam às necessidades do ser humano.

Nossa linha de raciocínio liga-se, antes, a um fenômeno literário, confrontado a suposto projeto de modernidade, que engloba a um só tempo a ruptura em relação a uma tradição literária, assim como permanências dessa mesma tradição, visando responder aos imperativos de momentos culturais específicos, situados entre o último quarto do século 19 e a primeira metade do século 20.

Não se trata de "revisões" de uma "Querelle des Anciens et des Modernes", do século 17, mas de tentar captar os fenômenos subjacentes às tensões entre "novo" e "velho", pois consideramos que nenhum dos dois elementos ocorre em forma "pura" e, como veremos, é a persistência do velho que forma o quadro conceitual que permite que o "novo" subsista.

Temos, assim, que o "moderno" que buscamos aqui pode encontrar suas raízes bem mais longe; no entanto, ao nos concentrarmos em Flaubert, buscamos uma relação "subterrânea" entre momentos cruciais da história e da historiografia recente, que reuniria criações não pela cronologia, mas por tratamentos que sugerem aproximações e distanciamentos possíveis, caracterizados por sobreposições de realizações múltiplas, pois portadoras de uma diferença individual, que confere novos significados a esses textos. 
Primeiramente é necessário definir nossos termos, já que as denominações "moderno", "modernidade" e "modernismo" são empregadas em diversos contextos e fazendo referência a fenômenos localizados, ou ainda de forma a abranger elementos que não necessariamente dialogam entre si.

A arte dita "moderna" é associada aos primeiros sessenta anos do século 20 , entre as obras da fase cubista de Picasso e os Fauves e os movimentos que expandiram, ao negá-lo, o território e a institucionalização da arte nos anos 60, como a Pop art e o movimento Fluxus, que balizariam o início do chamado "pósmodernismo".

No âmbito da literatura francesa, além disso, o emprego do termo "modernidade" é situado na segunda metade do século 19, graças a Baudelaire. Para Benjamin, a "(...) modernidade assinala uma época; designa, ao mesmo tempo, a força que age nessa época e que a aproxima da antiguidade" (Benjamin, 1986, p. 80) e essa modernidade era atribuída por Baudelaire, segundo o autor alemão, a Victor Hugo. A antiguidade serviria como parâmetro para a construção, enquanto "substância e inspiração são assuntos da modernidade". (idem).

Durante os anos 80, muitos pesquisadores debruçaram-se sobre a questão da modernidade. Entre eles encontramos o filósofo norte-americano Marshall Berman (1940-), de linha marxista. Em um livro que teve grande repercussão quando de seu lançamento, Tudo que é sólido desmancha no ar (1986), Berman descreve aquilo que entende como a espinha dorsal da modernidade, definida como uma experiência partilhada por homens e mulheres, que seria simultaneamente de tempo, espaço, de si mesmo e dos outros, integrando a um só tempo as possibilidades e as ameaças da vida do mundo atual.

Essa experiência dicotômica concentra possibilidades de mudança e destruição de "quase tudo o que temos, tudo o que sabemos, tudo o que somos". (Berman, 1986, p. 15). Para Berman, a modernidade compreendida como experiência anularia fronteiras, fosse geográficas, raciais, de classe e nacionalidade, religião e ideologia, unindo a espécie humana (idem).

Pode-se, assim, compreender a ideia de modernidade como um conceito bipartido, que engloba "desintegração e mudança, (...) luta e contradição, (...) ambiguidade e angústia" onde, citando o Manifesto Comunista de Marx, "tudo o que é sólido desmancha no ar". (idem)

Berman elabora seu objetivo da seguinte forma: 
Minha intenção é explorar e mapear essas tradições, a fim de compreender de que modo elas podem nutrir e enriquecer nossa própria modernidade e como podem empobrecer ou obscurecer o nosso senso do que seja ou possa ser a modernidade. (Berman, 1986, p. 15)

Berman divide a conceito de modernidade em três períodos, sendo que a primeira fase iria do início do século 16 ao fim do século 18. Nesse período ocorrem as primeiras experiências da vida moderna, as transições do capitalismo nascente e a expansão do mundo conhecido. A segunda fase, em que o público que surge depois da Revolução Francesa tem o sentimento de viver em uma era revolucionária (a "Era das Revoluções", de Hobsbawm), caracteriza-se pela nova paisagem industrial decorrente da "revolução dupla", indo até o século 19. Já a terceira fase, no século 20 , vê a mundialização da modernidade, associada aos resultados da expansão do capitalismo em escala global. (Berman, 1986, p. 16-17)

Sujeitos à ambiguidade central do sentido da modernidade, artistas tendem a rebelar-se não apenas em termos artísticos, mas em relação o próprio fundamento desse meio instável. Como afirma Berman:

Todos os grandes modernistas do século 19 atacam esse ambiente, com paixão, e se esforçam por fazê-lo ruir ou explorá-lo a partir do seu interior; apesar disso, todos se sentem surpreendentemente à vontade em meio a isso tudo, sensíveis às novas possibilidades, positivos ainda em suas negações radicais, jocosos e irônicos ainda em seus momentos de mais grave seriedade e profundidade. (Berman, 1986, p. 18)

Cabe notar que entre os grandes modernistas do século 19 citados por Berman não encontramos Flaubert, mas uma lista eclética que inclui Marx, Kierkegaard, Whitman, Ibsen, Baudelaire, Melville, Carlyle, Stirner, Rimbaud, Strindberg e Dostoievski e outros. (Berman, 1986, p. 23). Tal lista demonstra um ecletismo que, se por um lado torna, em princípio, difícil de estabelecer a nota comum dessa "linhagem", por outra oferece uma sugestão de amplitude, que não respeita limites ou barreiras de qualquer tipo, embora, ainda, fenômeno estritamente europeu.

Berman desejava renovar o espírito modernista, pois acreditava que "(...) os modernismos do passado podem devolver-nos o sentido de nossas próprias raízes modernas (...)". (Berman, 1986, p. 34), como forma de recuperação e de atualização da modernidade, numa proposta bastante clara: 
Pode acontecer então que voltar atrás seja uma maneira de seguir adiante: lembrar os modernistas do século 19 talvez nos dê a visão e a coragem para criar os modernistas do século 21. Esse ato de lembrar pode ajudar-nos a levar o modernismo de volta às suas raízes, para que ele possa nutrir-se e renovar-se, tornando-se apto a enfrentar as aventuras e perigos que estão por vir. Apropriar-se das modernidades de ontem pode ser, ao mesmo tempo, uma crítica às modernidades de hoje e um ato de fé nas modernidades - e nos homens e mulheres modernos - de amanhã e do dia depois de amanhã. (Berman, 1986, p. 35)

Temos, assim, um programa que visa a recriação de uma linhagem modernista que permitisse levar adiante o modernismo decadente - para Berman do século 20, graças à influência benéfica da leitura crítica dos modernismos anteriores.

A nosso ver, embora preconize uma linhagem relativamente clara do modernismo, que atravessaria formas de expressão, barreiras linguísticas e nacionalidades, o autor americano parece propor uma atitude do ponto de vista da produção que dialogue com as formas que chamaremos aqui de precedentes, não no sentido cronológico estrito, mas do ponto de vista da crítica e reelaboração do modernismo, no sentido que por ele é atribuído ao termo.

Já o historiador marxista Perry Anderson (1938-), em artigo publicado na New Left Review em 1984, traça uma síntese e um arrazoado do livro de Berman, discutindo a propriedade das noções de moderno e de modernidade.

Anderson argumenta que a ideia de modernização, que afirma estar presente em Berman, pressupõe uma concepção de desenvolvimento como:

(...) um fluxo contínuo em que não há diferenciação real de uma conjuntura ou época em relação a outra, exceto em termos de mera sucessão cronológica do velho e do novo, do anterior e do posterior, categorias que são elas próprias sujeitas a uma incessante permutação de posições numa única direção (...) (Anderson, 1986, p. 6)

No entanto, o historiador britânico contrapõe essa visão àquela que, a seu ver, estaria expressa na obra de Karl Marx. O tempo histórico do modo de produção capitalista caracteriza-se por uma temporalidade "complexa e diferencial, em que os episódios ou eras eram descontínuos em relação uns aos outros e heterogêneos em si mesmos". (Anderson, 1986, p. 6). Tomando com base essa visão, Anderson afirma ser necessária a reconstrução da trajetória do capitalismo para que se compreenda o que significa "desenvolvimento" capitalista, sendo que o próprio conceito de modernização seria um entrave a essa tarefa (idem, p. 6)

A segunda objeção de Anderson ao texto de Berman refere-se ao termo, complementar ao de "modernização", "modernismo". Questionando o fato de Berman 
afirmar que a arte modernista havia florescido com especial vigor no século 20, Anderson opõe a "modernidade" de longo prazo a um fenômeno específico e delimitado temporalmente:

O modernismo, como um conjunto específico de formas estéticas, é, de modo geral, datado precisamente a partir do século 20 , sendo mesmo construído tipicamente em contraste com as formas clássicas, realistas ou outras, dos séculos 19, 18 e mesmo dos séculos anteriores. (Anderson, 1986, p. 6)

Defendendo sua visão, baseada na linha marxista, de uma história que se funda na descontinuidade, Anderson estabelece a especificidade de uma conjuntura como base da impossibilidade de uma noção, a de modernismo, que atravessaria situações históricas diferentes, tornando atuais (no sentido de concretas) outras especificidades, que não admitem redução a elementos comuns, a um mesmo conceito, livre do condicionamento maior imposto pela infraestrutura econômica, ou seja, o termo "modernismo" deveria ser enquadrado "em alguma concepção mais diferencial de tempo histórico". (Anderson, 1986, p. 7)

Seguindo em sua crítica ao texto de Berman, o historiador britânico afirma que não é estabelecida qualquer forma de distinção, seja entre tendências estéticas contrastadas, seja no seio das práticas que compõem as próprias artes. Nesse sentido, é reforçada a ideia de certo "desprezo", por parte de Berman, da especificidade de manifestações que podem ser apreendidas apenas enquanto diferença, excluindo a possibilidade da existência de "uma única Stimmung ["humor", "disposição"] característica, capaz de definir a postura modernista clássica em relação à modernidade". (Anderson, 1986, 7).

Anderson sugere, como alternativa à leitura de Berman, que a compreensão do modernismo consistiria em examinar de forma concentrada "a temporalidade histórica diferencial em que se inscreve", sugerindo o modelo proposto por Lukács, que relaciona as mudanças introduzidas após os movimentos revolucionários de 1848, e os projetos culturais impulsionados ou influenciados pela burguesia, que teria se tornado reacionária na segunda metade do século 19, entrando em decadência ideológica e desembocando no modernismo do início do século seguinte, interpretação, segundo Anderson, execrada pela esquerda (Anderson, 1986, 7). 
Como alternativa ao "perenialismo" de Berman e ao "evolucionismo" de Lukács, Anderson sugere “(...) uma explicação conjuntural para o conjunto de práticas e doutrinas estéticas mais tarde agrupadas como 'modernistas'" (Anderson, 1986, p. 8), explicação que exige a intersecção de temporalidades históricas diferenciadas e que comporiam uma configuração "tipicamente sobredeterminada", gerada por multiplicidade de causas, sugerindo três temporalidades.

A primeira seria a "codificação de um academicismo altamente formalizado", institucionalizado nos regimes oficiais dos Estados dominados pelas aristocracias persistentes, que forma um arcabouço de valores culturais que serviriam como "um conjunto crítico de valores contra os quais podiam medir-se as formas insurgentes de arte" (Anderson, 1986, p. 9) e, ao mesmo tempo, uma base em função das quais elas podiam articular-se entre si. A segunda, lembrando que o "modernismo" de que trata Anderson é aquele do século 20, ligado às tecnologias e invenções da segunda Revolução Industrial, que estimulavam a imaginação das vanguardas. A terceira refere-se à "proximidade imaginativa da revolução social", possibilidade que estaria "no ar" durante a chamada Belle Époque, que teria sido a fonte do tom apocalíptico de correntes como o expressionismo alemão.

O modernismo europeu nos primeiros anos deste século [refere-se ao século 20] floresceu assim no espaço situado entre um passado clássico ainda utilizável, um presente técnico ainda indeterminado e um futuro político ainda imprevisível. (Anderson, 1986, p. 9)

A partir das considerações de Berman e Anderson, podemos tentar construir uma definição que nos seja útil para o estudo de Bouvard e Pécuchet, que permitisse, a um só tempo, integrá-lo a uma linhagem moderna mais restrita, relacionando-se à ideia de modernidade do primeiro num horizonte mais restrito, entre a metade do século 19 e a primeira metade do século 20, conjugando-a ao seu relacionamento com materiais ditos "clássicos", que continuam a ocupar seu espaço na arte moderna, tanto enquanto "material" para a criação, como funcionando de quadro conceitual a partir do qual os modernistas fundamentam suas criações, tendo como base inovações técnicas imprevisíveis e como pano de fundo um contexto político instável e tenso. 


\section{LINHA E PLANO: DESCONTINUIDADE E SABER}

Poe, em A Filosofia da Composição (POE, 1999), descreve de maneira bastante peculiar seu processo criativo. De forma cartesiana, o autor americano oferece um panorama claro, embora questionável, da gênese de seu poema "O Corvo", partindo do efeito desejado e da busca da originalidade, escolhendo em seguida os recursos técnicos adequados ao seu objetivo.

Apesar de, diferentemente de Poe, ser incapaz de reproduzir os passos progressivos deste trabalho, gostaria de tentar elaborar uma conclusão geral, que faça mais justiça às intenções que ao resultado.

Buscou-se, explicitar os impasses associados à ideia do labirinto, inserindo-a numa tradição de escrita moderna/contemporânea.

A ficção flaubertiana deslegitima o próprio texto, o que, a nosso ver, causa dificuldade inclusive em se lidar com quadros teóricos em relação a um texto que abala a possibilidade de um conhecimento por meio da razão. Partimos, exatamente por isso, dos questionamentos teóricos, ligados à reiteração da ideia do impasse e seus dispositivos e configurações, por meio de um enfoque que absorve saberes de diversas disciplinas, além do conhecimento acumulado nos Estudos Literários. Tomando como base fatores como a bêtise, a acumulação enciclopédica do saber, a cópia e a comicidade, fatores que atuam conjuntamente no texto, foi analisada sua relação com o uso dos saberes acumulados no processo de escrita.

Consideramos que o texto de Flaubert afasta-se da noção de realismo, exemplificada pelo prefácio dos irmãos Goncourt, pois o processo de escrita flaubertiano baseia-se no tratamento linguístico e na produção daquilo que chamamos "essências", ao mesmo tempo mantendo aspectos que permitem a identificação do texto como pertencente a uma tradição literária. $O$ efeito visado por Flaubert estaria na percepção do texto como um todo, gerando um efeito de epifania. Esse efeito seria, além disso, obtido pela repetição incessante da mesma situação, que entendemos ser o fracasso reiterado. Essa repetição encontra paralelos na produção artística, exemplificada nas ilustrações e gravações que acompanham este trabalho. 
Chega-se à noção da bêtise e da repetição como formas de elaboração do objeto estético e de privilégio ao leitor, enquanto gerador de significados no processo de leitura. A apropriação de textos de outras disciplinas, como a Filosofia, auxiliou no balizamento de um possível método para a análise de textos limítrofes. As conclusões foram confrontadas com aspectos atuais, principalmente no que se refere aos novos paradigmas textuais, procurando demonstrar que a base de nossa leitura é baseada neste contexto.

Na sequência, discutimos possíveis desdobramentos para este trabalho. 


\subsection{ALÉM DO LABIRINTO \\ 3.1.1. QUESTÕES DE POÉTICA E ESTÉTICA}

A continuidade constitui o estilo (Carta para Louise Collet, 18/12/1853)

Como julgar uma obra que desafia os padrões geralmente aceitos do que seja um texto literário? Fernando Pessoa tece considerações a esse respeito, sugerindo os pré-requisitos do crítico competente, mas, ao mesmo tempo, afirmando a impossibilidade de julgar uma obra que fuja ao canônico:

Que a obra de boa qualidade sempre se destaca é uma afirmação sem valor, se aplicada a uma obra de qualidade realmente boa e se por "destaca" quer-se fazer referência à aceitação na sua própria época. Que a obra de boa qualidade sempre se destaca, no curso de sua futuridade, é verdadeiro; que a obra de boa qualidade mas de segunda ordem sempre se destaca, na sua própria época, é também verdadeiro.

Pois como há de um crítico julgar? Quais as qualidades que formam não o incidental, mas o crítico competente? Um conhecimento da arte e da literatura do passado, um gosto refinado por esse conhecimento, e um espírito judicioso e imparcial. Qualquer coisa menos do que isto é fatal ao verdadeiro jogo das faculdades críticas. (...)

Quão competente é, porém, o crítico competente? Suponhamos que uma obra de arte profundamente original surja diante de seus olhos. Como a julga ele? Comparando-a com as obras de arte do passado. Se for original, afastar-se-á em alguma coisa - e, quanto mais original, mais se afastará — das obras de arte do passado. Na medida em que o fizer, parecerá não se conformar com o cânone estético que o crítico encontra firmado em seu pensamento. (Pessoa, 1986, p. 284-85)

Passamos, assim, a uma tentativa de explicitação de um possível referencial, que poderá servir de base para futuras análises, tendo em mente essa (relativa) impossibilidade de valoração do novo. Tendo em vista as considerações e leituras realizadas, somos levados a ver o texto como resultado das relações entre suas partes e seu todo. Pode-se suspeitar uma sugestão de coerência nesta relação - 0 problema da intenção. No entanto, preferimos pensar neste jogo todo/partes como um espaço de interações. Não supomos a existência de um significado imanente, que deva ser captado pelo leitor, mas consideramos o texto como espaço de descoberta.

Levando-se em conta as inquietações primeiras que motivaram este trabalho, a importância atribuída às inovações de Flaubert e, principalmente, o alcance dessas inovações, expressas por críticos e escritores diversos no tempo e no espaço que 
absorveram ou interagiram com elas, faz-se necessário um conceito operacional de poética. Como tantos outros termos nos estudos literários, a "poética", de seu caráter normativo/taxonômico em Aristóteles às tentativas mais generalistas posteriores, tornou-se uma nebulosa conceitual. Para Reed (1976), os estudos de poéticas dividiram-se em duas linhas distintas, relacionadas à estrutura do texto, por um lado, e à tentativa do estabelecimento de normas e de um cânone literário, por outro. Para o crítico citado, as poéticas europeias foram concebidas em termos de totalidades e de hierarquias de gêneros, opondo-se à enumeração catalogadora, ocorrendo uma mudança de ênfase na passagem do século 18, do prescritivo e canônico para 0 descritivo e classificador dos séculos 19 e 20; estabelecendo clara diferença entre estudos de poética e crítica literária, afirma: "[...] there is a difference between a poetics, such as Frye's Anatomy of Criticism, and a work of criticism, such as Brooks's The Well-Wrought Urn." (Reed, 1976, p. 101). Elaborando uma definição, Reed observa que:

Explicitly or implicitly, a poetics is concerned with judging literature according to some standard of aesthetic good and bad-whether the judgment is elitist and restrictive, as in the case of Staiger, or democratic and expansionist, as in the case of Frye. (Reed, 1976, p. 102).

No mesmo texto, é questionada a aplicabilidade do termo poética à análise estruturalista, tomando como base os trabalhos de Tzvetan Todorov, que o emprega explicitamente, e Roland Barthes, sugerindo que seu uso para descrever a sistemática desses autores exige o reconhecimento de uma "transvaloração de valores críticos" ["transvaluation of critical values"], tendo havido a substituição do humanismo literário de Aristóteles, Staiger e Frye por um "holismo científico que explicitamente rejeita as suposições humanistas". (Reed, 1976, p. 112, tradução nossa). Finalizando suas considerações, numa interessante proposta, afirma que:

My own suggestion is that we leave aside the question of a poetics of the novel for the time being and look more closely at the way novels place themselves in literary-and extra-literaryhistory. (Reed, 1976, p. 112).

Sugere-se, assim, a importância do estudo da interconexão entre o contexto histórico e o romance, o que parece dialogar com as propostas de Umberto Eco, que serão discutidas mais adiante. 
Outra perspectiva de poética é expressa por Meschonnic, que, de forma incisiva, afirma uma estreita relação entre a atividade da escrita e o estudo do texto literário:

O estudo da obra é então uma poética. Ela não elimina os outros processos exploratórios, posto que se visa à descoberta e não à tautologia. [...] Ela visa à forma como vivido, o "signo" se fazendo "texto". Ela não é separável de uma prática da escrita: é a consciência desta. (Meschonnic, 1970, p. 144, grifo nosso ${ }^{69}$ )

Cabe reter a afirmação de que o trabalho com o objeto é indissociável do trabalho que permite a descoberta desse mesmo objeto, ou, como assevera: "[...] não se pode separar saber de epistemologia: o estudo do escrito de uma reflexão sobre as condições de estudo do escrito." (Meschonnic, 1970, p. 144). O trabalho crítico pressupõe a escrita como aspecto integrante e essencial da busca dos vínculos entre as diferentes unidades do texto, fazendo com que seus diversos níveis sejam refletidos entre si, chegando-se à definição de um procedimento por meio da projeção do paradigmático sobre o sintagmático. De forma programática, afirma que o objetivo maior da poética seria sua utilidade como pedagogia da literatura, inserindo a escrita na prática cotidiana, tornando, enfim, homogêneas sua prática e a vida, assim como a crítica e a escrita (Meschonnic, 1970, p. 144). O complexo escrita/crítica/vida constituiria um veículo de liberação e de desalienação; no entanto, e é esse o ponto que interessa mais diretamente, Meschonnic deixa claro que o objeto de estudo é indivisível e, assim sendo, o estudo dos diferentes níveis não pode se realizar separadamente, e não só não há outra hierarquia entre estes níveis e redes de significação, que não seja a do sentido ou sentidos da obra, como também a obra não é linear, as correspondências se fazendo "fora da ordem temporal seguida pelos elementos". (Meschonnic, 1970, p. 145).

Reterei daqui dois pontos: em primeiro lugar, os sentidos do texto ${ }^{70}$ emergem do jogo de relações entre seus elementos internos, que nele encontram sua justificativa. Em segundo lugar, a prática da escrita é inerente à crítica, configurando

\footnotetext{
${ }^{69}$ Foi empregada nas citações de Meschonnic a tradução Eduardo Viveiros de Castro, publicada em Lima, Luiz Costa (org.). Teoria da literatura em suas fontes. Rio de Janeiro: Civilização Brasileira, 2002, p. 37-51.

${ }^{70}$ Nesse ponto, discordo da proposição de Meschonnic de que a poética deva emanar da obra de um autor, pois é suposta uma coerência ao longo do tempo que considero extremamente difícil de ser defendida, até mesmo no âmbito de um único texto.I
} 
um gesto que também é, embora não visando necessariamente a criação artística, criador.

Já Umberto Eco apresenta uma reflexão bastante rica sobre poéticas. Partindo da noção de poética como o estudo das estruturas linguísticas de uma obra literária - inserindo nessa corrente um amplo espectro, dos formalistas russos até o estruturalismo posterior ao círculo linguístico de Praga, afirma que é Valéry quem estende o emprego do termo para outras formas artísticas, como um "estudo do fazer artístico". (Eco, 2008, p. 24 e ss.). Embora não seja possível abarcar aqui essa possibilidade, é interessante notar que ela se coaduna com a intuição primeira de "algo indizível", comum a Flaubert e a outras artes.

Eco, no entanto, apresenta sua própria noção de poética, vinculada à sua concepção da obra artística como construção objetiva fundamentalmente ambígua. Embora se filie a uma corrente dita "clássica", distancia-se da ideia de prescrição ou norma coercitiva, definindo-a como um

[...] programa operacional que o artista se propõe de cada vez, o projeto de obra a realizar tal como é entendido, explícita ou implicitamente, pelo artista. [...] uma pesquisa sobre as poéticas [...] baseia-se seja nas declarações expressas dos artistas [...] seja na análise das estruturas da obra, de sorte que da maneira como a obra está feita se possa deduzir o modo pelo qual ela queria ser feita. (Eco, 2008, p. 24-25).

Nessa visão, temos que lidar com problema da intençãa ${ }^{71}$ daquele que escreve e de sua efetiva realização. Partir-se de um programa a cumprir ou buscar esse programa na análise estrutural sugere uma suposição de congruência entre projeto e obra. Ora, sem que seja necessário um recurso aos lugares comuns já gastos, muitos projetos e ideias frutíferos geraram fracassos artísticos (de boas intenções...). Umberto Eco trata, no trecho, a obra ${ }^{72}$ como documento que registra um desígnio - mesmo quando fracassado ou "discutíveis do ponto de vista estético"73 - a partir do qual se pode explicar uma fase da história da cultura. (Eco, 2008, p. 25).

Embora partindo de premissas diferentes das de Meschonnic, Eco parece ter em comum a preocupação com a poética como expressão do texto. $O$ ponto

\footnotetext{
${ }^{71}$ Meschonnic fala da diferença entre "intenção" do autor e "intencionalidade" do texto.

72 O nosso "texto".

${ }^{73}$ Eco, no entanto, "concede": "[...] embora, na maioria dos casos, seja sem dúvida mais fácil individuar uma poética mediante a referência a obras que, a nosso ver, atingiram seu propósito".
} 
problemático aqui é se essa expressão liga-se a uma intencionalidade ou ao processo de reverberação entre seus elementos constitutivos e sua totalidade.

Por fim, Édouard Glissant fala em Introduction à une poétique du Divers (Glissant, 1996) sobre a importância da tradução e dos tradutores, que inventam, a seu ver, um forma de expressão transversal entre duas línguas que é similar ao modo que os poetas criam maneiras de expressar-se em sua própria língua. A tradução seria um processo incontornável para que as culturas possam entrar em contato, de forma mutuamente enriquecedora. Mais que isso, a tradução seria um instrumento de crítica - e, traçando-se um paralelo com a proposta de Meschonnic, a tradução poderia vir a ser aquela atividade de escrita indissociável da crítica. Não se quer dizer com isso que a tradução seja essencial à atividade crítica, mas que ela pode ter um papel relevante na explicitação do projeto inerente ao texto, que surge da interação entre os diversos elementos do texto. Tomando emprestada uma formulação do campo das artes visuais, é significante a preocupação de um dos curadores da Bienal de Veneza de 2009 em relação à "fricção" entre artistas cronologicamente distantes:

In what sense are Öyvind Fahlström [São Paulo, 28/12/ 1928 - Estocolmo, 9/11/1976], say, or Lygia Pape [Nova Friburgo, 7/4/1927 - 3/5/2004], or Gordon Matta-Clark [Nova lorque, 22/6/1943 - 27/8/1978] important? Simply in the sense that their works provide productive friction for artists working today. The significance of a work of art is not static, but the result of ongoing re-readings and misreadings, and the meaning of a work of art is also something that is produced retroactively through new works of art (Cezanne is another artist after Cubism). MattaClark, for instance, is certainly of importance for Rirkrit Tiravanija [Buenos Aires, 1961]. But the reverse is just as true: Tiravanija's work is of great importance for Matta-Clark; it gives his work new layers of meaning, keeps it alive and relevant for us today (BIRNBAUM, 2009, grifo nosso).

A leitura/crítica/tradução produz uma "rugosidade" que caminha nos dois sentidos, da obra anterior para a obra atual e vice-versa. Apontar um projeto que emana de um texto poderia resultar numa leitura mais rica se essa rugosidade fosse empregada com esse fim, num processo de iluminação recíproca.

Tendo por base as diversas concepções de poética apresentadas, pode-se, então, tentar estabelecer uma definição preliminar que possa nortear este trabalho. Poética seria a explicitação de um projeto da forma como se encontra expresso num texto, por meio de sua organização estrutural e relacionamento entre seus elementos internos, situando-se tanto essa atividade de descoberta do objeto como também as condições de realização do objeto enquanto tal. A atividade da tradução 
poderia ser empregada nessa explicitação, ao retirar o objeto de seu contexto e inseri-lo em outro, expondo, assim, relações que o transcendam.

Cabe retomar as considerações de Pound acerca daquilo que o poeta norteamericano chamava de método ideogrâmico. Com base numa metáfora que aplica aos textos literários procedimentos das ciências naturais, ele afirma que:

O método adequado para o estudo da poesia e da literatura é o método dos biologistas contemporâneos, a saber, exame cuidadoso e direto da matéria e contínua COMPARAÇÃo de uma "lâmina" ou espécie com outra. (Pound, 1986, p. 23).

Como justificativa a este método, que poderíamos chamar de "contrastivo", Pound expõe o contexto e função social, tanto do texto literário, como também do escritor:

A literatura não existe num vácuo. Os escritores, como tais, têm uma função social definida, exatamente proporcional a sua competência como escritores. Essa é sua principal utilidade. Todas as demais são relativas e temporárias e só podem ser avaliadas de acordo com o ponto de vista particular de cada um. (Pound, 1986, p. 36).

Pound prossegue em sua defesa do método ideogrâmico por meio das analogias com a química e das reações. Embora numa linguagem baseada em metáforas sucessivas, o princípio parece ser o mesmo sugerido pela interação entre artistas defendida por Birnbaum. As conclusões de Pound sugerem um caminho, mas não a direção a seguir:

\footnotetext{
É impossível aferir a ação de um produto químico simplesmente acrescentando-lhe um pouco mais do mesmo produto. Para conhecê-lo é preciso conhecer os seus limites, saber o que ele é e o que ele não é. Que substâncias são mais leves ou mais pesadas, mais elásticas ou mais compactas.

Impossível medir um produto por si mesmo, diluindo-o apenas com alguma substância neutra. (Pound, 1986, p.60).
}

Não se trata, tampouco, de "comparar tudo com qualquer coisa": o programa poundiano tem marcos bem definidos, embora exijam um amplo conhecimento, que não se restringe ao objeto literário. Deve-se comparar "Shakespeare com Dante, ou com Voltaire, Stendhal, Flaubert, ou Fielding - se não souber francês" (Pound, 1986, p. 60).

O método de Pound encontra um defensor em Meschonnic, que afirma, de forma mais concreta, que não se pode iniciar uma nova tentativa, sem que se proceda a uma renovação de uma metodologia, pois não lemos com a palavra alheia 
(Meschonnic, 1970, p. 11), ou seja, a leitura deve embutir um ato de escrita, chegando-se, por meio do confrontamento de textos, a uma análise que ressalte as relações entre elementos e seu princípio unificador (Meschonnic, 1970, p. 15).

É importante ressaltar que a poética de Meschonnic visa uma percepção rítmica, vista como elemento fundamental e definidor do texto enquanto totalidade (Meschonnic, 1970, p. 65). Chega-se, assim, a uma explicitação mais clara do programa que define essa poética, em termos que retomam e dialogam com nossa tentativa de definição:

Ainsi, non à la poursuite des universaux, mais du concret d'une écriture, non science naïve mais pratique théorique, la poétique est l'étude (et l'étude des conditions de cette étude, indissociablement) d'une œuvre objet et sujet, fermée comme système, ouverte à l'intérieur d'elle-même comme créativité, et au-dehors comme lecture - l'étude d'une réthorique visionnée, qui fait qu'une forme est unique. (Meschonnic, 1970, p. 138)

\section{O ponto de partida poderia ser uma definição contemporânea:}

(...) a obra de arte é uma mensagem fundamentalmente ambígua, uma pluralidade de significados que convivem num só significante. (...) tal ambiguidade se torna - nas poéticas contemporâneas - uma das finalidades explícitas da obra, um valor a realizar de preferência a outros, conforme modalidades para cuja caracterização nos pareceu oportuno aproveitar instrumentos fornecidos pela teoria da informação. (Eco, 2008, p. 22)

Temos aí a sugestão de um aspecto que poderia orientar uma pesquisa futura, a busca da forma pela qual a ambiguidade, caracterizada pela informalidade, desordem, casualidade e indeterminação dos resultados (Eco, op. cit.), pode servir de ferramenta para a análise, em outras palavras, de que forma as propriedades do texto permitem leituras diversificadas, mantendo-se o aspecto de coesão. Uma objeção que poderia ser levantada é a autonomia do leitor, ou seja, sendo a leitura o momento crucial da elaboração de um sentido para o texto - sentido cujas possibilidades Eco considera serem coordenadas por ele - a ambiguidade é incontrolável pelo texto, em outras palavras, ela é uma constante em qualquer texto. No entanto, seguiremos com a hipótese de que o caráter ambíguo seja uma finalidade explícita.

Ainda empregando a terminologia de Umberto Eco, sua noção de poética, entendida, como vimos, por "(um) programa operacional que o artista se propõe de cada vez, o projeto de obra a realizar tal como é entendido, explícita ou implicitamente, pelo artista." (Eco, 2008, p. 24) poderá nortear a análise. Essa ideia 
nos auxilia a ligar o objeto de estudo a um aspecto diacrônico, relacionando poéticas. Teríamos, assim, que optar entre nos basear naquilo que o artista diz expressamente - e no caso de Flaubert temos sua vasta correspondência - ou pela análise estrutural dos textos.

Um problema a ser enfrentado está na disposição do filósofo italiano está relacionado às dificuldades impostas pela busca dos indícios de uma intenção. Trataremos, ao longo do desenvolvimento da pesquisa, de problematizá-lo. Mas, de toda forma, o trabalho poderá girar em torno de "esclarecer os projetos de poética para iluminarmos através deles (...) uma fase da história da cultura (...)" (ibidem), sem necessariamente aderir a essa visão.

Retomando, temos, por um lado, a necessidade de um enfoque sintético, que una o aspecto estrutural (linguístico) à sua inserção, enquanto poética, numa história da cultura. Meschonnic, em sua visão da poética, afirma a unidade entre a prática da escrita e o estudo daquilo que chama de obra, a totalidade da produção de um autor (Meschonnic, 1970, p. 144).

Parece surgir a possibilidade de uma abordagem que integre diferentes métodos para a análise, tendo como objetivo a busca de um saber novo. $O$ recurso a diferentes vertentes dos estudos literários, ou de outras áreas do conhecimento humano, na medida em que suas contradições, possibilidades e fundamentos possam auxiliar nesta busca, parece oferecer novos caminhos. Exige, por outro lado, certa ousadia e despojamento, no sentido de se afrontar discursos irreconciliáveis, sem que se saiba ao certo qual será o ponto de chegada. Meschonnic afirma ainda que

\footnotetext{
Não se pode separar o estudo de um objeto do estudo da metodologia da descoberta desse objeto; e não se pode separar saber de epistemologia: o estudo do escrito de uma reflexão sobre as condições de estudo do escrito. (Meschonnic, 1970, p. 144).
}

O objetivo seria, assim, por um lado, estabelecer as relações entre pequenas e grandes unidades do texto, por meio de uma leitura cerrada, próxima da análise textual; por outro, investigar a expressão tácita de uma poética, por meio do estudo dos elementos encontrados na correspondência publicada. Finalmente, num processo de síntese, analisar a relação contextual - a situação do objeto naquilo em que a história da cultura apresentar-se de forma relevante. 


\subsubsection{IL N'Y A PERSONNE ET IL Y A QUELQU'UN}

Embora este trabalho tenha sido desenvolvido no âmbito dos estudos literários franceses, é interessante notar a relação da escrita de Flaubert com três escritores anglófonos que em determinado momento residiram em Paris. O irlandês James Joyce, autor do Ulisses (1922) e do Finnegans Wake (1939), obras que continuam a desafiar a crítica, viveu em Paris a partir da década de 1920. Já o francófilo Ezra Pound (1885-1972), o célebre poeta americano, discutido por sua relação com o fascismo, foi bastante próximo de Joyce durante o período em que viveu na França. Vértice de um triângulo literário, Joyce serviu quase como preceptor do compatriota Samuel Beckett (1906-1989), com quem desenvolve uma relação bastante intensa.

Temos, assim, um escritor e dois escritores irlandeses, de gerações diferentes, que residem em Paris na primeira metade do século $20^{74}$ e que se relacionam de forma profunda com a tradição literária francesa e com o sistema literário francês da época. Beckett vai mais além, lutando na Resistência (por seus amigos e não pela França, diria mais tarde), período em que passa a escrever em francês. Ganhador do prêmio Nobel em 1969, permanece na capital francesa até sua morte.

Beckett conta com um estatuto ambíguo. Irlandês, publica livros em inglês e em francês e, muitas vezes, passa a traduzir os próprios textos, num trabalho de recriação, no sentido da elaboração de algo original, que guarda uma relação de parentesco com a fonte da tradução. Coloca-se, assim, um impasse que se refere à escolha da fonte para a análise e/ou tradução, que lembra a questão da autoria do romance póstumo de Gustave Flaubert.

Trata-se, é claro, de problema específico. O fato que os aproxima é a relativização da noção de "original" e de "texto publicado". Enquanto em Flaubert temos um texto mediado, construído a partir de manuscritos diversos e que em momentos diferentes sofrem interferências de outras pessoas além de Flaubert, no

\footnotetext{
${ }^{74}$ Beckett e Pound encontram-se em Paris apenas em 1929, ocasião em que Pound age de forma pouco amistosa.
} 
caso de Beckett temos "originais" em línguas diferentes, que por vezes se contradizem, gerando possibilidades extrínsecas e intrínsecas de leitura.

Os escritores irlandeses contemporâneos de Samuel Beckett preferiam, por uma série de razões, ligadas, inclusive, ao ativismo político irlandês, Balzac a Flaubert. Seán O’Faoláin (1900-1991), por exemplo, afirma que

Le réalisme de Flaubert est restreint, concentre, détaillé, particulier, limite, II ressemble trop à un évangile littéraire. Nous nous inclinons avec admiration devant Madame Bovary, mais nous préférons le champ plus étendu de Balzac. (Seán O’Faoláin, apud Le Juez, 2007, p. 45)

Tal fato não ocorreu com escritores irlandeses de outras gerações, como Oscar Wilde (1854-1900) e o próprio James Joyce. Pound, por sua vez, afirmava a existência de uma linhagem de prosadores e versificadores, cujo precursor seria Stendhal e o fundador, Flaubert, que poderiam, a um só tempo, esclarecer e representar a potência da escrita moderna.

Embora, aparentemente, Samuel Beckett não houvesse expressado admiração por Flaubert (Le Juez, 2007, p. 9), com frequência é feita uma aproximação entre ambos:

Beckett, lui, a une nette préférence pour le style et les thèmes de Flaubert. Son intérêt commence précisément par l'impersonnalité de son écriture, ce qu'O'Faoláin décrit comme le point de démarcation avec la plupart de leurs semblables. (Le Juez, 2007, p. 46).

No caderno de anotações de aula de Rachel Burrows, estudado por Brigitte Le Juez, encontramos, entretanto, diversos comentários feitos pelo Beckett professor de literatura francesa no Trinity College, da Universidade de Dublin, que permitem esclarecer melhor essa relação entre a escrita de ambos.

Em suas aulas, Beckett critica a lógica rígida e as relações de necessidade, que chama "efeito bola de neve": o encadeamento mecânico, fatal de circunstâncias, a "mise en scène arbitraire du matériau par l'artiste. Pas d'imprévu, pas d'incrédulité, pas d'impulsion" encontradas em Balzac. ( Rachel Burrows, apud Le Juez, 2007, p. 48-52).

Como Flaubert, Beckett "chérit l'impersonnalité de l'auteur et surtout l'absence de finalité dans le texte, seules conditions possible à qui veut tenter d'exprimer, précisément, la condition humaine”. (Le Juez, 2007, p. 49). Temos, assim, que 
Beckett tenta abolir de sua escrita a relação causal lógica como forma de expressão da irredutibilidade da vida.

Neste ponto, podemos confrontar a passagem de Bouvard e Pécuchet que fala exatamente sobre Balzac, associando sua escrita ao trabalho do estatístico ou do etnógrafo, e não do escritor:

L'œuvre de Balzac les émerveilla, tout à la fois comme une Babylone, et comme des grains de poussière sous le microscope. Dans les choses les plus banales, des aspects nouveaux surgirent. Ils n'avaient pas soupçonné la vie moderne aussi profonde.

- "Moi je le trouve chimérique" finit par dire Pécuchet. "Il croit aux sciences occultes, à la monarchie, à la noblesse, est ébloui par les coquins, vous remue les millions comme des centimes, et ses bourgeois ne sont pas des bourgeois, mais des colosses. Pourquoi gonfler ce qui est plat, et décrire tant de sottises ? II a fait un roman sur la chimie, un autre sur la Banque, un autre sur les machines à imprimer. Comme un certain Ricard avait fait "le cocher de fiacre", "le porteur d'eau", "le marchand de coco". Nous en aurons sur tous les métiers et sur toutes les provinces, puis sur toutes les villes et les étages de chaque maison et chaque individu, ce qui ne sera plus de la littérature, mais de la statistique ou de l'ethnographie." (BP, p. )

Além da tradição do romance de Balzac, Beckett critica em seu curso os naturalistas como Zola, por sua "uniformité forcée", devido a "présence d'un système de référence basé sur une seule idée, une seule attitude, d'où la complexité est exclue". (Le Juez, 2007, p. 58)

O primeiro romance escrito em francês por Beckett, Mercier e Camier e Bouvard e Pécuchet possuem semelhanças evidentes, que permitem estabelecer um quadro de referência, um diálogo entre momentos da história cultural que fornecem elementos para que se diga algo a respeito de ambos, reminiscente do método ideogrâmico de Ezra Pound (Pound, 1986, p. 30). Não se trata de efetuar comparação entre textos diversos, mas o objetivo deste método é, pelo confronto, iluminar características, presenças e ausências. Esta escolha visa fugir de uma análise que se perca em abstracionismos e idealizações que acabassem por obscurecer qualquer leitura possível.

Beckett, além de poder ser visto como "herdeiro" de uma tradição, dialoga com ideias presentes na correspondência de Flaubert, como o "livre sur rien":

Car le seul moyen de parler de rien est d'en parler comme de quelque chose, comme le seul moyen de parler de Dieu est d'en parler comme d'un homme. (BECKETT, 1967, p. 78)

Além disso, a opção feita por Beckett pela escrita em francês torna o confronto entre seu texto e o de Flaubert interessante: 
Samuel Beckett transcribed in what he called his 'Sottisier' notebook Charles Parnell's comment, made to John Morley in 1890, that Ireland was 'a very good place to live out of'. Beckett's move to France, and, more radically, his decision in the mid-1940s to work almost exclusively in French, both suggest that he took this principle to heart, distancing himself from his country, his culture and his past. (Barry, 2005, p. 505)

Se em Bouvard e Pécuchet a contradição surge a partir da oposição entre conjuntos de opiniões válidas, sem que haja maneira de reconciliar essas visões (Schehr, p. 217), em Mercier e Camier, primeiro romance escrito diretamente em francês por Samuel Beckett ao final da Segunda Guerra e publicado apenas em 1970, são os próprios fatos e versões que entram em choque, chegando-se ao ponto em que o narrador é obrigado a intervir, sem pudores:

Camier arriva le premier au rendez-vous. C'est-à-dire qu'à son arrivée Mercier n'y était pas. En réalité, Mercier l'avait devancé de dix bonnes minutes. Ce fut donc Mercier, et non Camier, qui arriva le premier au rendez-vous. Ayant patienté pendant cinq minutes, en scrutant les diverses voies d'accès que pouvait emprunter son ami, Mercier partit faire un tour qui devait durer un quart d'heure. Camier à son tour, ne voyant pas Mercier venir, partit au bout de cinq minutes faire un petit tour. Revenu au rendez. vous un quart d'heure plus tard, ce fut en vain qu'il chercha Mercier des yeux. Et cela se comprend. Car Mercier, ayant patienté encore cinq minutes à l'endroit convenu, était reparti se dérouiller les jambes, pour employer une expression qui lui était chère. Camier donc, après cinq minutes d'une attente hébétée, s'en alla de nouveau, en se disant, Peut-être tomberai-je sur lui dans les rues avoisinantes. C'est à cet instant que Mercier, de retour de sa petite promenade, qui cette fois-ci ne s'était pas prolongée au delà de dix minutes, vit s'éloigner' une silhouette qui dans les brumes du matin ressemblait vaguement à celle de Camier, et qui l'était en effet. Malheureusement elle disparut, comme engloutie par le pavé, et Mercier reprit sa station. Mais après les cinq minutes en voie apparemment de devenir réglementaires il l'abandonna, ayant besoin de mouvement. Leur joie fut donc pendant un instant extrême, celle de Mercier et celle de Carnier, lorsque après cinq et dix minutes respectivement d'inquiète musardise, débouchant simultanément sur la place, ils se trouvèrent face à face, pour la première fois depuis la veille au soir. II était neuf heures cinquante.

Soit:

\begin{tabular}{lllllllll} 
& & Arr. & Dép. & Arr. & Dép. & Arr. & Dép. & Arr. \\
\cline { 3 - 9 } Mercier & $\ldots$ & 9.05 & 9.10 & 9.25 & 9.30 & 9.40 & 9.45 & 9.50 \\
Camier & $\ldots$ & 9.15 & 9.20 & 9.35 & 9.40 & 9.50 & &
\end{tabular}

Que cela pue l'artifice. (MC, p. 8-10)

Mercier e Camier, além disso, cristaliza e amplia o conceito do impasse literário no contexto da metade do século 20: "Et de temps en temps ils se regardaient, incapables de prononcer un mot, et l'esprit vide." (MC, p. 26).

O estudo da obra de Beckett surge como possibilidade de aprofundamento da análise da questão do impasse como expresso aqui e mesmo como validação dos passos seguidos e dos resultados obtidos. Além disso, seria interessante 
desenvolver a noção de rizoma, em contraste com a de labirinto, como possibilidade de negações simultâneas, o que certamente será realizado na próxima etapa. 


\section{REFERÊNCIAS BIBLIOGRÁFICAS}

\section{Obras de Gustave Flaubert}

FLAUBERT, Gustave. CEuvres Complètes. Paris : Gallimard - Pléiade, 2001 (1936). . Bouvard et Pécuchet. Paris, Gallimard, 1979 (ed. Claudine Gothot-Mersch). . Bouvard et Pécuchet. Paris: GF Flammarion, 1999. . Bouvard e Pécuchet. São Paulo, Estação Liberdade, 2007 (trad. Marina Apenzeller). . Correspondance. Paris: Gallimard - Pléiade, 1991. . Correspondance. Masson, Bernard (org.). Paris : Gallimard - Folio

Classique, 1998.

. La tentation de saint Antoine. Paris : Gallimard, 2006 (1983) (ed. Claudine

Gothot- Mersch). . Théâtre. Paris : Louis Conard, 1927. L'Éducation sentimentale. Paris : Pocket, 1998. Mersch). . Les mémoires d'un fou. Paris : Gallimard, 2001 (ed. Claudine Gothot. Madame Bovary. Paris : Gallimard, 1972.

Par les champs et par les grèves. Paris : Pocket, 2002. Salammbô. Paris : Flammarion, 1992 (1964). Trois contes. Paris : Le Livre de Poche, 1983.

\section{GERAL}

ADORNO. Theodor. Notas de Literatura 1. São Paulo: Livraria Duas Cidades/34, 2004.

ANDERSON, Perry. "Modernidade e revolução". In: Novos Estudos CEBRAP, n 14, fevereiro/1986, p-2-15. São Paulo.

AUERBACH, E. Mimesis. São Paulo : Perspectiva, 1994.

BAKHTIN, Mikhail. Questões de Literatura e de Estética. São Paulo: Unesp, 1990.

BARBUY, Heloísa. Museus, exposições e cidades : cultura visual no século 19. 18은 Encontro internacional Imagem e Ciência. CNRS/Museu Paulista. Outubro/2002.

BARTHES, R. Le Degré Zéro de l'Écriture. Paris : Seuil, 1972.

. "O Efeito do Real". In: Literatura e Semiologia. Petrópolis: Vozes, 1973.

BENJAMIN, Walter. Obras escolhidas 3. São Paulo: Brasiliense, 2000 (1938)

BERMAN, Marshall. Tudo que é sólido desmancha no ar: a aventura da modernidade. São Paulo: Cia das Letras, 1986.

BERNHEIMER, Charles. "Linguistic Realism in Flaubert's 'Bouvard et Pécuchet'. in Novel. Vol. 7 no 2, winter, 1974. http://www.jstor.org/stable/1345094. Acessado em: 26 jun 2008.

BERTRAND, Denis. Caminhos da Semiótica literária. Bauru: Edusc, 2003.

. "De la topique à la figuration spatiale". in: Nouveaux Actes Sémiotiques.

Prépublications du séminaire, 2008 - 2009: Sémiotique de l'espace. Espace et signification. <http://revues.unilim.fr/nas/document.php?id=2759> Acesso em: 10 AGO 2010, 9:30.

BIASI, Pierre Marc de (org.), Carnets de Travail. Paris : 1988. 
Réference,

Gustave Flaubert: les secrets de "l'homme-plume. Paris: Hachettedebiasi.com/litterature/affichetext.php?src_texte=secrets_hommeplume.php\&rubriqu e=Flaubert $>$. Acessado em: 06 ago 2008.

"Flaubert : dynamique de la genèse" in Genesi, critica, edizione, (Atti del convegno internazionale di studi Scuola Normale Superiore di Pisa, 11-13 aprile 1996), Annali della Scuola Normale Superiore di Pisa, serie IV, Quaderni 1, Classe di lettere e Filosofia, Pisa 1998, 1999, pp. 87-102.

BIRNBAUM, Daniel. "Making Worlds", in: Catalogue, 53rd International Art Exhibition Fare Mondi // Making Worlds. Veneza: Marsilio, 2009.

BLANCHOT, Maurice. Le Livre à Venir. Paris : Gallimard, 1959.

. L'espace Littéraire. Paris : Gallimard, 1955.

BLOOM, Harold. A Angústia da Influência, uma teoria da poesia. Rio de Janeiro : Imago, 1973.

BORGES, Jorge Luis. Obras Completas (1923-1972). Buenos Aires: Emecé Editores 1974.

BORGES, Jorge Luis. Obras completas de Jorge Luis Borges. 1. ed. São Paulo: Globo, 1998. 3 v.

BOURDIEU, P. Les Règles de l'Art. Paris: Seuil, 1992.

Raisons Pratiques : Sur la théorie de l'action. Paris : Seuil, 1994.

BROMBERT, V. Flaubert. Paris : Éditions du Seuil, 1979.

BROOKS, Peter. Reading for the Plot - Design and Intention in Narrative. Cambridge: HUP, 1984.

. Realist Vision. New Haven: Yale University Press, 2005.

BROWN, Andrew. "Un assez vague Spinozisme" in: The Modern Language Review, Vol. 91, no 4, October, 1996. <http://www.jstor.org/stable//3733513>. Acessado em 26 jun 2008.

BURGESS, Anthony. On the Short Story. In: Les Cahiers de la nouvelle/Journal of the Short Story in English, $n^{\circ}$ 2, Université d'Angers, janvier 1984, pp. 31-47.

CALLEWAERT, Gustave. "Bourdieu, crítico de Foucault". in: Educação, Sociedade e Culturas. o 19. Porto: Faculdade de Psicologia e Ciências da Educação da U. PORTO (FPCEUP)/Edições Afrontamento, 2003.

CALIENDO, Luís Cláudio Kinker. Orelhas de elefante, olhos de coruja, dentes de javali: maravilhoso e descritivo em Yvain ou le Chevalier au Lion, de Chrétien de Troyes. Dissertação de Mestrado. 2009.

CALVINO, Italo. Seis propostas para o próximo milênio. São Paulo, Companhia das Letras, 1994.

CANDIDO, A. O Albatroz e o Chinês. Rio de Janeiro: Ouro sobre Azul, 2004. . Literatura e Sociedade. São Paulo: T. A. Queirós, 2000.

CARR, Nicholas. "Is Google making us stupid?" in: The Atlantic Monthly, Volume 301 No. 6, July/August 2008. <http://www.theatlantic.com/doc/200807/Google> Acessado em: 05 jun 2008.

CHESSEX, J. Flaubert ou le désert en abîme. Paris, Bernard Grasset, 1991.

COMPAGNON, Antoine. La troisième république des lettres. Paris: Seuil, 1983. . Le démon de la théorie. Paris: Seuil, 1992 (2001)

CRANEY, L. e Schwartz, V. R. O Cinema e a Invenção da Vida Moderna. São Paulo: Cossac \& Naify, 2001.

CULLER, Jonathan D. Flaubert: the uses of uncertainty. Ithaca: Cornell University Press, 1974. 
DANCOURT, Michele. Dédale \& Icare métamorphose d'un mythe. Paris: CNRS Editions, c2002.

DEBRAY-GENETTE, R. Flaubert à L'œuvre. Paris : Flammarion, 1980. . Métamorphoses du Récit. Paris: Seuil, 1988.

Travail de Flaubert, Paris: Seuil, 1983.

DELEUZE, Gilles. Différence et répétition. Paris: PUF, 1969. Lógica do sentido. São Paulo : Perspectiva, 2007 (1969).

DELEUZE, Gilles e GUATTARI, Felix. Mil Platôs. Vol. 5. São Paulo: Editora 34, 1997. DERRIDA, Jacques. L'écriture et la différence. Paris : Seuil, Tel Quel, 1967.

DES CARS, Jean e PINON, Pierre. Paris Haussmann - Le Pari d'Haussmann. Paris: Picard Éditeur, 1991.

DOMINGUES, Diana (Org.). A arte no século XXI: a humanização das tecnologias. São Paulo: Editora da Unesp, 1997.

DORD-CROUSLÉ, Stéphanie. "Savoir et ignorer dans Bouvard et Pécuchet de Gustave Flaubert", in. Balansard, Anne et al. Savoir et ignorer. Paris: Éditions Belin, 1999.

DOSSE, François. História do estruturalismo. Bauru: EDUSC, 2007. 2 vols. Trad. Álvaro Cabral.

DOUCHIN, Jacques-Louis. Sentiment de l'Absurde chez Gustave Flaubert. Paris: Lettres Modernes, 1970.

DUCHET, Claude. Écriture et desécriture de l'histoire dans Bouvard et Pécuchet. in: DEBRAY-GENETTE, Raymonde. Flaubert à l'œuvre. Paris : Flammarion, 1980.

DUQUETTE, Jean Pierre. Flaubert, ou L'architecture du vide; une lecture de L'éducation sentimentale. Montréal : Presses de l'Université de Montréal, 1972.

EAGLETON, Terry. Teoria da literatura: uma introdução. São Paulo: Martins Fontes,2003.

ECO, Umberto. A Obra Aberta. São Paulo: Perspectiva, 2008, 9aㅡ Ed. (1962).

ELLMANN, Richard e FEIDELSON Jr, Charles (ed.). The modern tradition. Nova lorque: Oxford University Press, 1973 (1965).

FOUCAULT, M. La Bilbliothèque Fantastique : à propos de la Tentation de Saint Antoine de Gustave Flaubert. Paris : Seuil, 1983.

. Les mots et les choses. Paris : Gallimard, 2007 (1966).

Archéologie du Savoir. Paris: Gallimard, 2005 (1969).

Cordeiro.

. O que é um Autor. Lisboa: Veja/Passagens, 1992. Tradução: Edmundo

FOURNIER, Louis. "Bouvard et Pécuchet, comédie de l'intelligence". The French Review. Special Issue, No. 6, Studies on the French Novel, (Spring, 1974), pp. 73-81. <http://www.jstor.org/stable/487536>. Acessado em: 26 jun 2008.

FRANCIS, Paulo. Trinta Anos esta Noite. São Paulo: Companhia das Letras, 1994.

FRYE, Northrop. O caminho crítico. São Paulo: Perspectiva, 1973.

Sobre Shakespeare. São Paulo: Edusp, 1999.

GAGNEBIN, Jeanne Marie. História e Narração em Walter Benjamin. São Paulo: Perspectiva, 1999.

GENETTE, Gerard. Figures. Paris: Seuil, 1966.

. Figures II. Paris: Seuil, 1969.

. Figures III. Paris: Seuil, 1972.

. L'œuvre de l'art. La relation esthétique. Paris: Seuil, 1972.

GIANNOTTI, J. A. "Introdução", in PORCHAT, O. Ciência e Dialética em Aristóteles.

São Paulo: Editora da UNESP, 2001.

GLISSANT, Édouard. Introduction à une poétique du Divers. Paris: Gallimard, 1996. 
GONCOURT, Edmont e GONCOURT, Jules. Germinie Lacerteux. Munique: Belenus, 2008.

HOBSBAWM, Eric J. A Era das Revoluções. São Paulo: Paz e Terra, 2007 (1977). . A Era do Capital. São Paulo: Paz e Terra, 2007 (1996).

HOCKE, Gustav R. Maneirismo: o mundo como labirinto. São Paulo: Perspectiva, 2005. (2) *

JACQUET, Claude e TOPIA, André (ed.). Scribble 2 - Joyce et Flaubert. Paris: Lettres Modernes/Minard, 1990.

JAMES, William. The Critical Muse. Londres: Penguin, 1987.

JORGE, Verónica G. Alucinação, memória e gozo místico. Dimensões dos manuscritos de "Un Cœur Simple" e "Hérodias" de Flaubert. Dissertação de mestrado. São Paulo, 2000.

. Como as mil peças de um jogo de escritura nos manuscritos de Flaubert. Tese de doutorado. São Paulo, 2003.

KENNER, Hugh. The Stoic Comedians : Flaubert, Joyce, Beckett. Londres : Dalkey Archive Press, 1962.

KENNETH, Joy (ed.). The age of marvelous. Hanover, New Hampshire: Dartmouth College, Hood Museum of Art, 1991. (Catálogo de exposição)

LEÃO, Lucia. O Labirinto da hipermídia - arquitetura e navegação no ciberespaço. 1. ed. São Paulo: lluminuras, 1999. 158 p.

LECLERC, Yvan. La spirale et le monument. Paris: Sedes, 1988.

LE JUEZ, Brigitte. Beckett avant la lettre. Paris: Bernard Grasset, 2007.

LODGE, David (ed.). Modern criticism and theory. Essex: Longman, 1988.

LUKÁCS, Teoria do Romance. São Paulo: Ed. Duas Cidades/Editora 34, 2000.

"Narrar ou descrever? Contribuição para uma discussão sobre o naturalismo e o formalismo". In: Ensaios sobre a literatura, Rio de Janeiro: Civilização Brasileira, 1965 (trad. Giseh Vianna Konder).

MACHADO, Arlindo. "Hipermídia: o labirinto como metáfora". In: DOMINGUES, Diana (Org.). A arte no século XXI: a humanização das tecnologias. São Paulo: Editora da Unesp, 1997.

MASSON, B. (org.), Flaubert et après.... Paris: Lettres Modernes Minard, 1984.

MEYER, Arno. A força da tradição: a persistência do Antigo Regime. São Paulo: Cia das Letras, 1990 (1981).

MIRECOURT, Eugène de. Monnier / Les Contemporains. Paris: Gustave Havard, 1857.

MONIER-BÉRENGUIER, Nadine. "Roland Barthes et le roman", in The French Review, vol. 59, no 5 (abr 1986). Carbondale (IL): American Association of Teachers of French, 1986.

NEEFS, Jacques e MOUCHARD, Claude. Flaubert. Paris: Balland, 1986.

NITRINI S. N. Literatura Comparada. São Paulo: Edusp, 2000.

PELLEGRINI. Florence. "Mais pourquoi m'a-t-elle fait ça !: la causalité dans Bouvard et Pécuchet de Gustave Flaubert". Tese de doutorado. <http://flaubert.revues.org/index591.html>. Acesso em 31 ago 2009.

PERRONE-MOISÉS, Leyla. "A educação escritural ou o outro Flaubert". In: Flores da escrivaninha. São Paulo: Cia. Das Letras, 1988, pp. 67-83.

PESSOA, Fernando. Pessoa. Fernando Pessoa - obras em prosa. Rio de Janeiro: Nova Aguilar, 1986.

PRIVATEER, Paul. "Contemporary literary theory: A thread through the labyrinth" in: Pacific Coast Philology. Vol. 18, oㅡ 1 / 2 (novembro/1983), p. 92-99. 
PROUST, Marcel - "À propos du style de Flaubert", in : Contre Sainte Beuve, suivi de Pastiches et Mélanges. Paris: Gallimard/Pléiade, 1971.

POUND, E. ABC of Reading. London : Faber and Faber, 1961.

POUND, E. A Arte da Poesia. Cultrix, São Paulo, 1988.

POYET, Thierry. Le Nihilisme de Flaubert. Paris : Éditions Kimé, 2000.

RABELAIS, François. Pantagruel e Gargântua. Belo Horizonte: Vila Rica, 1991. Trad.

David Jardim Júnior. p. 359-361.

READ, F. Pound/Joyce, the letters of Ezra Pound to James Joyce. New York: New Directions, 1966.

REED, Walter L. "The Problem with a Poetics of the Novel", in NOVEL: A Forum on Fiction, Vol. 9, No. 2 (Winter, 1976), pp. 101-113. Durhan (NC): Duke University Press, 1976. <http://www.jstor.org/stable/1345367>, acessado em: 9 fev 2009, 17:40. REES, Kate. "Une tortue avec des ailes: progressing in Flaubert's Bouvard et Pécuchet", in: French Studies, Vol. LXIII, No. 3, 271-282. Oxford : OUP, 2009.

RICE, Mary. "The Failure of Metaphor as an Historical Paradigm: Flaubert's 'Salammbô'”. In: Modern Language Studies. Vol. 20, no 1, winter, 1990. <http://www.jstor.org/stable/3195165>. Acessado em: 26 jun 2008.

RICHARD, Jean-Pierre. "Stendhal et Flaubert", in Littérature et sensation. Paris : Éditions du Seuil, 1970.

Seuil, 1954.

"La création de la forme chez Flaubert", in Littérature et sensation. Paris:

RICOEUR, Paul. A metáfora viva. São Paulo: Loyola, 2000.

ROBBE-GRILLET, Alain. Pour um Nouveau Roman. Paris: Minuit, 1959.

SALGUEIRO, Heliana Angotti (org.). Cidades capitais do século 19. São Paulo: Edusp, 2001.

SARRAUTE, Nathalie. CEuvres. Paris: Gallimard / Plêiade, 1996.

SARTRE, Jean-Paul. Que é a Literatura. São Paulo: Ática, 1989 (1948). Tradução: Carlos Felipe Moisés.

SCHEHR, R. "Flaubert's failure", in UNWIN, Timothy. The Cambridge companion to Flaubert. Cambridge: CUP, 2004.

SCHAVELBERG, Sophie. Bouvard et Pécuchet. Rosny: Bréal, 1999.

SÉGINGER, G. Flaubert : Une étique de l'art pur. Paris : Sedes, 2000.

1997.

Naissance et métamorphoses d'un écrivain. Paris: Honoré Champion,

."Forme romanesque et savoir. Bouvard et Pécuchet et les sciences

naturelles". In: Revue Flaubert $\mathrm{n}^{\circ}$ 4, $2004 . \quad<$ http://flaubert.univrouen.fr/revue/revue4/02seginger.pdf> Acesso em: 2 ago 2010, 16:38

SPITZER, L. Études de Style. Paris: Gallimard, 1988.

STAROBINSKI, Jean. La relation critique. Paris: Gallimard,xxxx.

THIBAUDET, Albert. Gustave Flaubert. Paris: Gallimard, 1982.

TILBY, Michael. "Flaubert's place in literary history", in UNWIN, Timothy. The Cambridge companion to Flaubert. Cambridge: CUP, 2004.

TITAN Jr. S. Ares de Romance: Realismo e gêneros literários nos três contos de Gustave Flaubert. Tese de Doutorado. São Paulo, 2003.

TODOROV, Tzvetan. As Estruturas Narrativas. São Paulo: Perspectiva, 2008, 5ae ed.

TON-THAT, Thanh-Vân. Bouvard et Pécuchet: une odysée de la bêtise. Paris:

Éditions du Temps, 1999.

UNWIN, Timothy. The Cambridge companion to Flaubert. Cambridge: CUP, 2004.

VALÉRY, Paul. "Tel quel", CEuvres II. Paris : Gallimard,1960. 
"La Tentation de (saint) Flaubert", in OEuvres, vol. 1. Paris: Gallimard, 1957. WETHERILL, P. M. Flaubert et la Création Littéraire. Paris: Librairie Nizet, 1964.

WILSON, Edmund. "The politics of Flaubert", in The triple thinkers. New York: Galaxy Books/Oxford UP, 1963.

ZOLA, Émile. La Curée. Paris: Garnier-Flammarion, 1970. 


\section{ANEXO I}

CD com exemplos de composições musicais representativas dos emprego de repetições.

1. Philip Glass: Dance II

2. Steve Reich: Four Organs

3. John Cage: Williams mix

4. Gamelão balinês

5. Ornette Coleman: Three wishes 